\title{
Espécies sentinelas para a Mata Atlântica: as conseqüências epidemiológicas da fragmentação florestal no Pontal do Paranapanema, São Paulo
}

Tese apresentada ao Programa de Pós-Graduação em Epidemiologia Experimental e Aplicada às Zoonoses da Faculdade de Medicina Veterinária e Zootecnia da Universidade de São Paulo para obtenção do título de Doutor em Ciências

Departamento:

Medicina Veterinária Preventiva e Saúde Animal

Área de concentração:

Epidemiologia Experimental e Aplicada às Zoonoses

Orientador:

Prof. Dr. Fernando Ferreira

São Paulo 
Autorizo a reprodução parcial ou total desta obra, para fins acadêmicos, desde que citada a fonte.

DADOS INTERNACIONAIS DE CATALOGAÇÃO-NA-PUBLICAÇÃO

(Biblioteca Virginie Buff D’Ápice da Faculdade de Medicina Veterinária e Zootecnia da Universidade de São Paulo)

Nava, Alessandra Ferreira Dales

Espécies sentinelas para a Mata Atlântica: as conseqüências epidemiológicas da fragmentação florestal no Pontal do Paranapanema, São Paulo / Alessandra Ferreira Dales Nava. - São Paulo : A. F. D. Nava, 2008.

$147 \mathrm{f}$ : : il.

Tese (doutorado) - Universidade de São Paulo. Faculdade de Medicina Veterinária e Zootecnia. Departamento de Medicina Veterinária Preventiva e Saúde Animal, 2008.

Programa de Pós-Graduação: Epidemiologia Experimental e Aplicada às Zoonoses.

Área de concentração: Epidemiologia Experimental e Aplicada às Zoonoses.

Orientador: Prof. Dr. Fernando Ferreira.

1. Medicina da conservação. 2. Medicina preventiva. 3. Fragmentação florestal. 4. Saúde pública. 5. Doenças infecciosas. I. Título. 


\title{
PARECER DA COMISSÃO DE BIOÉTICA
}

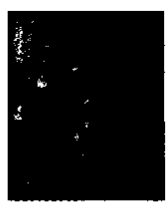

\author{
UNIVERSIDADE DE SÃO PAULO \\ Faculdade de Medicina Veterinária e Zootecnia \\ Cidade Universitária "Armando de Salles Oliveira"
}

Comissão de Bioética

\section{CERTIFICADO}

Certificamos que o Projeto intitulado "Espécies sentinelas para a mata atlântica: as conseqüências epidemiológicas da fragmentação florestal no Pontal do Paranapanema-SP", protocolo n'630/2005, utilizando 130 catetos e queixadas, sob a responsabilidade do Prof. Dr. Fernando Ferreira, está de acordo com os princípios éticos de experimentação animal da Comissão de Bioética da Faculdade de Medicina Veterinária e Zootecnia da Universidade de São Paulo e foi aprovado "ad referendun".

(We certify that the Research "Sentinel species: conservation and health in atlantic Forest fragments, Brazil", protocol number 630/2005, utilizing 130 animals, under the responsibility of Prof. Dr. Fernando Ferreira, agree with Ethical Principles in Animal Research adopted by Bioethic Commission of the Faculty of Veterinary Medicine and Zootechny of University of São Paulo and was approved "ad referendun", meeting).

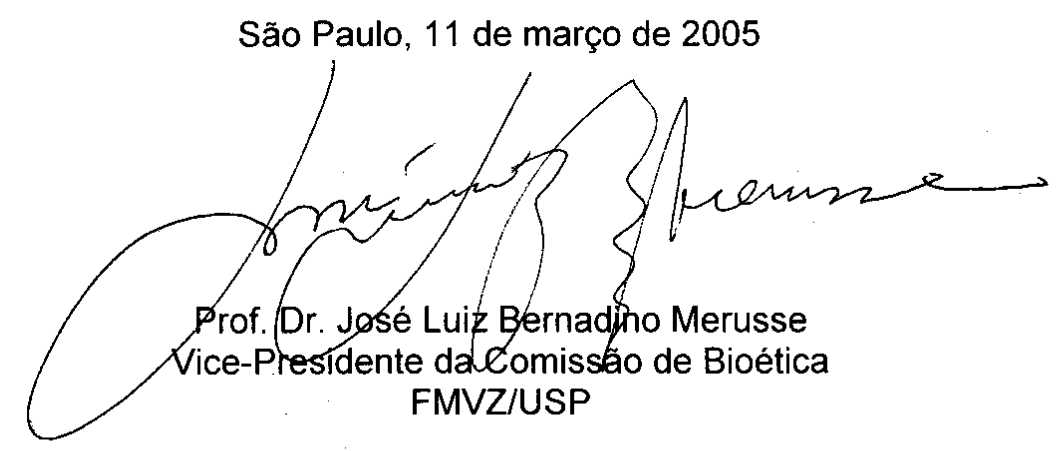




\section{FOLHA DE AVALIAÇÃO}

Nome: NAVA, Alessandra Ferreira Dales

Título: Espécies sentinelas para a Mata Atlântica: as conseqüências epidemiológicas da fragmentação florestal no Pontal do Paranapanema, São Paulo

Tese apresentada ao Programa de Pós-Graduação em Epidemiologia Experimental e Aplicada às Zoonoses da Faculdade de Medicina Veterinária e Zootecnia da Universidade de São Paulo para obtenção do título de Doutor em Ciências

Data; I l

Banca Examinadora

Prof. Dr.

Assinatura:

Prof. Dr.

Assinatura:

Prof. Dr.

Assinatura:
Instituição:

Julgamento:
Instituição:

Julgamento:
Instituição:

Julgamento: 


\section{DEDICATÓRIA}

Dedico esta tese a todos os animais silvestres do Pontal do Paranapanema, e toda sua biodiversidade, verdadeiros sobreviventes em um mundo antropocêntrico e ganancioso; às pessoas que lutaram e lutam para a conservação da biodiversidade brasileira; aos meus bichos maravilhosos e companheiros Nina, Juju e Izidro. E para Katherine, Morgs e Chiara para sempre no meu coração. 


\section{AGRADECIMENTOS}

À minha mãe Rosa Nava, jornalista e pesquisadora, que com certeza me inspirou para o caminho da pesquisa, ao meu pai e minhas irmãs Déa e Dri, que certamente nunca entenderam o que faço.

A Luara por existir...

Aos meus, avós Enzo e Caçula, por me cederem sua casinha.

Ao Rodrigo pelo carinho e companheirismo na reta final da tese.

Ao Prof. Fernando Ferreira pela sua orientação e amizade nos momentos difíceis.

Ao Laury Cullen Junior que me iniciou nos caminhos da preservação ambiental, e me ensinou que a vida deve ser enxergada da lua...

Aos amigos Fernando Pacheco, Adriana Cortez e Marcos Heinemann pela confiança, apoio, carinho e orientação.

A Patricia Marques Ferreira e Monica Fagundes pelas muitas ajudinhas e apoio.

Ao Sr. Cícero Joaquim Sebastião, assentado da Ribeirão Bonito pelo apoio constante, excelente trabalho de campo e profissionalismo.

A Terezinha e família pelo carinho e aconchego no assentamento Tucano.

À amiga Taninha por sempre me ajudar na parte burocrática da pós...

A Alonso Aguirre, pela amizade, orientação e gentil doação dos kits diagnósticos para leucemia felina e imunodeficiência felina e, principalmente, por acreditar em mim.

A Aleksei Mac Durian pela grande amizade e carinho.

À Fapesp pelo apoio financeiro.

A Marcello Schiavo Nardi pela imensa ajuda no trabalho de campo e amizade.

A Daniela Ribeiro, Camila, Fernanda e Fátima Andreoni pela acolhida em muitas noites, enquanto realizava meus créditos.

Aos funcionários do Laboratório de Zoonoses Bacterianas do Departamento de Medicina Veterinária Preventiva e Saúde Animal da Faculdade de Medicina Veterinária e Zootecnia da Universidade de São Paulo (VPS/FMVZ/USP), pela realização da sorologia e tentativas de isolamento de leptospirose e brucelose, especialmente para a Zenaide e Gisele. 
À equipe do laboratório de Doenças Parasitárias do Departamento de Medicina Veterinária Preventiva e Saúde Animal da Faculdade de Medicina Veterinária e Zootecnia da Universidade de São Paulo (VPS/FMVZ/USP), especialmente ao professor Marcelo Labruna.

Aos professores do VPS, em especial aos professores Silvio Vasconcellos, José Soares e Evelise.

A Jucélia, Danival e demais funcionários do VPS pelo apoio.

À Biovet, especialmente ao José Domingues de Ramos Filho por todo auxílio na realização do sorodiagnóstico para cinomose.

Aos padrinhos mágicos, Martinho, Renata e Atito, sempre ao meu lado.

A todos os estagiários que me auxiliaram ao longo deste estudo, especialmente a Anaiá Paixão Sevá.

A Elza e Fátima da Biblioteca da Faculdade de Medicina Veterinária e Zootecnia da Universidade de São Paulo.

Aos amigos Fabíola, Wanessa e Antonio pelos momentos de descontração compartilhados... 


\section{RESUMO}

NAVA, A. F. D. Espécies sentinelas para a Mata Atlântica: as consequências epidemiológicas da fragmentação florestal no Pontal do Paranapanema, São Paulo. [Sentinel species for Atlantic Rainforest: epidemiological consequences of forest fragmentation in Pontal do Paranapanema, São Paulo]. 2008. 147 f. Tese (Doutorado em Ciências) - Faculdade de Medicina Veterinária e Zootecnia, Universidade de São Paulo, São Paulo, 2008.

A conservação da biodiversidade e de ecossistemas saudáveis é extremamente necessária para a saúde dos indivíduos, das populações humanas e das demais espécies encontradas na natureza. Como conseqüência desses múltiplos estresses ambientais estão certas doenças emergentes, a desestabilização de cadeias tróficas e os efeitos deletérios na saúde de populações silvestres e na ecologia dos habitats fragmentados. O objetivo principal deste estudo foi estudar as conseqüências epidemiológicas da fragmentação florestal nas populações de animais domésticos, felinos silvestres e taiassuídeos presentes no Parque Estadual Morro do Diabo e fragmentos florestais próximos, intencionando determinar o padrão de ocorrência de doenças na população silvestre. Para isso foram capturados e tiveram amostras coletadas: 39 catetos (Tayassu tajacu), 61 queixadas (Tayassu peccari), 2 jaguatiricas (Leopardus pardalis), 2 onças pardas (Puma concolor), 8 onças pintadas (Panthera onca), e 100 Rattus rattus bem como os seguintes animais domésticos: 782 bovinos, 214 caninos, 193 eqüinos, 108 ovinos, 97 suínos e 17 gatos domésticos do entorno do PEMD e fragmentos florestais. Para os animais silvestres e domésticos amostrados, com exceção dos gatos domésticos foi realizado sorodiagnóstico para Leptospira spp (MAT) e Brucella spp. (rosa bengala e fixação de complemento) e tentativas de isolamento para Leptospira spp e Brucella spp. ; para os caninos domésticos, felídeos silvestres e taiassuídeos foi realizado sorodiagnóstico para cinomose (soroneutralização); para felídeos silvestres e felinos domésticos foi realizado sorodiagnóstico para imunodeficiência felina e leucemia felina (ELISA indireto). Dentre os felídeos selvagens e domésticos, nenhum animal foi reagente para imunodeficiência felina e leucemia felina; também não foi identificado animal reagente para cinomose entre os felídeos silvestres e taiassuídeos, porém os caninos domésticos 12 de 200 animais foram reagentes; para brucelose 7 queixadas, 1 cateto, 13 bovinos, 3 cães e 1 onça pintada foram 
reagentes, as outras espécies como ovinos, suínos e equinos não foram reagentes; para leptospirose 18 queixadas, 4 catetos, 1 onça pintada, 322 bovinos, 12 ovinos, 15 suínos e 64 equinos. As tentativas de isolamento para leptospirose e brucelose foram inconclusivas. Os resultados indicam que os animais silvestres e os animais domésticos do entorno das florestas foram expostos a alguns agentes pesquisados. É urgente um programa de extensionismo rural visando o incremento da saúde animal doméstica que vive no entorno do PEMD e fragmentos florestais. As altas prevalências de leptospirose em animais domésticos e silvestres, e outras doenças infecto contagiosas que possam estar presentes no estoque animal doméstico da região devem ser minimizadas com um trabalho de medicina preventiva nesta população. A presença de zoonoses como a leptospirose e brucelose nos animais domésticos são um risco de saúde pública para os proprietários rurais. Um programa de conscientização deve ser realizado na região perante os resultados desse estudo, envolvendo saúde pública, controle populacional de cães e gatos, e vacinação dos animais domésticos. Na elaboração dos planos de manejo das UCs deve ser incluído diagnóstico da fauna selvagem a patógenos, e conhecer o risco existente de doenças infectocontagiosas nos animais domésticos que vivem no entorno das UCs.

Palavras-chave: Medicina da conservação. Medicina preventiva. Fragmentação florestal. Saúde pública. Doenças infecciosas. 
ABSTRACT

NAVA, A. F. D. Sentinel species for Atlantic Rainfores: epidemiological consequences of forest fragmentation in Pontal do Paranapanema, São Paulo. [Espécies sentinelas para a Mata Atlântica: as consequências epidemiológicas da fragmentação florestal no Pontal do Paranapanema, São Paulo]. 2008. 147 f. Tese (Doutorado em Ciências) - Faculdade de Medicina Veterinária e Zootecnia, Universidade de São Paulo, São Paulo, 2008.

The biodiversity conservation and healthy ecossistems are extremely necessary for human health and wild animal species. As a consequence of environmental stresses are emerging diseases, trofic disrupten and harmful effects in the wildlife health population and fragmented landscape ecology. The main objective of this study is to study relationships between forest fragmentation in domestic stock, white-lipped, collared peccary, wild felides in Morro do Diabo state Park and forest fragments, to determining the pattern of disease occurrence in the wildlife population. 39 collared peccaries (Tayassu tajacu), 61 white lipped peccaries (Tayassu peccari), 2 ocelots (Leopardus pardalis), 2 pumas (Puma concolor), 8 jaguars (Panthera onca), e 100 rats (Rattus rattus) as well: 782 cattle, 214 dogs, 193 horses, 108 sheeps, 97 pigs e 17 cats surrounded MDSP and forest fragments. Serological tests were conducted for wild animals and domestic stock for Leptospira spp (MAT) e Brucella spp. (rose Bengal test, standard serum agglutination test, complement fixation) and cultures for Leptospira spp e Brucella spp..Serological tests for canine distemper (SN) were conducted for dogs, wild felides and peccaries; FIV and FelV were conducted for wild felides and cats (ELISA). Among wild felides and cats were no exposure for FIV and FeLV, as well dogs, wild felides, peccaries were no positives for canine distemper, however 12 of 200 dogs tested for canine distemper were serologically positive; for brucellosis 7 white lipped peccaries, 1 collared peccary, 13 cattle, 3 dogs, 1 jaguar were serologically positive instead of pigs, horses and sheeps, were serologically negative. For Leptospira spp. 18 white lipped peccaries, 4 collared peccaries, 1 jaguar, 322 cattle, 12 sheeps, 15 pigs, 64 horses were serologically positive instead the rats were all serologically negatives. Leptospirosis and brucellosis isolation were inconclusive. These results demonstrate that wild animals and domestic animals were exposed by these pathogens. An outreach program is necessary to improve the livestock health surround the forest fragments and the state Park. High levels of 
exposure of leptospirosis and brucellosis found in wild animals and livestock indicates that these pathogens are in contact with the animal population. A preventive medicine work is urgent in this area. The presence of zoonosis such as leptospirosis and brucellosis in the domestic stock are a threat to human health. An outreach program must be develop in the region facing these results and should involve public health, dogs and cats population vaccination and sterilization, vaccination of livestock. The management plans for protected areas should include screening for diseases in wild animals and domestic stock, to the acquire knowledge of infectious diseases risk nearby protected areas.

Key words: Conservation medicine. Preventive medicine. Forest fragmentation. Public health. Infectious diseases 


\section{LISTA DE MAPAS}

Mapa 1- Distribuição de eqüinos no entorno dos fragmentos florestais do Pontal do Paranapanema.

Mapa 2- Distribuição de bovinos nos fragmentos florestais do Pontal do

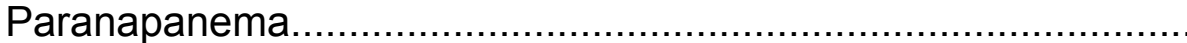

Mapa 3- Distribuição de suínos no entorno dos fragmentos de floresta do Pontal do Paranapanema.

Mapa 4- Distribuição de cães no entorno dos fragmentos de floresta do Pontal do Paranapanema.

Mapa 5- Local de amostragem de cães e onças pintadas amostrados para cinomose no Pontal do Paranapanema.

Mapa 6- Cães amostrados para cinomose reagentes e não reagentes......

Mapa 7- Locais de amostragem dos felinos domésticos e silvestres 


\section{LISTA DE FIGURAS}

Figura 1- $\quad$ Região do Pontal do Paranapanema................................... 21

Figura 2- Remanescentes florestais no Pontal do Paranapanema circundados por assentamentos da reforma agrária.

Figura 3- $\quad$ Catetos capturados nos fragmentos agrupados por tamanho.....

Figura 4- Queixadas capturados nos fragmentos florestais do Pontal do Paranapanema

Figura 5- $\quad$ Faixa etária dos catetos capturados no Pontal do Paranapanema

Figura 6- $\quad$ Faixa etária dos queixadas capturados no Pontal do Paranapanema

Figura 7- $\quad$ Animais domésticos amostrados no Pontal do Paranapanema...

Figura 8- Quantidade de bovinos no entorno do PEMD e amostrados......

Figura 9- Quantidade de suínos, ovinos, eqüinos e cães no entorno do.

PEMD - quantidade de animais domésticos amostrados no entorno do PEMD

Figura 10- Quantidade de animais no entorno de fragmentos pequenos e quantidade de animais domésticos amostrados.

Figura 11- Quantidade de bovinos no entorno dos pequenos fragmentos de mata e numero de animais amostrados.

Figura 12- Quantidade de suínos, ovinos, eqüinos e cães no entorno e animais domésticos amostrados no entorno dos fragmentos grandes.

Figura 13- Quantidade de bovinos e número de animais amostrados no entorno dos remanescentes de mata Tucano, Ponte Branca, Água Sumida e Santa Maria (fragmentos grandes)...............

Figura 14- Queixadas amostrados no Pontal do Paranapanema mostrando quantidade de indivíduos reagentes e não reagentes para leptospirose nos grupos de fragmentos. 
Figura 15- Catetos amostrados no Pontal do Paranapanema mostrando quantidade de indivíduos reagentes e não reagentes para leptospirose nos diferentes grupos de fragmentos.

Figura 16- Felídeos reagentes e não reagentes para leptospirose.

Figura 17- Bovinos reagentes e não reagentes para leptospirose nos diferentes grupos dos fragmentos de estudo

Figura 18- Caninos reagentes e não reagentes para leptospirose

Figura 19- Ovinos reagentes e não reagentes para leptospirose nos diferentes grupos.

Figura 20- Suínos reagentes e não reagentes para leptospirose nos diferentes grupos.

Figura 21- Equinos reagentes e não reagentes para leptospirose nos diferentes grupos.

Figura 22- Prevalência de leptospirose em taiassuídeos provenientes de fragmentos pequenos e animais e domésticos de seus entornos

Figura 23- Prevalência de leptospirose em taiassuídeos provenientes de fragmentos grandes e animais domésticos de seus entornos....

Figura 24- Prevalência de leptospirose em taiassuídeos provenientes do PEMD e animais domésticos de seu entorno.

Figura 25- Queixadas amostrados no PEMD, fragmento Ponte Branca (fragmento grande) e Santa Mônica (fragmento pequeno) para

Figura 26- Catetos amostrados para brucelose.

Figura 27- Bovinos reagentes para brucelose no entorno dos diferentes fragmentos florestais.

Figura 28- Cães reagentes para brucelose nos diferentes fragmentos florestais.

Figura 29- Bovinos amostrados no entorno de PEMD e taiassuídeos amostrados no PEMD reagentes e não reagentes para brucelose. 


\section{LISTA DE QUADROS}

Quadro 1- Algumas doenças encontradas em populações silvestres de queixadas (T. pecari) e catetos (T. tajacu) no sudoeste Norte Americano, América Central e do Sul

Quadro 2- Métodos diagnósticos empregados neste estudo.

Quadro 3- Relação das variantes sorológicas de leptospiras empregadas como antígenos para a realização da soroaglutinação microscópica

Quadro 4- Índices de riqueza de carrapatos coletados em queixadas em três diferentes fragmentos florestais.

Quadro 5- Indices de riqueza de carrapatos coletados em catetos em três diferentes fragmentos florestais.

Quadro 6- Medida de Similaridade de Jaccard entre os carrapatos coletados em catetos nas diferentes áreas.

Quadro 7- Medida de Similaridade de Jaccard entre os carrapatos coletados em queixadas nas diferentes áreas.

Quadro 8- Índices de riqueza de endoparasitas coletados em catetos em três diferentes fragmentos florestais.

Quadro 9- Índices de riqueza de endoparasitas coletados em queixadas em três diferentes fragmentos florestais

Quadro 10- Medida de Similaridade de Jaccard entre os endoparasitas coletados em catetos nas diferentes áreas.

Quadro 11- Medida de Similaridade de Jaccard entre os endoparasitas coletados em queixadas nas diferentes áreas.

Quadro 12- Titulação para cinomose, ponto de corte 1:16.

Quadro 13- Sorovares mais prováveis em animais silvestres nos três grupos de fragmentos

Quadro 14- Sorovares mais prováveis em animais domésticos nos três grupos de fragmentos 


\section{LISTA DE ABREVIATURAS E SIGLAS}

as

at

ia isolamento do agente

id imunofluorescência direta

IDH-M Índice de desenvolvimento humano

ha hectares

me anticorpos teciduais

PEMD Parque Estadual Morro do Diabo

PNUD Programa das Nações Unidas para o Desenvolvimento

UC's Unidades de Conservação 


\section{SUMÁRIO}

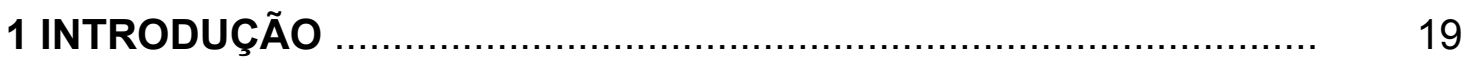

2 REVISÃO DE LITERATURA............................................................ 24

2.1 TAIASSUÍDEOS BRASILEIROS.................................................. 24

2.2 ONÇAS PINTADAS, ONÇAS PARDAS E JAGUATIRICAS............... 27

2.3 AGENTES PATOGÊNICOS E SUA OCORRÊNCIA EM FELÍDEOS

SELVAGENS E TAIASSUÍDEOS................................................ 27

2.3.1 Vírus da imunodeficiência felina (FIV) e leucemia felina (FELV)... $\quad 28$

2.3.2 Vírus da cinomose canina (CDV).............................................. 29

2.3.3 Leptospirose ........................................................................ 30

2.3.4 Brucelose ........................................................................ 32

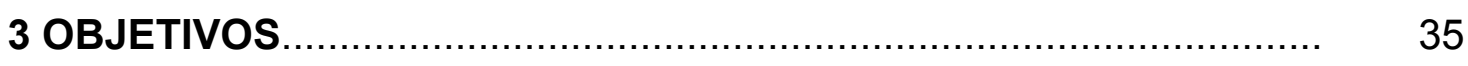

3.1 OBJETIVO PRINCIPAL............................................................. 35

3.2 OBJETIVOS ESPECÍFICOS......................................................... 35

4 MATERIAL E MÉTODOS............................................................... 37

4.1 ÁREAS ESPECÍFICAS DE ESTUDO ......................................... 37

4.2 COLETA DE AMOSTRAS PARA TAÍASSUÍDEOS........................... 38

4.3 COLETA DE AMOSTRA DE FELÍDEOS........................................ 40

4.4 COLETA DE AMOSTRAS DOS ANIMAIS DOMÉSTICOS................. 40

4.5 METODOLOGIA DE PROVAS SOROLÓGICAS E ISOLAMENTO

DE AGENTES INFECCIOSOS................................................. 41

4.6 AVALIAÇÃO DO PARASITISMO (CARRAPATOS E

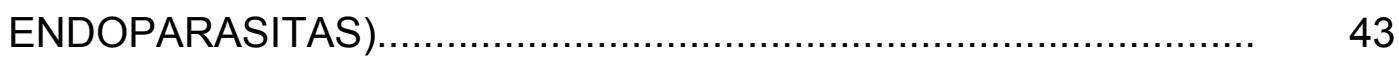

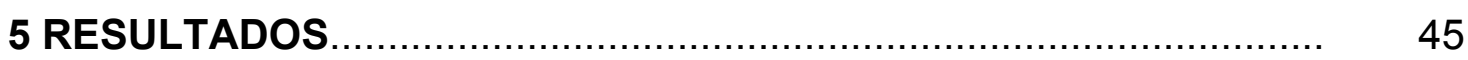

5.1 CARACTERÍSTICAS ECOLOGICAS DOS TAIASSUÍDEOS............. 45

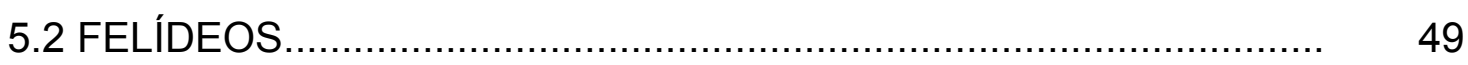

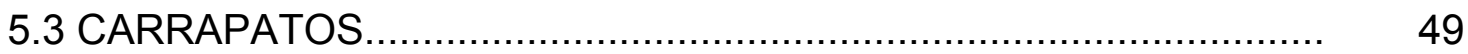

5.4 ENDOPARASITAS …......................................................... 51

5.5 ANIMAIS DOMÉSTICOS............................................................ 53

5.5.1 Animais domésticos do entorno do PEMD.................................. 54

5.5.2 Animais domésticos do entorno dos Fragmentos pequenos........ 56 
5.5.3 Animais domésticos do entorno dos Fragmentos grandes............ 58

5.5.4 Mapas da distribuição de animais domésticos............................. 60

5.6 CINOMOSE.................................................................. 64

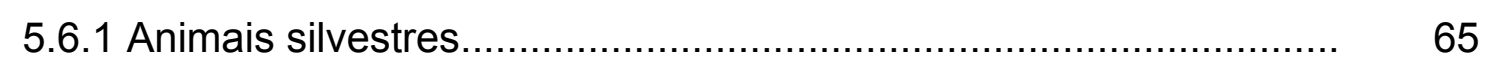

5.6.2 Animais domésticos........................................................... 66

5.7 LEPTOSPIROSE.............................................................. 68

5.7.1 Animais silvestres............................................................ 69

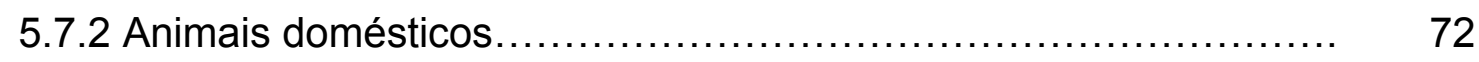

5.7.3 Animais domésticos e animais silvestres...................... 76

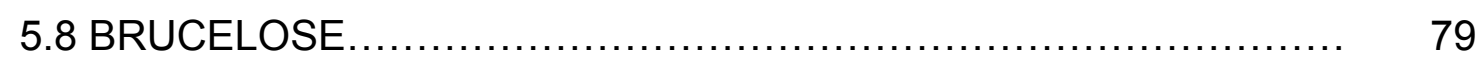

5.8.1 Animais silvestres......................................... 79

5.8.2 Animais domésticos.......................................................... 80

5.8.3 Animal doméstico e silvestre.................................... 82

5.9 IMUNODEFICIÊNCIA FELINA E LEUCEMIA FELINA................... 84

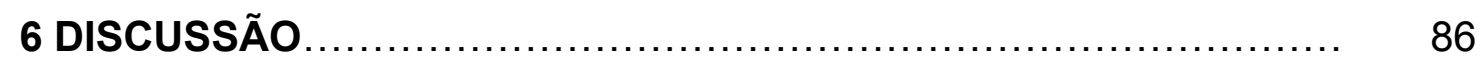

6.1 CARACTERÍSTICAS ECOLÓGICAS DOS FELÍDEOS E

TAIASSUÍDEOS ............................................................... 86

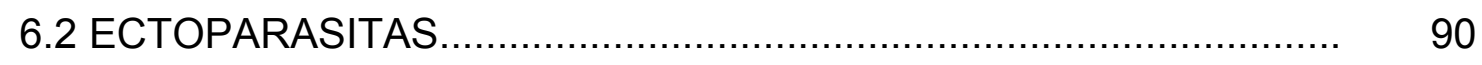

6.3 ENDOPARASITAS ............................................................... 93

6.4 CARACTERÍSTICAS DE MANEJO DOS ANIMAIS DOMÉSTICOS

NO ENTORNO DOS DIFERENTES GRUPOS DE FRAGMENTOS.. 95

6.5 CINOMOSE.................................................................... 96

6.6 LEPTOSPIROSE......................................................... 98

6.7 BRUCELOSE............................................. 102

6.8 IMUNODEFICIÊNCIA FELINA E LEUCEMIA FELINA.................. 104

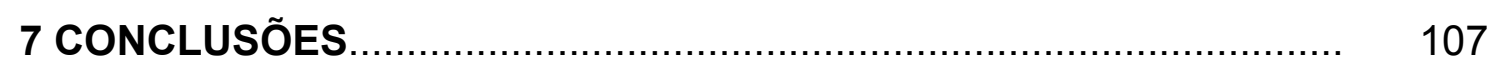

REFERÊNCIAS ................................................................ 110

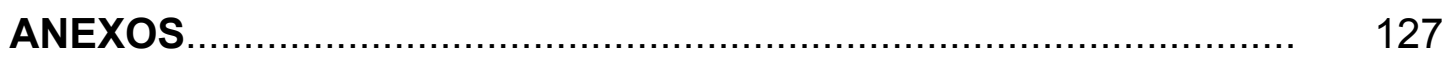

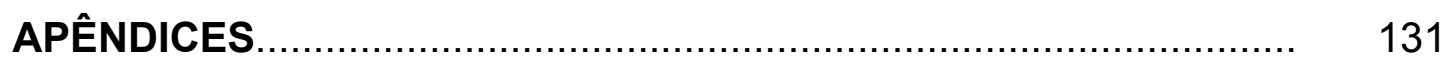




\section{INTRODUÇÃO}

O papel das doenças, como um importante fator para a sobrevivência das espécies, esteve sempre atrelado às mudanças antrópicas em escalas local, regional e global, com impactos diretos e indiretos na saúde dos animais (WOODROFFE, 1999). Essas mudanças incluem, por exemplo, a explosão demográfica da população mundial, a fragmentação e a degradação dos habitats, a caça predatória, o isolamento de espécies e populações silvestres, o aumento da proximidade entre as comunidades humanas (e seus animais domésticos) e as populações de animais silvestres. Como conseqüências desses múltiplos estresses ambientais estão: o aparecimento de doenças emergentes, a desestabilização de cadeias tróficas e os efeitos deletérios na saúde de populações silvestres, de animais de produção, que vivem próximos a florestas e na ecologia dos habitats fragmentados (HOLMES, 1996; CALEY E HONE, 2004).

Algumas espécies animais podem funcionar como verdadeiros "termômetros", ajudando a monitorar a saúde dos ecossistemas. Assim, o conceito de espécies sentinelas - aquelas que por refletirem as perturbações do meio ambiente podem servir de indicadores da conservação do ecossistema - está cada vez mais sendo utilizado na união entre a medicina veterinária e a biologia da conservação (DEEN et al., 2001; AGUIRRE et al., 2002).

Estas espécies animais podem ser utilizadas em levantamentos rápidos sobre os impactos ambientais e em monitoramentos de longo prazo com o objetivo de acompanhar e avaliar a preservação ou degradação dos ecossistemas estudados. Dessa forma, são essenciais e emergenciais, levantamentos que utilizem espécies sentinelas, ajudando a esclarecer aspectos ecológicos e sanitários dessas populações animais, os quais certamente contribuirão para o entendimento da dinâmica das paisagens fragmentadas, da conservação dos ecossistemas e dos recursos naturais. Neste sentido, este estudo tem como objetivo principal a utilização de ungulados (queixadas e catetos) e felinos selvagens (onças pintadas, pardas e jaguatiricas) como espécies sentinelas no monitoramento da saúde da Mata Atlântica do Interior do Estado de São Paulo. A escolha dessas espécies se deve a características ecológicas inerentes. No caso de catetos e queixadas, são animais que exploram bastante o entorno (roças de cana, mandioca) e que vivem em grupos, 
o que propicia maior chance de adquirirem doenças infectocontagiosas. Os felídeos apresentam extensa área de uso e são predadores, entrando em contato com diversas espécies de animais selvagens e espécies domésticas.

Uma das grandes dificuldades encontradas por profissionais da Biologia da Conservação é a de promover o elo existente entre biodiversidade e o bem estar da humanidade. Há uma evidente necessidade de se unir disciplinas e profissionais de várias áreas que, historicamente, não haviam demonstrado muita interação, para se obter respostas mais efetivas às questões sócio-ambientais emergentes. Um recente e estimulante esforço vem ocorrendo entre a Biologia da Conservação, a Medicina Veterinária e a Medicina Humana que, ao se juntarem, estão promovendo uma única disciplina: "A Medicina da Conservação". Este estudo tem como denominador comum a saúde, considerada de maneira mais ampla. Esse forte elo entre a biologia da conservação e a saúde das populações humanas e animais pode funcionar como uma nova ferramenta e contribuir com políticas públicas e sanitárias substanciais para promover a saúde dos animais de produção e defender a conservação da biodiversidade em nosso planeta.

A tese refere-se à região do Pontal do Paranapanema, no extremo oeste do Estado de São Paulo (Figura 1). As bacias do rio Paraná, a noroeste, e do Paranapanema, ao sul, correspondem aos limites dessa região com os Estados de Mato Grosso do Sul e Paraná, respectivamente. Os municípios que fazem parte da região são: Teodoro Sampaio, Rosana, Euclides da Cunha Paulista, Marabá Paulista e Presidente Epitácio. Em 1991, o índice de desenvolvimento humano (IDH-M) para a região era de 0.718 . Seguindo a classificação do PNUD, o Pontal do Paranapanema está entre as regiões consideradas de médio desenvolvimento humano (IDH entre 0,50 e 0,80) (PNUD, 2006). 


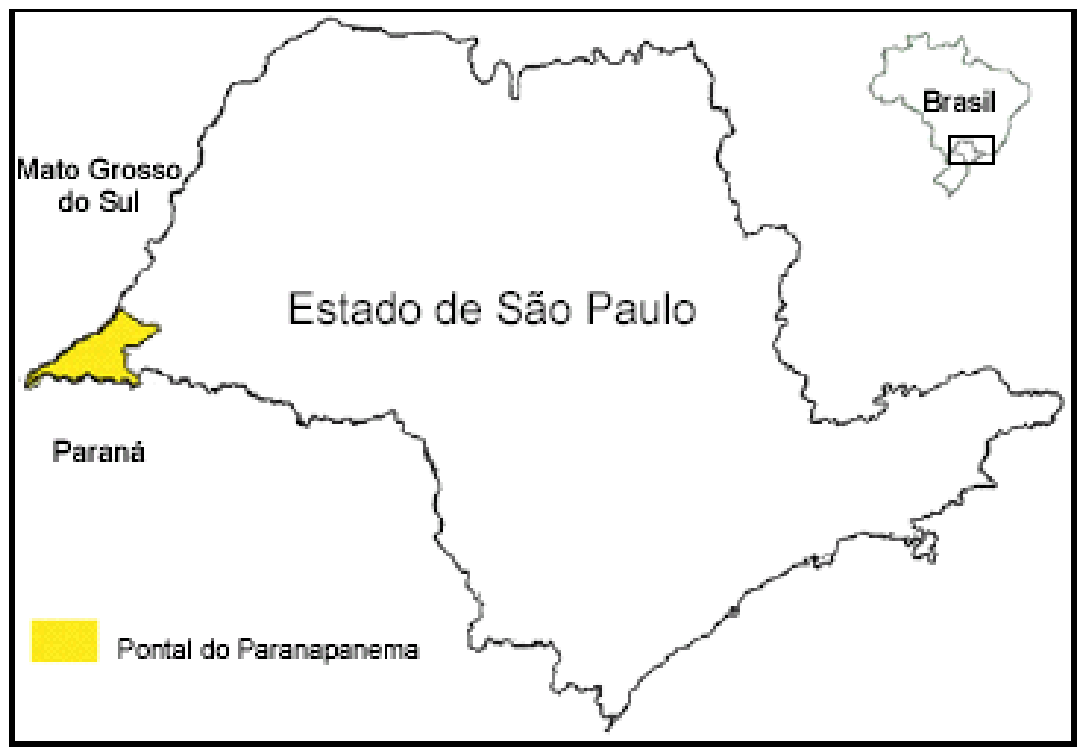

Figura 1 - Região do Pontal do Paranapanema, extremo oeste do Estado de São Paulo

Em 1942, o governo do Estado de São Paulo criou uma unidade de conservação chamada "Grande Reserva do Pontal do Paranapanema", para proteger 247.000 ha de Mata Atlântica (DITT, 2002). Durante as cinco décadas seguintes, quando a região ficou marcada por constantes conflitos fundiários, as terras dessa reserva foram ocupadas e convertidas em grandes propriedades rurais. Sua cobertura florestal foi substituída por pastagens para pecuária extensiva e por plantios de cana-de-açúcar. Atualmente, os fragmentos de mata remanescentes totalizam 21.000 ha e juntamente com os 36.500 ha de floresta do Parque Estadual Morro do Diabo, que é vizinho à Grande Reserva do Pontal do Paranapanema, são considerados os últimos refúgios da fauna e da flora, incluindo espécies ameaçadas como o mico-leão-preto e a onça-pintada (Figura 2). Hoje, uma nova dinâmica de ocupação tem levado a uma transformação na paisagem regional, onde vários fragmentos florestais estão sendo circundados e pressionados por assentamentos rurais da reforma agrária (NAVA et al., 2004). 


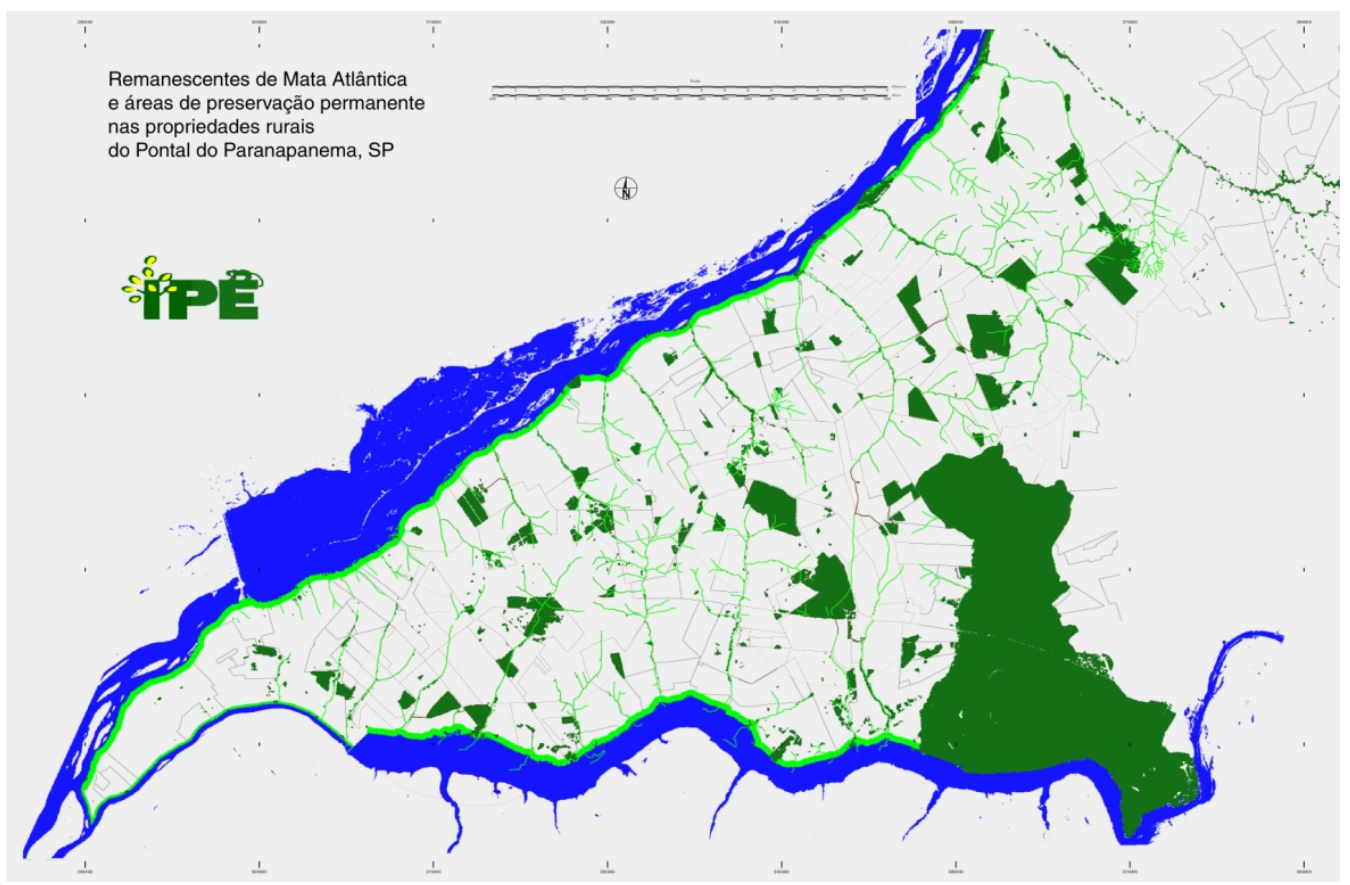

Figura 2 - Remanescentes florestais no Pontal do Paranapanema circundados por assentamentos da reforma agrária. O maior remanescente (canto inferior direito) é o Parque Estadual Morro do Diabo (36.500 ha)

Um dos aspectos relevantes da Biologia da Conservação e da Medicina Veterinária nos ungulados taiassuídeos é que todos os membros desta família estão desaparecendo em certas regiões devido à caça predatória e à destruição do seu hábitat. A onça parda (Puma concolor) e a onça pintada (Panthera onca) são os principais predadores dos porcos-do-mato. Porém, o homem é o único predador que pode ter um efeito significante sobre estas espécies em sua área de distribuição (TERBORGH et al., 2001).

Alguns autores citam que os taiassuídeos são suscetíveis a doenças comuns aos suínos domésticos e selvagens (MARGARIDO; MANGINI, 2001). A possibilidade da ocorrência de zoonoses envolvendo os taiassuídeos deve ser considerada tanto nas criações em cativeiro como em populações selvagens. $\mathrm{Na}$ distribuição geográfica dos taiassuídeos, em áreas onde essas espécies são encontradas, sempre há a presença de animais domésticos.

A situação torna-se mais freqüente no sul e sudeste da América do Sul, como por exemplo, a região do Pontal do Paranapanema, com a intensa fragmentação de habitat e o maior adensamento humano na paisagem ocorridos nos últimos anos.

Entre os carnívoros presentes, no Parque Estadual Morro do Diabo e nos fragmentos florestais vizinhos, destacam-se: a onça pintada (Panthera onca), a onça 
parda ou suçuarana (Puma concolor) e a jaguatirica (Leopardus pardalis). "Estes três felinos estão listados no "livro vermelho" das espécies brasileiras ameaçadas de extinção (IBAMA, 2003) e, no Ranking dos felinos selvagens, a onça pintada está classificada como "quase ameaçado", ou seja, em um futuro próximo a espécie tende a se tornar ameaçada (IUCN, 2007).

Quando a biodiversidade é perdida e a composição das espécies é alterada, processos ecológicos são interrompidos e sérios problemas envolvendo saúde começam a surgir (TABOR, 2002). Sendo assim, o entendimento das interconexões entre as espécies e a complexidade dos problemas de saúde envolvendo aspectos ecológicos da paisagem é necessário para avaliação das conseqüências epidemiológicas da fragmentação florestal. 


\section{REVISÃO DE LITERATURA}

Nesta seção é feita uma revisão sobre as espécies silvestres envolvidas neste estudo e os agentes patogênicos abordados e sua ocorrência em animais selvagens, especialmente os felídeos e taiassuídeos.

\subsection{TAIASSUÍDEOS BRASILEIROS}

Os taiassuídeos são um grupo de mamíferos do Novo Mundo, e são relacionados superficialmente como similares aos porcos domésticos e porcos do Velho Mundo. São compreendidas três espécies pertencentes a este grupo, os catetos (Tayassu tajacu), queixadas (Tayassu peccari) e o chacoan peccary (Catagonus wagneri), este último presente no oeste do Paraguai, norte da Argentina e na parte leste da Bolívia (SOWLS, 1996).

A posição dos taiassuídeos em relação a outros animais pertencentes à Classe Mamalia e Ordem Artiodactyla é Subordem Suiformes, Família Tayassuidae. O queixada (Tayassu pecari) e o cateto (Tayassu tajacu) compreendem duas das espécies mais caçadas nas florestas tropicais, encabeçando a lista de animais abatidos para consumo das comunidades locais (BODMER et al., 1996; CULLEN et al., 2000, 2001; ALTRICHTER;BOAGLIO, 2004). Estas duas espécies simpátricas, entretanto, diferem consideravelmente em relação à sua morfologia, ecologia e estrutura social, o que poderia afetar sua suscetibilidade à caça. Os queixadas são menos freqüentes que os catetos, mesmo em áreas que não tenham sido submetidas à perturbação ambiental. Os catetos, por outro lado, parecem persistir mesmo em áreas sujeitas à caça (CULLEN et al., 2000).

Alguns autores relatam ocorrências de doenças e agentes etiológicos infecciosos em populações selvagens de taiassuídeos (Quadro 1). Contudo, tais informações, na sua maioria, são pontuais e esporádicas, não observando características sazonais, inter-relação entre diferentes espécies suscetíveis a mesma doença e conseqüências de alterações ambientais, como a fragmentação, 
sobre a saúde dos animais. A ausência de informações a esse respeito implica no desconhecimento da real influência das doenças no status da população observada.

\begin{tabular}{|c|c|c|c|c|}
\hline Doença & Espécie & Localização & Evidência & Referência \\
\hline Cinomose & Cateto & U.S. A: Arizona & at/me/as & $\begin{array}{c}\text { (APPEL et al., } \\
1991 \text { ) }\end{array}$ \\
\hline $\begin{array}{l}\text { Encefalite Equina } \\
\text { Venezuelana }\end{array}$ & Cateto & U.S. A: Texas & as & $\begin{array}{c}\text { (SMART et al., } \\
\text { 1975) }\end{array}$ \\
\hline $\begin{array}{l}\text { Encefalite Eqüina } \\
\text { cepa Western }\end{array}$ & Cateto & U.S. A: Texas & as & $\begin{array}{c}\text { (SMART et al., } \\
1975)\end{array}$ \\
\hline Calicivirose & Queixada & Bolívia & as & $\begin{array}{c}\text { (KARESH et al., } \\
\text { 1998) }\end{array}$ \\
\hline $\begin{array}{c}\text { Virose dos leões } \\
\text { marinhos de San } \\
\text { Miguel }\end{array}$ & Queixada & Bolívia & as & $\begin{array}{c}\text { (KARESH et al., } \\
1998)\end{array}$ \\
\hline \multirow{4}{*}{ Brucelose } & \multirow{2}{*}{ Queixada } & $\begin{array}{c}\text { Brasil: Paraná, } \\
\text { Mato Grosso do } \\
\text { Sul }\end{array}$ & as & $\begin{array}{l}\text { (MANGINI et } \\
\text { al.,1998; ITO et } \\
\text { al., 1998) }\end{array}$ \\
\hline & & $\begin{array}{l}\text { Brasil: São } \\
\text { Paulo }\end{array}$ & as & $\begin{array}{c}\text { (NAVA; } \\
\text { CULLEN, 2003) }\end{array}$ \\
\hline & \multirow[b]{2}{*}{ Cateto } & Venezuela & ia & $\begin{array}{c}\text { (LORD e LORD, } \\
1991)\end{array}$ \\
\hline & & $\begin{array}{c}\text { Brasil: } \\
\text { Amazônia, São } \\
\text { Paulo, Mato } \\
\text { Grosso do Sul }\end{array}$ & as & $\begin{array}{l}\text { (MAYOR et al, } \\
\text { 2006; NAVA et } \\
\text { al., 2004; ITO et } \\
\text { al., 1998) }\end{array}$ \\
\hline Streptococose & Queixada & Bolivia & as & $\begin{array}{c}\text { (KARESH et al., } \\
\text { 1998) }\end{array}$ \\
\hline
\end{tabular}




\begin{tabular}{|c|c|c|c|c|}
\hline Doença & Espécie & Localização & Evidência & Referência \\
\hline Peste bubonica & Cateto & USA: Texas & - & $\begin{array}{c}\text { (GRUVER; } \\
\text { GUTHRIE; } \\
\text { 1996) }\end{array}$ \\
\hline Toxoplasmose. & Cateto & Panama & as & $\begin{array}{c}\text { (FRENKEL; } \\
\text { SOUSA, 1983) }\end{array}$ \\
\hline Borreliose & Cateto & USA: Texas & - & $\begin{array}{c}\text { (GRUVER; } \\
\text { GUTHRIE; } \\
1996 \text { ) }\end{array}$ \\
\hline \multirow{2}{*}{ Raiva } & Queixada & Bolívia & as & $\begin{array}{c}\text { (KARESH et al., } \\
1998)\end{array}$ \\
\hline & Cateto & U.S. A: Arizona & as & $\begin{array}{c}\text { (CORN et al., } \\
1987)\end{array}$ \\
\hline \multirow{2}{*}{ Leptospirose } & Queixada & Bolívia & as & $\begin{array}{c}\text { (KARESH et al., } \\
1998)\end{array}$ \\
\hline & Cateto & $\begin{array}{c}\text { U.S. A: Arizona } \\
\text { Brasil: } \\
\text { Amazônia }\end{array}$ & as & $\begin{array}{c}\text { (CORN et al., } \\
\text { 1987; MAYOR } \\
\text { et al., 2006) }\end{array}$ \\
\hline
\end{tabular}

Quadro 1 - Algumas doenças encontradas em populações silvestres de queixadas ( $T$. pecari) e catetos ( $T$. tajacu) no sudoeste Norte Americano, América Central e do Sul. (at: Anticorpos teciduais; me: microscopia eletrônica; as: anticorpo sérico; id: imunofluorescência direta; ia: isolamento do agente)

Os queixadas formam os maiores bandos e a maior biomassa forrageadora de todos os ungulados neotropicais, deslocando-se em grupos que excedem a 200 indivíduos. Talvez, para satisfazer as altas necessidades metabólicas de tão grandes grupos, os queixadas parecem executar um dos mais notáveis movimentos de longa distância do que qualquer mamífero não voador nas florestas neotropicais (FRAGOSO, 1994). Isto pode tornar as populações destas espécies altamente vulneráveis à extinção local em áreas de florestas fragmentadas, uma tendência que tem sido largamente ilustrada pelo seu desaparecimento de pequenos fragmentos 
florestais na Floresta Atlântica do sudeste do Brasil e América Central (CULLEN et al., 2000).

$\mathrm{Na}$ Estação Ecológica de Maracá em Roraima, se documenta o desaparecimento de queixadas, e a maior hipótese desta queda de população é atribuída a ocorrência de alguma doença infecto contagiosa (FRAGOSO, 1997).

\subsection{ONÇAS PINTADAS, ONÇAS PARDAS E JAGUATIRICAS}

No Parque Estadual Morro do Diabo e nos fragmentos florestais vizinhos, entre os carnívoros presentes destacam-se: a onça pintada (Panthera onca), a onça parda ou suçuarana (Puma concolor) e a jaguatirica (Leopardus pardalis). Segundo - IBAMA (2003) estes três felinos encontram-se entre as espécies brasileiras ameçadas de extinção. Essas três espécies de felinos são importantes indicadores ecológicos e essenciais para a manutenção da integridade ecológica do ecossistema (GREENE, 1988). Segundo a "hipótese da diversidade de predadores" a presença no topo da cadeia alimentar, seguido do controle populacional via predação - em queixadas, catetos, veados, cotias, capivaras, lagartos etc. - exercido por esses grandes gatos, tem papel fundamental no controle natural da densidade dessas presas e, conseqüentemente, na integridade e diversidade biológica da floresta (TERBORGH, 1990).

\subsection{AGENTES PATOGÊNICOS E SUA OCORRÊNCIA EM FELÍDEOS SELVAGENS E TAIASSUÍDEOS}

Nesta sub-seção é realizada uma revisão sobre os agentes patogênicos pesquisados neste estudo, e em especial sua ocorrência nos taiassuídeos e felídeos selvagens. 
2.3.1 Vírus da imunodeficiência felina (FIV) e leucemia felina (FELV)

Algumas doenças típicas de felinos merecem atenção especial quando suas populações se encontram em ambientes de florestas fragmentadas. Lentiviroses relacionadas ao vírus da imunodeficiência felina de gatos domésticos têm sido descritas em várias espécies dentro de família Felidae (OLMSTED, 1992; CARPENTER et al., 1996; OSTROWSKY et al., 2003). Cerca de 18 membros, dentro das 37 espécies pertencentes à família Felidae, possuem um vírus relacionado ao FIV que tem sido identificado através da presença de anticorpos que reagem com antígenos de FIV no soro desses animais (CARPENTER et al., 1996).

Em um estudo em zoológicos da América do Norte, três felídeos neotropicais de cativeiro estavam em fase de viremia de FeLV, estes eram um gato maracajá (Leopardus wiedii) e dois gatos palheiros (Oncifelis colocolo) (KENNEDYSTOSKOPF, 1999).

O FeLV que é um Gammaretrovírus, e os demais lentivírus felinos, como o FIV (CARPENTER et al., 1996) pertencem à família Retroviridae; associam-se com uma variedade de síndromes desenvolvendo tumores malignos de longa latência, doenças de emagrecimento progressivo e desordens neurológicas e imunodeficiências em gatos domésticos em todo o mundo (WOORLEY, 2001).

O FIV e FeLV são vírus que têm o seu contágio determinado através do contato de um gato portador do vírus para um gato sadio (LURIA et al., 2004), e são as duas doenças infecciosas mais comuns em gatos. Ambas são viroses que causam imunossupressão em gatos domésticos. A maior rota de transmissão para FeLV é através da saliva dos gatos (FILONI et al., 2003; LURIA et al., 2004), devido ao hábito dos felinos de se lamberem uns aos outros, secreções nasais (FILONI et al., 2003), dividir vasilhas de alimento ou liteiras, mordidas e arranhões (LURIA et al., 2004).

O FIV causa imunodeficiência em gatos domésticos porque envolve a depleção da população de CD41 dos linfócitos T, levando a uma suscetibilidade à doenças infecciosas oportunistas e podendo culminar em morte (ENGLISH et al., 1994).

A principal rota de FIV é através de mordidas e arranhões entre os felinos. $\mathrm{O}$ diagnóstico realizado rotineiramente em gatos domésticos é ELISA e testes 
imunocromatográficos para detecção do antígeno solúvel p27 ou anticorpo para FIV, em sangue total, soro ou plasma de gatos (LURIA et al., 2004).

$\mathrm{Na}$ maioria dos estudos relacionados à FIV em felídeos selvagens, não foi relatada a patogenicidade aparente atribuída ao vírus (KENNEDY-STOSKOPF, 1999). Porém, em estudo de Carpenter et al. (1996), envolvendo seqüenciamento do vírus FIV em pumas, em um indivíduo amostrado, o FIV encontrado no puma era característico de gato doméstico, sugerindo uma recente transmissão do vírus entre espécies diferentes.

\subsubsection{Vírus da cinomose canina (CDV)}

A cinomose é uma doença altamente infecciosa, causada por um RNA vírus, da família Paramyxoviridae e do gênero Morbillivirus. Acomete todas as famílias da ordem Carnivora, sendo os canídeos bastante suscetíveis e importantes na epidemiologia da doença (WILLIANS, 2001).

Durante muito tempo acreditou-se que a cinomose (CDV) não causava doença em felinos, em decorrência de estudos nos quais gatos infectados apresentavam um discreto aumento da temperatura corporal, sem eliminação do vírus (APPEL et al., 1974). Apenas quando houve uma epizootia por CDV em diversas espécies de felídeos em zoológicos norte americanos que a importância deste patógeno foi reconhecida para a famíla Felidae (KENNEDY-STOSKOPF, 1999). Posteriormente, houve outra epizootia em população de leões de vida livre no Serengeti, África, que eliminou cerca de 30 \% da população em 1994 (ROELKEPARKER et al., 1996) e nos Estados Unidos atingiu a última colônia de furões-depatas negras (Mustela nigripes) na natureza causando morte de vários indivíduos (WILLIANS et al., 1988).

A epizootiologia da doença está relacionada a contato com canídeos infectados e nos Estados Unidos, também ao contato com guaxinins (Procyon lotor) infectados (RAMOS SILVA; ADANIA, 2007).

A cinomose em felinos infectados produz sintomas neurológicos, respiratórios e gastrointestinais. Entretanto, $60 \%$ dos casos reportados em felídeos somente os sintomas neurológicos estiveram presentes, incluindo convulsões, encefalomielites, 
fraqueza, incoordenação entre outros (FILONI, 2006). Em estudo realizado no Parque Estadual de Ivinhema, três onças pintadas e uma onça parda de vida livre foram reagentes para cinomose (NAVA et al., 2007). Em populações isoladas, o vírus da cinomose, quando é introduzido, costuma ocorrer de forma epidêmica, acometendo cães de todas as idades (LEIGHTON et al., 1988). Em zoológicos do Brasil, de 1989 a 1994 houve morte de filhotes de lobos-guarás em decorrência de um surto de cinomose (REGO et al.,1997), como também em cachorro vinagre (CUBAS, 1996). Após programa de vacinação com vírus vivo modificado, cultivado em células de aves, os casos de cinomose entre os filhotes de lobo guará decresceram (PESSUTI; SANTIAGO, 1994). Em um zoológico da Europa, o vírus da cinomose é indicado como a causa mortis em ursos polares filhotes (RAMSAY, 2003) e mediante sorologia, pandas em cativeiro foram reagentes ao vírus da cinomose (MAINKA et al.,1994). Catetos e queixadas também são suscetíveis a cinomose, apresentando sintomas neurológicos como letargia, ataxia e tremores (CORN et al., 1987). Estudos sorológicos com amostras de catetos de vida livre no sudeste dos Estados Unidos foram reagentes ao vírus (APPEL et al., 1991). E NOON et al. (2003) observou um surto de cinomose em catetos de vida livre no Arizona, e o vírus da cinomose foi isolado dos animais afetados. Em um período de quatro anos testando soro de catetos capturados nesta região, 58\% das amostras foram reagentes, sugerindo que a cinomose seja enzoótica naquela população.

A transmissão do vírus da cinomose ocorre principalmente através de contato com secreções orais, respiratórias ou oculares, em aerossóis contendo o agente, e também animais com infecção subclínica podem eliminar o agente (APPEL, 1987). Estima-se que $25 \%$ a $75 \%$ dos cães domésticos infectados pela cinomose desenvolvem infecção subclínica e eliminam o vírus sem desenvolver a doença (GREENE; APPEL, 1998).

\subsubsection{Leptospirose}

Leptospirose é uma zoonose globalmente distribuída causada pelo gênero Leptospira que afeta animais domésticos e muitos animais silvestres. A leptospirose pode produzir ou não sintomas clínicos (WEBSTER et al.,1995), que em humanos 
incluí infecção de multíplos órgãos e potencialmente morte. O patógeno é considerado uma doença infecciosa emergente, exemplificado por recentes surtos na Nicaraguá, Brasil, índia, sudeste da Ásia e Estados Unidos (LEVETT, 2001).

A transmissão de leptospirose ocorre via contato com água ou solo contaminados, e seu ciclo epidemiológico envolve a interação com o animal reservatório, um meio ambiente de transmissão favorável e humanos ou fauna susceptíveis. Os fatores de risco associados com a infecção dependem das características e organização espacial do ecossistema e condições de vida da população suscetível (VINETZ et al., 2005).

O alcance da transmissão e cenários expostos, reservatórios e manifestações clínicas são determinados geralmente por dois sorovares. Em áreas urbanas, por exemplo, ratos (Ratus ratus e Ratus novergicus) são os principais reservatórios para $L$. icterohemorrhagiae, enquanto cães e gado são reservatórios para $L$. canicola e $L$. hardjo em áreas rurais (BARCELLOS et al., 2001).

Mundialmente há um aumento dos casos de leptospirose que tem sido associado com esportes e atividades de lazer, confirmando a suspeita do ciclo selvático da doença (MORGAN et al., 2002). A identificação de áreas de risco e seus sorovares associados são necessários para um eventual controle e eficiente investigação epidemiológica. É sabido que os taiassuídeos são suscetíveis à leptospirose, sendo reagentes no exame sorológico (CORN et al.,1987; NAVA; CULLEN, 2003) tendo sintomatologia clínica e morte (FOWLER, 1993; KARESH et al., 1998). Woods et al. (1968) testou o soro de 20 catetos no Novo México e não achou nenhum animal reagente. Já Corn et al. (1987), no Arizona, identificou 23 catetos reagentes para leptospirose, dentre 213 amostrados.

No Pantanal sul mato grossense foram descritos queixadas reagentes para os sorotipos copenhageni, icterohaemorragiae IV, panama, patoc e autumnalis. Neste mesmo estudo, os catetos foram reagentes para o sorotipo patoc (ITO et al.,1998).

Em trabalho na Amazônia com catetos em cativeiro, foram encontrados animais reagentes para os sorotipos butembo e autumnallis (MAYOR, 2006). Mais recentemente na mesma região, os sorogrupos Australis, Hebdomadis, Autumnalis, Bataviae, Djasiman, Grippothyphosa, Balum, Canicola, Mini, Tarassovi e Icterohaemorragiae, este dois últimos com as maiores titulações encontradas, sendo respectivamente 6.400 e titulação 3.200 (MENDOZA, 2007). 
Em felídeos de cativeiro do criadouro de animais silvestres da Itaipu Binacional e Zoológico Municipal Bosque Guarani foram encontrados em onças pintadas os seguintes sorovares: castellonis e hardjo; em suçuaranas grippotyphosa e bratilslava; jaguatiricas: butembo, patoc e grippotyphosa; em gatos maracajá: andamana, patoc, butembo e autumnalis; em gatos do mato pequeno : patoc (GUERRA-NETO et al., 2003). Em felídeos da Fundação Parque Zoológico de São Paulo foram indicados os seguintes sorovares mais prováveis: pomona, icterohaemorragiae e hardjo (CORREA et al., 2004).

\subsubsection{Brucelose}

A brucelose é uma doença que consta da antiga lista B da OIE, ou seja, uma doença transmissível que pode ser considerada de importância sócioeconômica e de saúde pública e que pode ter impacto significativo no comércio de animais e subprodutos (OIE, 2004). Nos bovinos o principal sinal clínico é o aborto ou expulsão prematura dos fetos. Em geral o aborto ocorre na segunda metade da gestação, podendo haver retenção placentária seguida de metrite, podendo causar infertilidade permanente. Tanto machos como fêmeas são susceptíveis à doença, porém as fêmeas gestantes são mais sensíveis e permanecem cronicamente infectadas devido à permanência das brucelas nos linfonodos e no útero (PAULIN; FERREIRA NETO, 2003). A brucelose é usualmente assintomática em fêmeas não prenhes. Clinicamente pode apresentar um ou mais destes sintomas: aborto, retenção de placenta, orquite, epididimite. Também o animal pode apresentar higromas envolvendo as articulações da perna, esta é uma manifestação comum da brucelose em países tropicais, e pode ser o único sintoma óbvio de infecção; o fluído do higroma é sempre infectado com Brucella. O produto do aborto é o principal fator de contaminação ambiental por brucelas. A porta de entrada mais freqüente é o trato gastro-intestinal, pela ingestão de pasto, forragens e água contaminada (ACHA; SZIFRES, 1986).

A Brucella abortus tem como hospedeiro preferencial o bovino, mas outros animais podem se infectar com este patógeno, podendo transmiti-lo novamente para os bovinos (PAULIN; FERREIRA NETO, 2003). Os cães não são acometidos pela 
Brucella abortus, porém são importantes carreadores de restos de aborto, até mesmo entre propriedades (VASCONCELLOS et al., 1987). Os suínos são preferencialmente acometidos pela Brucella suis, porém podem ser acometidos pela Brucella abortus (VASCONCELLOS et al., 1987), sendo que nos suínos a infecção por Brucella abortus é transitória, mas pode constituir uma importante fonte de infecção para os bovinos. Os bovinos por sua vez raramente se infectam com Brucella suis sendo que essa possibilidade está ligada ao hábito de compartilhar pastagens e instalações com suínos (PAULIN; FERREIRA NETO, 2003).

A brucelose já foi reportada em camelos de uma corcova (Camelus dromedarius) e duas corcovas (C. bactrianus). A brucelose também foi reportada em búfalos domésticos (Bubalus bubalus), bisão europeu e americano (Bison bonasus, Bison bison). As manifestações da brucelose nesses animais são semelhantes às que ocorrem no gado (OIE, 2004). A presença de brucelose nos bisões do Parque de Yellowstone foi talvez uma das políticas públicas mais controversas relacionadas a doenças em animais silvestres. Todo ano, bisões são mortos pelo Departamento de Pecuária quando eles migram para fora do Parque. O medo que os bisões transmitam brucelose para o gado doméstico, sem considerar a evidência contrária questiona toda essa política de manejo (TABOR, 2002). Meagher e Meyer (1994) afirmam que a Brucella foi introduzida no Parque de Yellowstone devido ao gado mantido pelos empregados do Parque.

Woods et al. (1968) examinou o soro de 20 catetos do Novo México e todos foram negativos para brucelose. Entretanto (MAYOR et al., 2006) encontrou anticorpos para Brucella spp. em 4.9\% (2/41) em catetos de cativeiro na região amazônica, e Lord e Lord (1991) num estudo bacteriológico e sorológico na Venezuela tipificou 43 vezes Brucella suis biovar 1 em isolados de linfonodo e baço de 25 catetos machos e 18 fêmeas e Brucella spp. em 122 de 139 catetos estudados.

Em estudos na região do Mato Grosso do Sul foram amostrados três catetos e nenhum deles foi reagente para brucelose (ITO et al., 1998).

No Paraná em animais de cativeiro 2 animais foram reagentes para brucelose (MANGINI et al., 1998). Na Itália de 562 porcos selvagens (Sus scrofa) nenhum foi reagente para Brucella spp. (EBANI et al., 2003), nos Estados Unidos, 8 wapitis (Cervus elaphus) dentre 456 amostrados em diferentes parques nacionais foram reagentes para $B$. abortus (AGUIRRE et al., 1995). Em focas do Hawai (Monachus 
schauinslandi), dentre 144 animais amostrados, $11.6 \%$ foram reagentes para Brucella spp. (AGUIRRE et al., 2007), e em focas de porto (Phoca vitulina richardsi) em regiões da costa do Alaska, 46\% (46/100) foram reagentes para Brucella spp (ZAMKE et al., 2006). 


\section{OBJETIVOS}

Nesta seção são descritos o objetivo principal e os objetivos específicos deste estudo, bem como suas hipóteses.

\subsection{OBJETIVO PRINCIPAL}

O objetivo principal é o estudo das conseqüências epidemiológicas da fragmentação florestal nas populações de animais domésticos, felinos (onças e jaguatiricas) e ungulados (porcos do mato) presentes no Parque Estadual Morro do Diabo e fragmentos florestais próximos, com a intenção de determinar o padrão de ocorrência de doenças na população silvestre.

\subsection{OBJETIVOS ESPECÍFICOS}

Meta I: Estudar a associação entre fragmentação florestal e a presença de doenças nas populações de taiassuídeos e felinos;

Hipótese: A prevalência e intensidade de parasitismo por carrapatos hospedeiroespecíficos com ciclo de vida direta e o número de animais reagentes para doenças infecto contagiosas deveriam ser maiores em taiassuídeos, onças e jaguatiricas em áreas com maior grau de fragmentação de hábitat (fragmentos de floresta) do que em áreas contínuas como o Parque Estadual Morro do Diabo.

Meta II: Estudar as relações entre fragmentação florestal e risco de transmissão de doenças entre animais domésticos, taiassuídeos e felinos;

Hipótese: $O$ risco de transmissão de doenças entre animais domésticos, taiassuídeos e felinos está relacionado ao grau de fragmentação de habitat, 
adensamento humano, densidade de animais domésticos nos entornos, distribuição espacial dos fragmentos, e doenças em que os animais domésticos foram reagentes. 


\section{MATERIAL E MÉTODOS}

Nesta seção são descritas as áreas de estudo, implementação, bem como metodologia de coleta de amostras e métodos diagnósticos utilizados.

\section{1 ÁREAS ESPECÍFICAS DE ESTUDO}

Foram estudadas as populações de taiassuídeos e felídeos nas florestas fragmentadas da Região do Pontal do Paranapanema, extremo oeste do estado de São Paulo. Nesta região, o maior fragmento com floresta contígua é o Parque Estadual Morro do Diabo, que consiste em 36.500 ha de floresta semidecidual primária. Os demais fragmentos na região foram reduzidos a retalhos florestais que variam menos de 400 ha até aproximadamente 2000 ha. Apresentando formas variadas, esses fragmentos menores estão dispostos em maior ou menor grau de isolamento ao redor do Parque Estadual Morro do Diabo. Fazendas de gado, agricultura e assentamentos da reforma agrária são as atividades humanas predominantes que cercam os fragmentos e o Parque (SCHLOEGEL et al., 2005).

O Parque Estadual foi considerado área "controle" no estudo, assumindo-se que as populações de taiassuídeos e felinos presentes nele sejam mais estáveis. Adicionalmente, serão estudadas as populações de quatro fragmentos de floresta relativamente grandes (entre 1100 e $2000 \mathrm{ha}$ ) e tres menores (entre 400 e $600 \mathrm{ha}$ ).

Os fragmentos diferem no grau de isolamento entre si e entre a floresta contínua (Parque Estadual Morro do Diabo). Fragmentos abaixo de 400 ha não foram amostrados porque que essas áreas não possam manter populações viáveis de taiassuídeos (KEUROGHLIAN et al., 2004). Também se assume que fragmentos entre 400 a 600 ha não têm populações viáveis de queixadas. A seguir, descreve-se os fragmentos de floresta de captura dos animais.

1. Parque Estadual Morro do Diabo: considerado como área contínua ( 36.500 ha)

2. Fragmentos pequenos

Fragmento Ribeirão Bonito (500 ha) 
Fragmento Santa Zélia (400 ha)

Fazenda Santa Mônica/São Paulo (584 ha).

3. Fragmentos grandes

Fazenda Tucano/Rosanella/Nova Canaã (1.990 ha);

Fazenda Ponte Branca (1.195ha);

Fazenda Água Sumida/Estrela Alcídia (1.135 ha).

Fazenda Santa Maria B/Cachoeirinha (1732 ha).

Em cada fragmento alvo deste estudo foram realizados 3 (três) eventos ou campanhas de capturas mensais. Uma campanha representa 7 dias consecutivos de esforço de captura.

A implementação do estudo teve dois componentes principais:

a. Captura e imobilização de taiassuídeos e felinos silvestres avaliação dos parâmetros de condição corporal e sanidade animal, coleta de material para realização de testes sorológicos e para tentativa de isolamento dos agentes e avaliação da carga de ectoparasitos e endoparasitos.

b. Exames sorológicos e tentativa de isolamento dos agentes em animais domésticos ao redor dos fragmentos, com o objetivo de determinar a distribuição dos animais reagentes as doenças selecionadas.

\subsection{COLETA DE AMOSTRAS PARA TAÍASSUÍDEOS}

Durante um estudo piloto deste projeto, 12 queixadas e 8 catetos foram capturados, estabelecendo a viabilidade da metodologia aqui detalhada. O tamanho da amostra necessária para estimar a prevalência das diversas doenças dos taiassuídeos no Parque Estadual Morro do Diabo (floresta contínua) foi 130 taiassuídeos, e nos fragmentos o tamanho da amostra necessária foi de 120 animais.

Este valor permite identificar diferenças significativas entre os mesmos com $95 \%$ de confiança e poder de $75 \%$, considerando-se uma prevalência esperada de $5 \%$ nos animais de áreas íntegras e $15 \%$ nos animais de áreas fragmentadas (MINI TAB 14). 
Inicialmente a presença dos grupos de taiassuídeos é determinada através de sinais deixados por estes animais no ambiente como pegadas, cheiro e marcas no solo, devido ao comportamento de fuçar destes animais. Nos locais onde estes sinais evidenciavam-se mais recentes e intensos, foram instaladas cevas e currais de captura.

Confirmada a freqüência dos queixadas e catetos nas cevas de alimentação, foram construídos cercados de captura nas dimensões de 12.0 metros de comprimento por 6.30 metros de largura e 2.20 metros de altura, construídos com tábuas resistentes de madeira e justapostas. No interior dos cercados foram instalados cochos cobertos, onde foi mantida alimentação constante, constituída de milho seco. A porta do cercado do tipo guilhotina, sustentada por um pedaço de madeira (gatilho) que, por sua vez, estava conectado a um cordão para o desarme, ou isca, posicionada no solo atrás do cocho de alimentação. O posicionamento do cocho de alimentação permite a entrada de um grupo grande de animais no cercado. Uma vez capturado o grupo é manipulado por meio de contenção física utilizando-se uma caixa de contenção acoplada à porta de entrada do curral, onde cabem dois animais adultos separados por uma pequena guilhotina localizada na parte central da caixa de contenção.

Cada taiassuídeo capturado recebeu um brinco numerado, e foi anotado o sexo e estimada a idade em classes de adulto, subadulto e jovem através de parâmetros dentários e pelagem (FRAGOSO, 1994). Quando em plano anestésico os animais tiveram sua condição corporal avaliada, efetuada a coleta de sangue, fezes da ampola retal, swab vaginal ou prepucial.

Os animais foram manipulados após contenção química, com exceção dos filhotes que eram manipulados através de contenção física.

Com relação aos anestésicos, foi utilizada a associação tiletamina-zolazepam (Zoletil $^{\circledR}$, Virbac) nas seguintes dosagens recomendadas por $\mathrm{kg}$ de peso: cateto de 3,0 a $3,5 \mathrm{mg}$; e queixada $5 \mathrm{mg}$. 


\subsection{COLETA DE AMOSTRA DE FELÍDEOS}

Os felídeos silvestres foram capturados com armadilhas de ferro e, também, com cães treinados. Foram imobilizados quimicamente com o uso de dardos com uma combinação de tiletamina $\mathrm{HCl}$ e zolazepam $\mathrm{HCl}\left(\right.$ Telazol $^{\circledR}$, Fort Dodge, lowa, USA) na dosagem de $5.5 \mathrm{mg} / \mathrm{kg}$ para jaguatiricas; 4-6mg/Kg para onça pintada e 4.4 $\mathrm{mg} / \mathrm{kg}$ em onça parda.

Em todos os felinos capturados foram coletados carrapatos, determinada massa corporal através de balança de precisão e avaliação de estado reprodutivo nas fêmeas por meio de palpação abdominal.

\subsection{COLETA DE AMOSTRAS DOS ANIMAIS DOMÉSTICOS}

Com a permissão dos proprietários do entorno do PEMD e fragmentos foram coletados sangue e material biológico dos animais domésticos dessas propriedades, para sorologia e tentativa de isolamento para agentes infecciosos das doenças selecionadas. A amostragem dos animais domésticos em cada propriedade foi realizada de modo aleatório.

Foram amostrados gado bovino, eqüino, ovinos, suínos, felinos e cães. Para estimar a soroprevalência de doenças infecto-contagiosas nas populações de animais domésticos no entorno do PEMD (Parque Estadual Morro do Diabo) e fragmentos foi calculada uma amostra mínima de 374 bovinos para cada grupo (áreas fragmentadas e não fragmentadas). Este valor foi calculado considerando-se uma prevalência de $50 \%$, levando-se em conta o levantamento prévio da quantidade de animais domésticos do entorno do PEMD de aproximadamente 14.000 animais, com precisão desejada de 5\% e confiança de 95\%. Em todas as outras espécies de animais domésticas houve tentativa de coleta da totalidade dos animais de cada propriedade.

A utilização de uma estimativa de soroprevalência de $50 \%$ maximiza o tamanho da amostra garantindo a precisão mínima de 5 \% (Epi Info software). 


\subsection{METODOLOGIA DE PROVAS SOROLÓGICAS E ISOLAMENTO DE AGENTES INFECCIOSOS}

O material biológico utilizado para sorodiagnóstico de leptospirose, brucelose, cinomose, imunodeficiência felina e leucemia felina foi soro dos animais silvestres e domésticos amostrados e os métodos diagnósticos utilizados estão demonstrados no quadro abaixo (Quadro 2).

\begin{tabular}{|l|l|l|}
\hline \multicolumn{1}{|c|}{ Doenças } & \multicolumn{1}{|c|}{ Teste Utilizado } & \multicolumn{1}{c|}{ Animais Avaliados } \\
\hline Brucelose & $\begin{array}{l}\text { Antígeno Acidificado } \\
\text { Tamponado, Soro } \\
\text { Aglutinação Rápida (SAR) e } \\
\text { Soro Aglutinação Lenta } \\
\text { em Tubo (SAT), utilizando } \\
\text { Brucella abortus }\end{array}$ & $\begin{array}{l}\text { Bovinos,suínos, cães } \\
\text { e taiassuídeos }\end{array}$ \\
\hline $\begin{array}{l}\text { Leptospirose } \\
\text { Microscópica }\end{array}$ & $\begin{array}{l}\text { Bovinos, suínos, cães, } \\
\text { taiassuídeos e felídeos }\end{array}$ \\
\hline Felina (FELC) & ELISA direto & Felideos \\
\hline Cinomose & Soroneutralização Lenta & $\begin{array}{l}\text { Cães, felideos } \\
\text { silvestres e } \\
\text { Taiassuídeos }\end{array}$ \\
\hline $\begin{array}{l}\text { Imunodeficiência } \\
\text { Felina (FIV) }\end{array}$ & ELISA indireto & Felídeos \\
\hline
\end{tabular}

Quadro 2 - Métodos diagnósticos empregados neste estudo

Dentre os métodos indiretos, a Soroaglutinação Microscópica (SAM) é o teste mais utilizado no sorodiagnóstico humano e animal da leptospirose, sendo inclusive o teste referência para outros testes sorológicos em fase de validação. Possui como vantagem a sensibilidade, quando comparado a outros testes, permitindo o diagnóstico em estágios precoces da infecção. É um teste específico para o sorovar infectante ou antigenicamente próximo, mas não permite a discriminação do tipo de 
imunoglobulina implicada na reação de aglutinação. As IgMs produzidas nas fases iniciais de infecção reagem amplamente com vários sorovares de leptospiras quando comparadas as IgGs produzidas posteriormente (CUMBERLAND et al., 1999). A técnica da soroaglutinação microscópica detalhada está descrita no (Anexo A). No quadro abaixo (Quadro 3), as variantes sorológicas de leptospiras empregadas como antígenos para a realização da soroaglutinação microscópica:

SOROGRUPO

Australis

Australis

Autumnalis

Autumnalis

Ballum

Batavia

Canicola

Celedoni

Cynopteri

Grippothyphosa

Hebdomadis

Icterohaemorrhagiae

Icterohaemorrhagiae

Javanica

Panama

Pomona

Pomona

Pyrogenes

Sejroe

Serjoe

Sejroe

Shermani

Tarassovi

Andamana

Seramanga

Djasiman

VARIANTE SOROLÓGICA (SOROTIPO)

Mini

Australis

Bratislava

Autumnalis

Butembo

Castellonis

Batavie

Canicola

Whitcombi

Cynopteri

Grippotyphosa

Hebdomadis

Copenhageni

Icterohaemorrhagiae IV

Javanica

Panama

Pomona

Fronn

Pyrogenes

Hardjo (hardjoprajitno)

Wolffi

Hardjo (hardjobovis)

Shermani

Tarassovi

Andamana

Patoc

Sentot

Quadro 3 - Relação das variantes sorológicas de leptospiras empregadas como antígenos para a realização da soroaglutinação microscópica.

Para o diagnóstico de cinomose foi utilizado o método de soroneutralização lenta. As amostras foram enviadas ao laboratório Biovet em Vargem Grande Paulista, São Paulo. A descrição da técnica de soroneutralização lenta encontra-se no (Anexo A). Para o diagnóstico de FIV e FeLV em gatos domésticos e felídeos selvagens foi utilizado testes sorológicos imunoenzimáticos comerciais, 
representados pelo Snap Combo FeLV Antigen/FIV Antibody Test Kit (IDEXX Laboratories, Inc., Westbrook, Maine 04092, USA), que em um único dispositivo combinam dois testes diferentes: um direto para antígeno viral p27 do FeLV e um indireto para anticorpos contra lentivírus felinos.

A tentativa de isolamento para leptospirose foi realizada utilizando-se a urina de animais silvestres capturados e animais domésticos amostrados.

A urina foi coletada através de sonda uretral específica para cada espécie animal. Para taiassuídeos, onças e jaguatiricas a coleta foi realizada com a utilização de sonda uretral para caninos. A técnica de isolamento para leptospirose está descrita no (Anexo B).

Para brucelose, a colheita de material para tentativa de isolamento foi feita através de swab vaginal ou prepucial dos animais domésticos e silvestres. $O$ material coletado foi conservado em meio de transporte de Stuart até a chegada ao laboratório. A técnica de isolamento para brucelose está descrita no (Anexo B).

\subsection{AVALIAÇÃO DO PARASITISMO (CARRAPATOS E ENDOPARASITAS)}

Os ectoparasitos coletados nos animais silvestres foram guardados vivos e trazidos para o laboratório de Parasitologia do Departamento de Medicina Veterinária Preventiva e Saúde Animal da Universidade de São Paulo para identificação.

Os estádios imaturos foram alimentados em coelhos para a obtenção dos estádios adultos e, em seguida, identificados através de chaves taxonômicas (BARROS-BATTESTI et al., 2006).

Os endoparasitas foram identificados em amostras de fezes coletadas diretamente do reto dos animais silvestres, e colocadas em tubo com bicromato de potássio. Os métodos utilizados para detecção dos endoparasitas foi CentrífugoFlutuação em Sacarose, Centrífugo-Sedimentação em Água-Éter e CentrífugoFlutuação em Sulfato de Zinco (Laboratório de Parasitologia VPS FMVZ USP).

Para avaliar a diversidade de ectoparasitas e endoparasitas encontrados em taiassuídeos capturados em cada fragmento de floresta, foram utilizados os seguintes índices de diversidade: índice de diversidade de Shannon, eveness, 
riqueza e similaridade. Hill's (1973) sugere que a noção de diversidade é um pouco maior do que a noção do número efetivo de espécies em uma amostra. Desta forma, a utilização de índices de diversidade ou heterogeneidade mede as espécies em comum em cada amostra e que vão produzir a mesma heterogeneidade (PEET, 1974). O índice de Shannon mede a abundância proporcional de uma amostra, e o índice de riqueza a abundância, desta forma, o índice de diversidade de Shannon engloba o índice de riqueza e o índice de igualdade ou "eveness" (STIRLING; WILSEY, 2001). O índice de igualdade mede a abundância relativa de espécies em uma comunidade, outro fator que afeta diversidade (WHITTAKER, 1965; HURLBERT, 1971), e que é medido por uma escala de 0 a 1 . O resultado 0 do índice de igualdade significa um baixo índice de igualdade, ou uma dominância de alguma espécie naquela amostra. Entretanto, um índice de igualdade de valor 1 indica uma igual abundância de todas espécies naquela amostra, ou um índice de igualdade máximo (MAGURRAN, 1988).

O índice de similaridade ou índice de Jaccard é baseado na relação entre o número de espécies comuns às duas áreas e o número de espécies em cada área e avalia a similaridade de cada área (DRUMOND, 1992). 


\section{RESULTADOS}

Nesta seção são descritos os resultados da amostragem de animais domésticos e silvestres; distribuição dos animais domésticos no entorno dos fragmentos de floresta e características de manejo de cada área; diagnósticos laboratoriais nas espécies estudadas.

\subsection{CARACTERÍSTICAS ECOLÓGICAS DOS TAIASSUÍDEOS}

Neste estudo foram amostrados 39 catetos (Tayassu tajacu) e 61 queixadas (Tayassu peccari) totalizando 100 animais capturados. No fragmento Santa Zélia (fragmento pequeno) foram capturados apenas dois indivíduos e não foram encontrados rastros que indicassem a presença de um grupo estruturado de catetos neste fragmento, estimando-se dois indivíduos ou três no fragmento. Nos fragmentos Santa Mônica (fragmento pequeno), Água Sumida e Santa Maria (fragmentos grandes) não foi possível capturar catetos.

No PEMD foram capturados 9 catetos, no grupo fragmentos pequenos próximos ao PEMD, que engloba os fragmentos Ribeirão Bonito e Santa Zélia, foram capturados 10 catetos. No grupo fragmentos grandes, que inclui os fragmentos de floresta Tucano e Ponte Branca, foram capturados 20 catetos. Abaixo a figura 3 demonstrando o número de catetos capturados nos diferentes fragmentos florestais. 


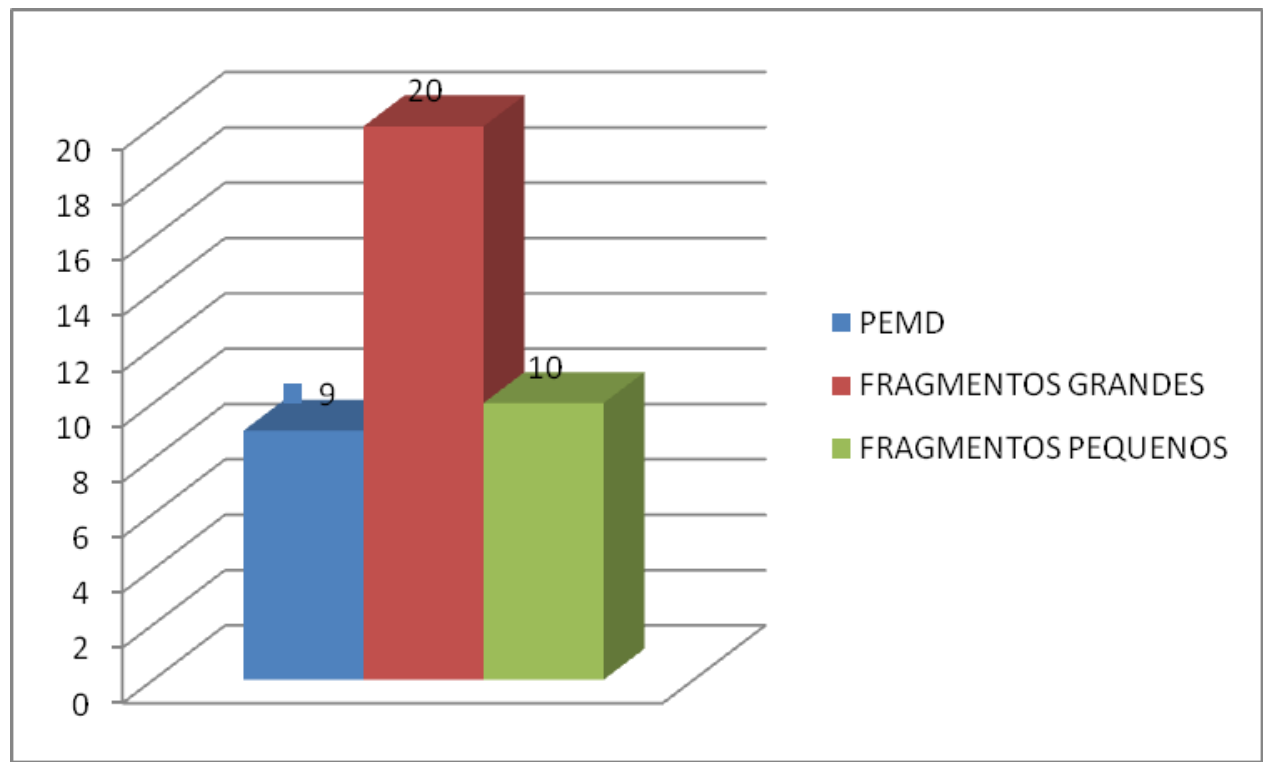

Figura 3 - Catetos capturados nos fragmentos agrupados por tamanho

Os queixadas amostrados foram provenientes do PEMD, fragmento florestal Santa Mônica e fragmento florestal Ponte Branca, este último parte da Estação Ecológica Mico Leão Preto. Foram amostrados 28 queixadas no PEMD, 15 animais no fragmento Ponte Branca (grupo fragmento grande), e 18 animais no fragmento Santa Mônica (grupo fragmento pequeno) como mostra a figura 4.

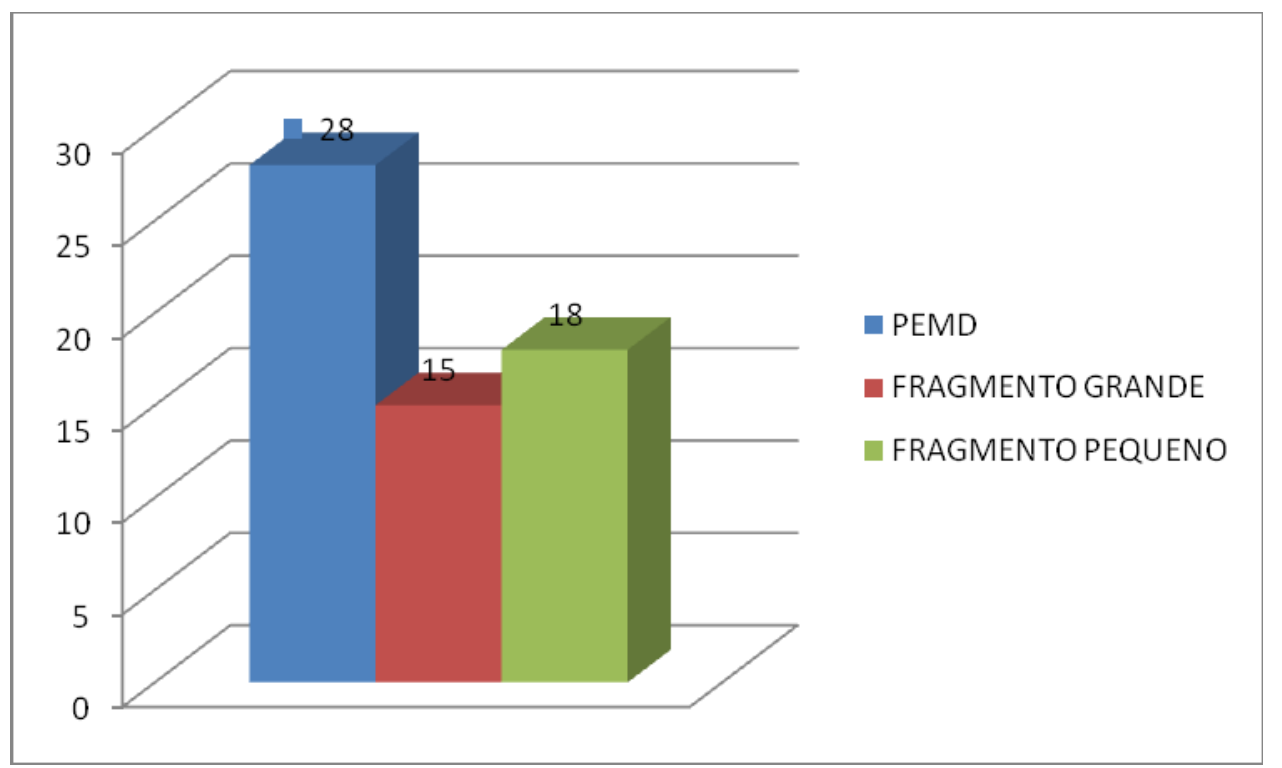

Figura 4 - Queixadas capturados nos fragmentos florestais do Pontal do Paranapanema 
Os fragmentos Água Sumida e Santa Maria, pertencentes ao grupo fragmentos grandes não foram capturados taiassuídeos nesses dois fragmentos, apesar da intensa campanha de captura.

Dentre os 39 catetos amostrados neste estudo, 23 eram fêmeas e 16 machos. Em relação a faixa etária as fêmeas capturadas são (n:14) adulta, (n:7) filhote , (n:1) juvenil e 1 sub adulto. Os machos são: (n:7) adulto, (n:1) ,filhote (n: 4), juvenil ( $n: 1)$ e sub adulto ( $n: 4)$.

Os queixadas e catetos são classificados em quatro categorias de idade baseadas na coloração, tamanho, status reprodutivo e análise dos molares.

Queixadas adultos são indivíduos grandes com queixo totalmente brancos e corpo marrom acinzentado. Os subadultos têm dois terços a três quartos do tamanho de um adulto, mantendo a coloração marrom avermelhada do juvenil. Os juvenis são animais com a coloração marrom avermelhada e têm a metade do tamanho de um adulto. Os filhotes representam um quarto do tamanho de um adulto e ainda mamam. Adicionalmente, pela análise dos molares podemos identificar se um indivíduo adulto é muito velho, observando os desgastes do dente e geralmente se os molares estão $2 \mathrm{~mm}$ acima da linha da gengiva. Nos adultos de meia idade, os molares estarão $2 \mathrm{~mm}$ a $3 \mathrm{~mm}$ acima da linha da gengiva. Nos adultos e adultos jovens, parte da coroa dos molares está 3 a $4 \mathrm{~mm}$ acima da linha da gengiva. Os juvenis adultos têm as mesmas características, mas retém a coloração de subadultos e mostram pequena parte do molar, 4 a $5 \mathrm{~mm}$ está acima da linha da gengiva. Na figura 5 encontra-se o mapeamento da idade estimada dos catetos capturados. 


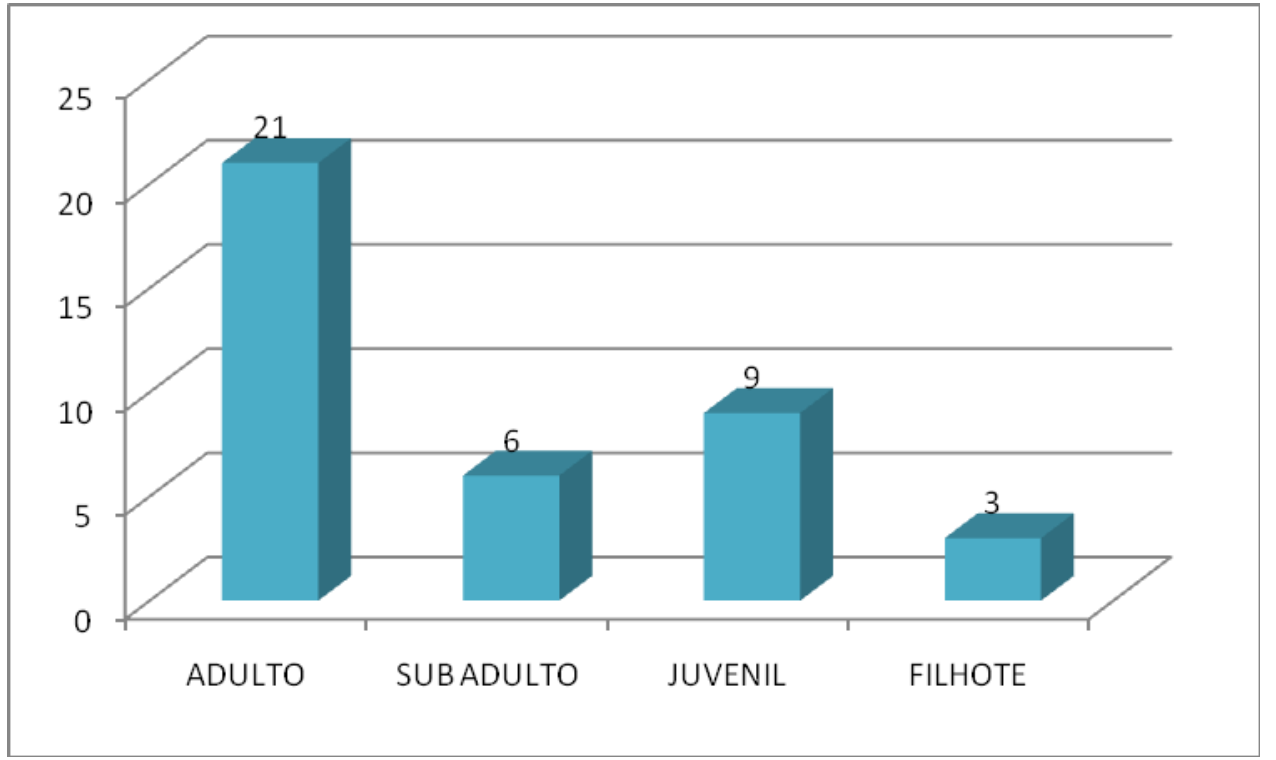

Figura 5 - Faixa etária dos catetos capturados no Pontal do Paranapanema

Dos queixadas amostrados (n:61), foram capturadas (n:40) fêmeas e (n:21) machos. A faixa etária das fêmeas capturadas foi: adulta ( $n: 29)$, filhote ( $n: 6)$, sub adulto (n:6). A faixa etária dos machos: adulto (n:8), filhote ( $n: 6)$, juvenil (n:2) e sub adulto (n:5), como mostra a figura 6 seguinte:

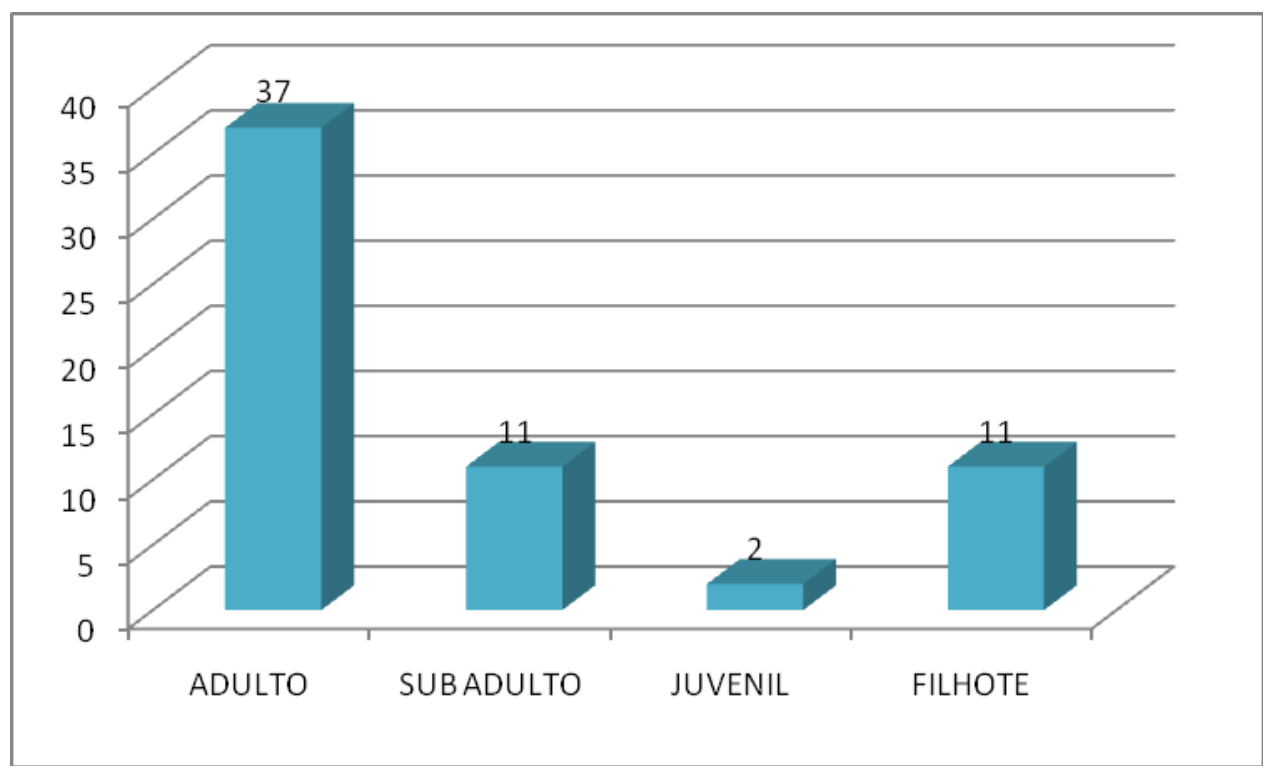

Figura 6 - Faixa etária dos queixadas capturados no Pontal do Paranapanema

A biomassa de fêmeas adultas e subadultas de catetos apresentou média aritmética de $18.8 \mathrm{~kg}$ e dos machos $15.25 \mathrm{~kg}$. Nos queixadas, a biomassa das 
fêmeas adultas e subadultas apresentou média de $31.11 \mathrm{~kg}$ e os machos $30.15 \mathrm{~kg}$. (Apêndice A).

\subsection{FELÍDEOS}

Os felídeos deste estudo foram capturados no PEMD e fazendas vizinhas ao PEMD. Foram no total oito onças pintadas, duas onças pardas e quatro jaguatiricas. Em trabalho envolvendo armadilhamento fotográfico para obtenção de quantidade de onças no PEMD, foi constatado que o número mínimo da população no PEMD é de 6 indivíduos, ou 2,22 indívíduos por $\mathrm{km}^{2}$ (CULLEN et al., 2005). Esses dados demonstram que a amostragem deste estudo é bastante alta para caracterizar epidemiologicamente a população de onças pintadas do PEMD.

As duas onças pardas capturadas eram machos adultos aparentemente saudáveis. Dentre as onças pintadas dois eram machos, e um dos animais foi considerado velho devido aos caninos bastante amarelados e gastos. Este indivíduo foi capturado duas vezes, sendo que na primeira captura apresentava-se bastante magro e debilitado. Na recaptura estava aparentemente saudável e tinha recobrado peso. Este animal foi reagente para leptospirose na segunda amostragem de soro. $O$ outro macho adulto foi reagente para brucelose.

As seis onças capturadas eram fêmeas, sendo uma delas filhote, capturada junto com a mãe.

As jaguatiricas eram dois machos, um jovem e um velho e duas fêmeas estando uma delas em lactação. Uma onça pintada fêmea e a jaguatirica que estava em lactação, alguns meses depois que foram amostradas, foram mortas por atropelamento na estrada Arlindo Bétio, que corta o PEMD ao meio.

\subsection{CARRAPATOS}

Os carrapatos, encontrados em catetos e queixadas, são do gênero Amblyomma e as espécies $A$. naponense, cajennense, $A$. brasiliense, A.coelebs e 
Amblyomma sp. Apenas em catetos e queixadas amostrados em fragmentos grandes, foram amostrados carrapatos da espécie Amblyomma brasiliense. $\mathrm{O}$. naponense foi o único ectoparasita que ocorreu em todas as campanhas de captura nos diferentes fragmentos. Os carrapatos encontrados nas onças pintadas foram ninfas de Amblyomma sp e fêmeas de Boophilus microplus.

Os índices utilizados neste estudo são os índices de riqueza (R1) e diversidade Shannon ( $\left.\mathrm{H}^{\prime}\right)$ mostrados no quadro 4 abaixo. O (NO) se refere ao número de espécies de carrapatos encontrados em cada espécie amostrada e em um determinado grupo de fragmento, e o (E) se refere ao eveness, ou índice de igualdade, que representa o equilíbrio entre o número de indivíduos encontrados entre as espécies.

\begin{tabular}{ccccc}
\hline Grupo & N0 & R1 & H & E \\
\hline PEMD & 4 & 0,70 & 1,01 & 0,73 \\
Grande & 5 & 0,82 & 1.46 & 0,90 \\
Pequeno & 2 & 0,20 & 0,11 & 0,17 \\
\hline
\end{tabular}

Quadro 4 - Índices de riqueza de carrapatos coletados em queixadas em três diferentes fragmentos florestais

O grupo fragmentos grandes mostrou maior riqueza em carrapatos coletados de queixadas como mostra o quadro 5 abaixo.

\begin{tabular}{ccccc}
\hline Grupo & N0 & R1 & H & E \\
\hline PEMD & 3 & 1,24 & 0,64 & 0,92 \\
Grande & 5 & 0,87 & 1,21 & 0,75 \\
Pequeno & 3 & 0,32 & 0,45 & 0,65 \\
\hline
\end{tabular}

Quadros 5 - Índices de riqueza de carrapatos coletados em catetos em três diferentes fragmentos florestais

Nos quadros 6 e 7 abaixo, os resultados do índice de similaridade de Jaccard entre os diversos fragmentos de estudo: 


\begin{tabular}{cccc}
\hline Cateto & $\begin{array}{c}\text { PEMD e } \\
\text { Fragmentos } \\
\text { pequenos }\end{array}$ & $\begin{array}{c}\text { PEMD e } \\
\text { Fragmentos } \\
\text { grandes }\end{array}$ & $\begin{array}{c}\text { Fragmentos } \\
\text { grandes e } \\
\text { fragmentos } \\
\text { pequenos }\end{array}$ \\
\hline $\begin{array}{c}\text { Indíce de } \\
\text { similaridade de } \\
\text { Jaccard }\end{array}$ & $66,6 \%$ & $40 \%$ & $40 \%$ \\
\hline
\end{tabular}

Quadro 6 - Medida de Similaridade de Jaccard entre os carrapatos coletados em catetos nas diferentes áreas

\begin{tabular}{cccc}
\hline Queixada & $\begin{array}{c}\text { PEMD e } \\
\text { Fragmentos } \\
\text { pequenos }\end{array}$ & $\begin{array}{c}\text { PEMD e } \\
\text { Fragmentos } \\
\text { grandes }\end{array}$ & $\begin{array}{c}\text { Fragmentos } \\
\text { grandes e } \\
\text { fragmentos } \\
\text { pequenos }\end{array}$ \\
\hline $\begin{array}{c}\text { Indíce de } \\
\text { similaridade de } \\
\text { Jaccard }\end{array}$ & $50 \%$ & $80 \%$ & $40 \%$ \\
\hline
\end{tabular}

Quadro 7 - Medida de Similaridade de Jaccard entre os carrapatos coletados em queixadas nas diferentes áreas

O grupo fragmentos grandes mostra maior riqueza em carrapatos coletados de catetos.

\subsection{ENDOPARASITAS}

Os endoparasitas encontrados nos taiassuídeos foram: Strongyloidea-like, Strongyloides-like, Ascarídeo-like, Giardia sp. e Ascarídeo Ascaris suum-like. Os coproparasitológicos dos felídeos selvagens foram todos negativos.

Dentre as fezes de catetos, analisadas nos diferentes fragmentos florestais, pelo menos um animal de cada localidade apresentou Ascarídeo like. No quadro 8 abaixo, os índices de diversidade para os endoparasitas coletados em fezes de catetos nos diferentes grupos de fragmentos florestais: 


\begin{tabular}{ccccc}
\hline Grupo & NO & R1 & $\mathbf{H}^{\prime}$ & E \\
\hline PEMD & 1 & 0 & 0 & - \\
FRAGMENTO & 5 & 1,44 & 1,39 & 0,86 \\
GRANDE & & & & \\
FRAGMENTO & 3 & 1,82 & 1,09 & 1 \\
PEQUENO & & & & \\
\hline
\end{tabular}

Quadro 8 - Índices de riqueza de endoparasitas coletados em catetos em três diferentes fragmentos florestais

No quadro 9 abaixo, os índices de diversidade para os endoparasitas coletados em fezes de queixadas nos diferentes grupos de fragmentos florestais:

\begin{tabular}{ccccc}
\hline Grupo & NO & R1 & $\mathbf{H}^{*}$ & E \\
\hline PEMD & 2 & 0 & 0,69 & 1 \\
FRAGMENTO & 2 & 1,67 & 0,67 & 0,97 \\
GRANDE & & & & \\
FRAGMENTO & 2 & 0 & 0,59 & 0,86 \\
PEQUENO & & & & \\
\hline
\end{tabular}

Quadro 9 - Índices de riqueza de endoparasitas coletados em queixadas em três diferentes fragmentos florestais

No quadro 10 abaixo, o índice de similaridade de Jaccard para os endoparasitas encontrados em fezes de catetos amostrados nos diferentes grupos de fragmentos florestais: 


\begin{tabular}{cccc}
\hline Cateto & $\begin{array}{c}\text { PEMD } \\
\text { e Fragmentos } \\
\text { pequenos }\end{array}$ & $\begin{array}{c}\text { PEMD } \\
\text { e Fragmentos } \\
\text { grandes }\end{array}$ & $\begin{array}{c}\text { Fragmentos } \\
\text { grandes } \\
\text { e fragmentos } \\
\text { pequenos }\end{array}$ \\
\hline $\begin{array}{c}\text { Indíce } \\
\text { similaridade de }\end{array}$ & 0 & $20 \%$ & $66,6 \%$ \\
Jaccard & & & \\
\hline
\end{tabular}

Quadro 10 - Medida de Similaridade de Jaccard entre os endoparasitas coletados em catetos nas diferentes áreas

No quadro 11 abaixo o índice de similaridade de Jaccard para os endoparasitas encontrados em fezes de queixadas amostrados nos diferentes grupos de fragmentos florestais:

\begin{tabular}{cccc}
\hline Queixada & $\begin{array}{c}\text { PEMD } \\
\text { e Fragmentos } \\
\text { pequenos }\end{array}$ & $\begin{array}{c}\text { PEMD } \\
\text { e Fragmentos } \\
\text { grandes }\end{array}$ & $\begin{array}{c}\text { Fragmentos } \\
\text { grandes e } \\
\text { fragmentos } \\
\text { pequenos }\end{array}$ \\
\hline $\begin{array}{c}\text { Indíce de } \\
\text { similaridade de } \\
\text { Jaccard }\end{array}$ & $33,33 \%$ & $33,33 \%$ & $66,6 \%$ \\
\hline
\end{tabular}

Quadro 11 - Medida de Similaridade de Jaccard entre os endoparasitas coletados em queixadas nas diferentes áreas

\subsection{ANIMAIS DOMÉSTICOS}

Com o objetivo de obter dados sobre a quantidade de animais e tipo de manejo de cada propriedade, esquema de vacinação e histórico informal da região sobre doenças infectocontagiosas nos animais domésticos, foram realizadas entrevistas com moradores das 214 propriedades vizinhas às florestas em estudo. A lista das propriedades amostradas encontra-se no (Apêndice E).

Foram amostrados 782 bovinos, 214 caninos, 193 eqüinos, 108 ovinos e 97 suínos como mostra a figura 7 abaixo. 


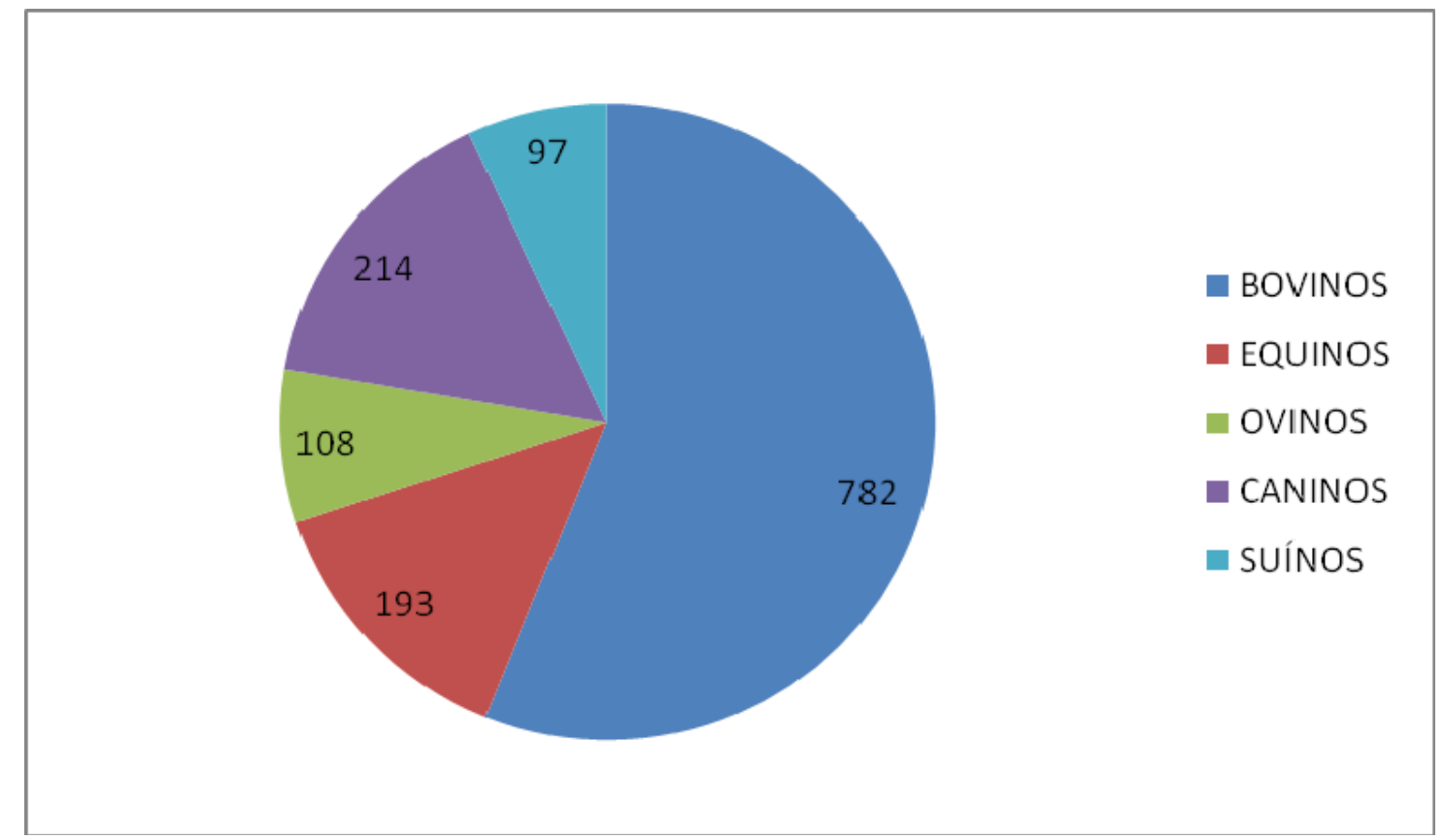

Figura 7 - Animais domésticos amostrados no Pontal do Paranapanema

\subsubsection{Animais domésticos do entorno do PEMD}

O entorno do PEMD é o mais heterogêneo em tipos de propriedades, comparado ao grupo fragmentos pequenos e grandes. No entorno da face norte do Parque há o predomínio de grandes fazendas com criação extensiva de gado de corte. Esse tipo de propriedade tem como característica ter um menor contato com a borda do Parque, sendo a sede da fazenda muito distante dos limites do Parque, na maioria das vezes maior que $5 \mathrm{~km}$ de distância. Essa distância limita o tráfego de animais domésticos como cães e gatos na borda do parque, diferentemente da face leste e oeste do Parque, onde as casas dos sitiantes e assentados estão muito próximas da borda da mata. Ainda na face norte, outro fator limitante à proximidade de gado e animais domésticos é uma estrada de terra, que liga duas estradas paralelas (estrada da Alcídia e estrada do Planalto), e que fica entre a divisa das fazendas e toda a borda norte do Parque.

$\mathrm{Na}$ face oeste, os animais domésticos e animais silvestres, por muito tempo, dividiram o mesmo recurso de água, o rio Ribeirão Bonito, que limita o Parque e o assentamento Ribeirão Bonito. Em 2007, a Polícia Ambiental local, juntamente com 
o Ministério Público Ambiental advertiram os proprietários para cercar a área e impedir a entrada de animais domésticos na borda do PEMD e no curso de água.

$\mathrm{Na}$ face noroeste, a fazenda Rosanella faz divisa com o PEMD, tendo as mesmas características das fazendas do norte do PEMD com criação extensiva de gado de corte.

$\mathrm{Na}$ face leste e na face oeste há uma maior proximidade dos animais domésticos do entorno com a borda do PEMD.

Na face sul do PEMD se encontra o rio Paranapanema que faz a divisa entre o Estado de São Paulo e Paraná.

O assentamento Ribeirão Bonito é constituído de propriedades pequenas, variando de 10 - 20 ha. Destaca-se o manejo rudimentar dos animais domésticos e adensamento de diversas espécies animais em um mesmo lote. Nesse assentamento, a maioria das propriedades não possui fossa séptica. A base da economia do assentamento Ribeirão Bonito é a venda do leite da propriedade para o laticínio local.

Nas figuras 8 abaixo a quantidade de bovinos no entorno do PEMD e animais amostrados, e na figura 9 a quantidade de suínos, ovinos, eqüinos e cães no entorno do PEMD e quantidade de animais domésticos amostrados no entorno do PEMD.

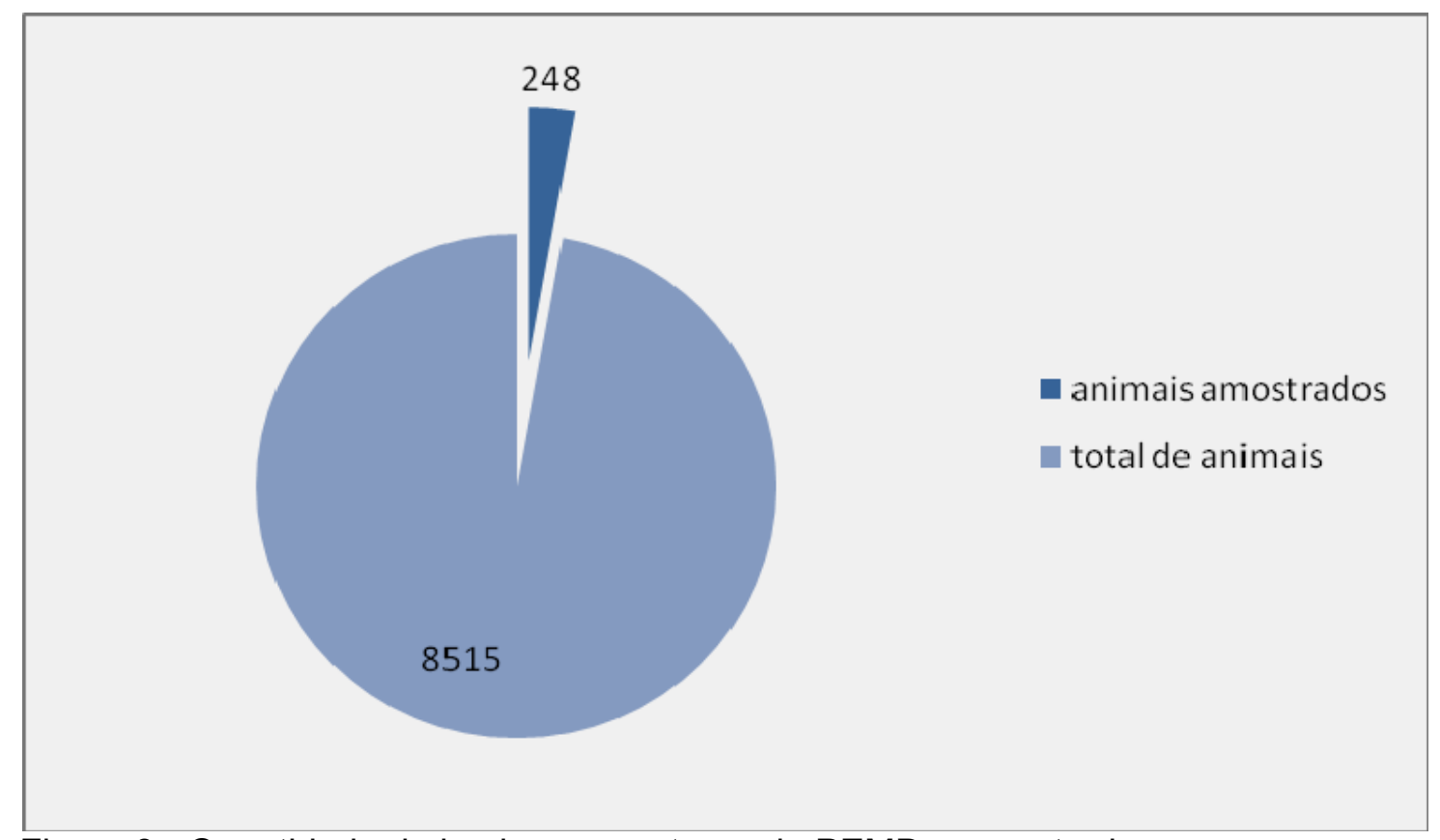

Figura 8 - Quantidade de bovinos no entorno do PEMD e amostrados 


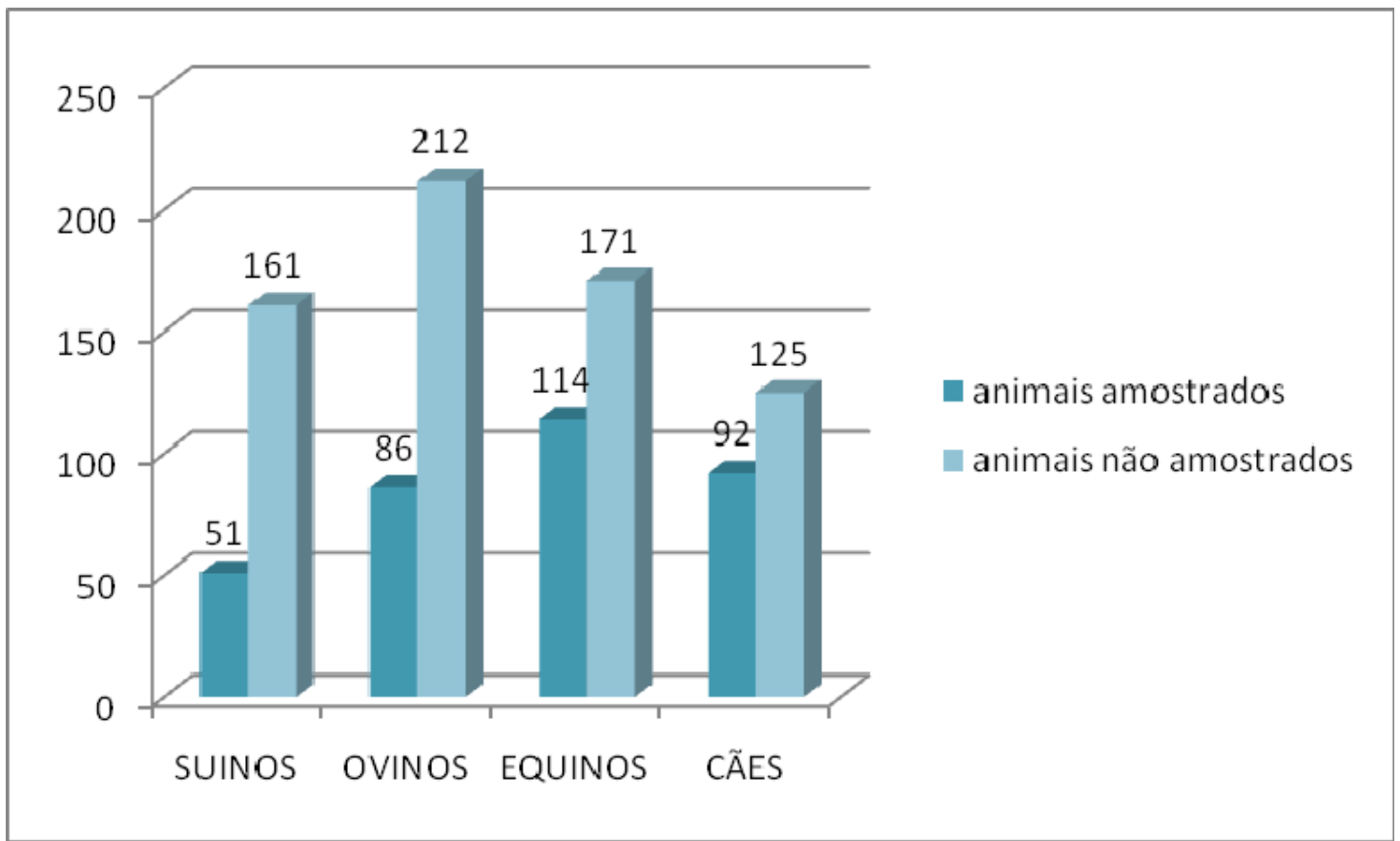

Figura 9 - Quantidade de suínos, ovinos, eqüinos e cães no entorno do PEMD quantidade de animais domésticos amostrados no entorno do PEMD

Nas fazendas, sítios e assentamentos do entorno do PEMD, as vacinas aplicadas ao gado são aftosa e brucelose. Os eqüinos são vacinados para "mal do rincho" - uma enfermidade que é associada à encefalomielite eqüina pelos proprietários rurais e veterinários locais. O esquema de vermifugação para todas as espécies das propriedades é com o uso de ivermectina injetável. Nos cães e gatos, o único esquema vacinal é anti-rábico, com a visita as propriedades dos profissionais do posto de saúde da cidade de Teodoro Sampaio.

5.5.2 Animais domésticos do entorno dos Fragmentos pequenos

Os fragmentos de floresta Ribeirão Bonito e Santa Zélia são circundados por assentamentos da reforma agrária, respectivamente os assentamentos: Ribeirão Bonito e Santa Zélia. Cada propriedade dentro destes assentamentos tem em média o tamanho de 10 a 20 hectares. O assentamento Santa Zélia segue as características do assentamento Ribeirão Bonito, pobre e com modos rudimentares de higiene e manejo de animais domésticos. Entretanto, o fragmento Santa Mônica é 
circundado pela fazenda Santa Mônica e fazenda São Paulo, duas fazendas extensivas de gado de corte. Nas visitas à floresta Santa Mônica era comumente observada a presença de gado dentro do fragmento. Os proprietários da fazenda São Paulo não permitiram a coleta de sangue dos animais domésticos da propriedade. Na figura 10 abaixo, a quantidade de animais no entorno de fragmentos pequenos (fragmento Santa Mônica, Santa Zélia e Ribeirão Bonito) e quantidade de animais domésticos amostrados.

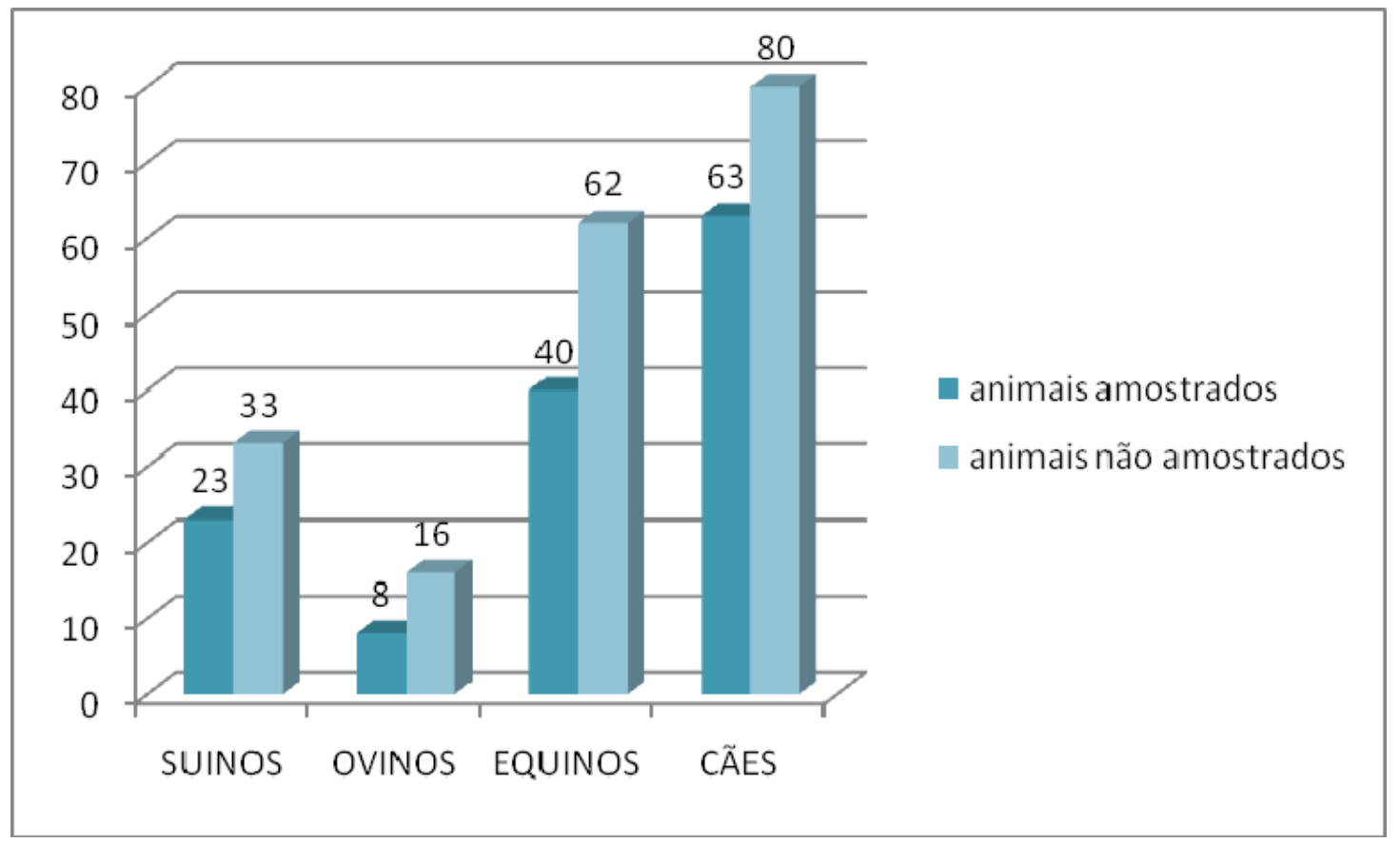

Figura 10 - Quantidade de animais no entorno de fragmentos pequenos (fragmento Santa Mônica, Santa Zélia e Ribeirão Bonito) e quantidade de animais domésticos amostrados

$\mathrm{Na}$ figura 11 abaixo, a quantidade de bovinos no entorno dos pequenos fragmentos de mata e número de animais amostrados. 


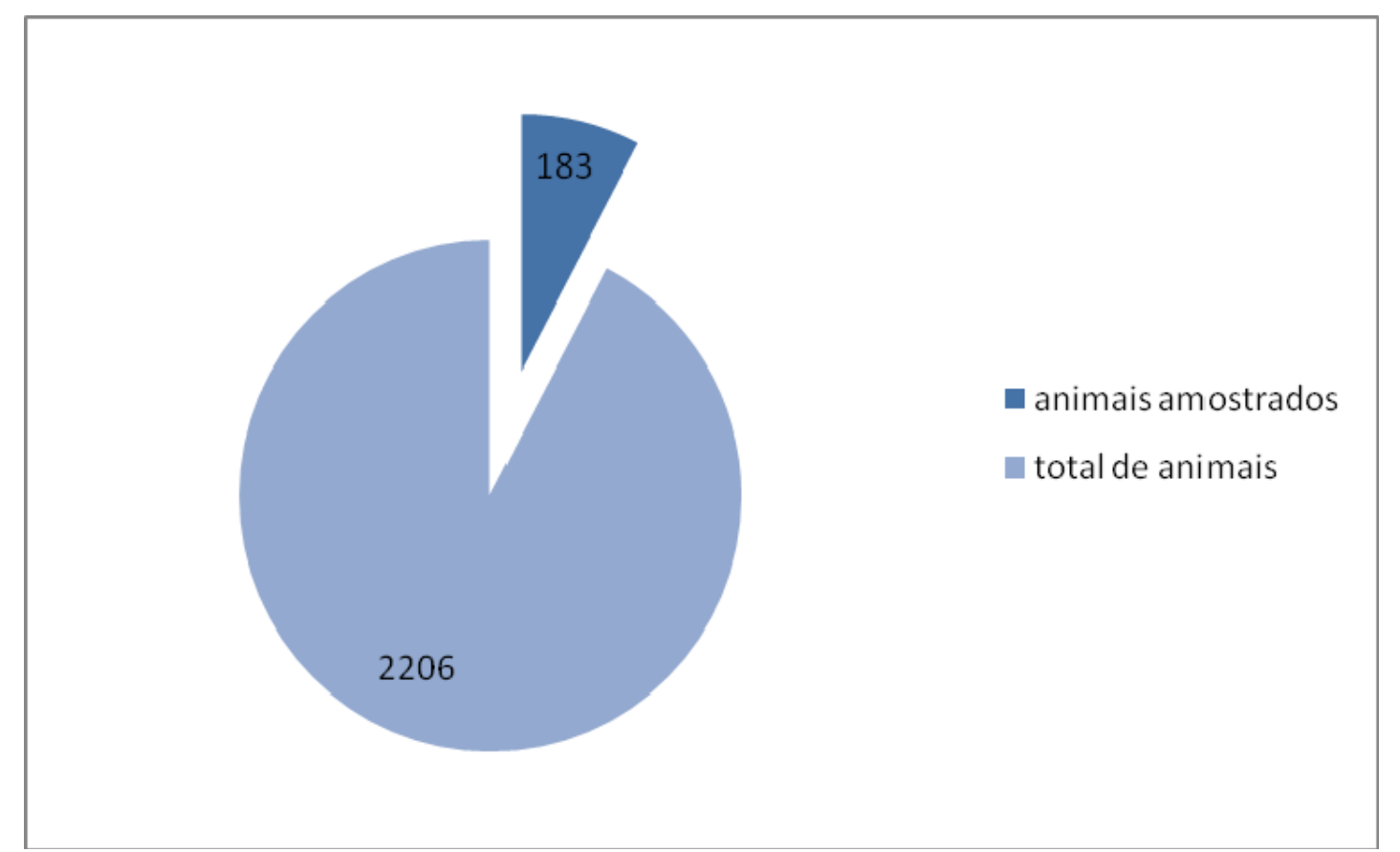

Figura 11 - Quantidade de bovinos no entorno dos pequenos fragmentos de mata e número de animais amostrados

O esquema vacinal das propriedades do entorno dos fragmentos pequenos segue o mesmo padrão das propriedades do entorno do PEMD. As vacinas utilizadas são contra a febre aftosa e brucelose no gado e anti-rábica nos cães e gatos perante visita dos profissionais dos postos de saúde locais.

5.5.3 Animais domésticos do entorno dos fragmentos grandes

O fragmento de floresta Ponte Branca, parte da Estação Ecológica MicoLeão-Preto é circundado pela fazenda Ponte Branca que tem criação extensiva de gado de corte. Os proprietários desta fazenda arrastavam todas as carcassas bovinas da propriedade para dentro do fragmento Ponte Branca. Neste "cemitério" foi observado rastros de onça pintada. Nesta fazenda não era permitida a criação de suínos, devido ao risco de brucelose para o gado.

O fragmento Tucano, também faz parte da Estação Ecológica Mico-LeãoPreto e é circundado pelo assentamento de reforma agrária Tucano. O fragmento Água Sumida é circundado pelo assentamento Água Sumida e o fragmento Santa 
Maria e pelo assentamento Santa Maria e fazendas Cachoeirinha e Maravilha, nessas duas não foi permitida a coleta de sangue dos animais domésticos. 0 esquema vacinal é o mesmo que ocorre no entorno dos demais grupos de fragmentos do estudo, vacinação para brucelose, febre aftosa e anti-rábica nos cães e gatos.

Os animais amostrados no entorno dos fragmentos grandes estão demonstrados nas figuras 12 e 13 abaixo.

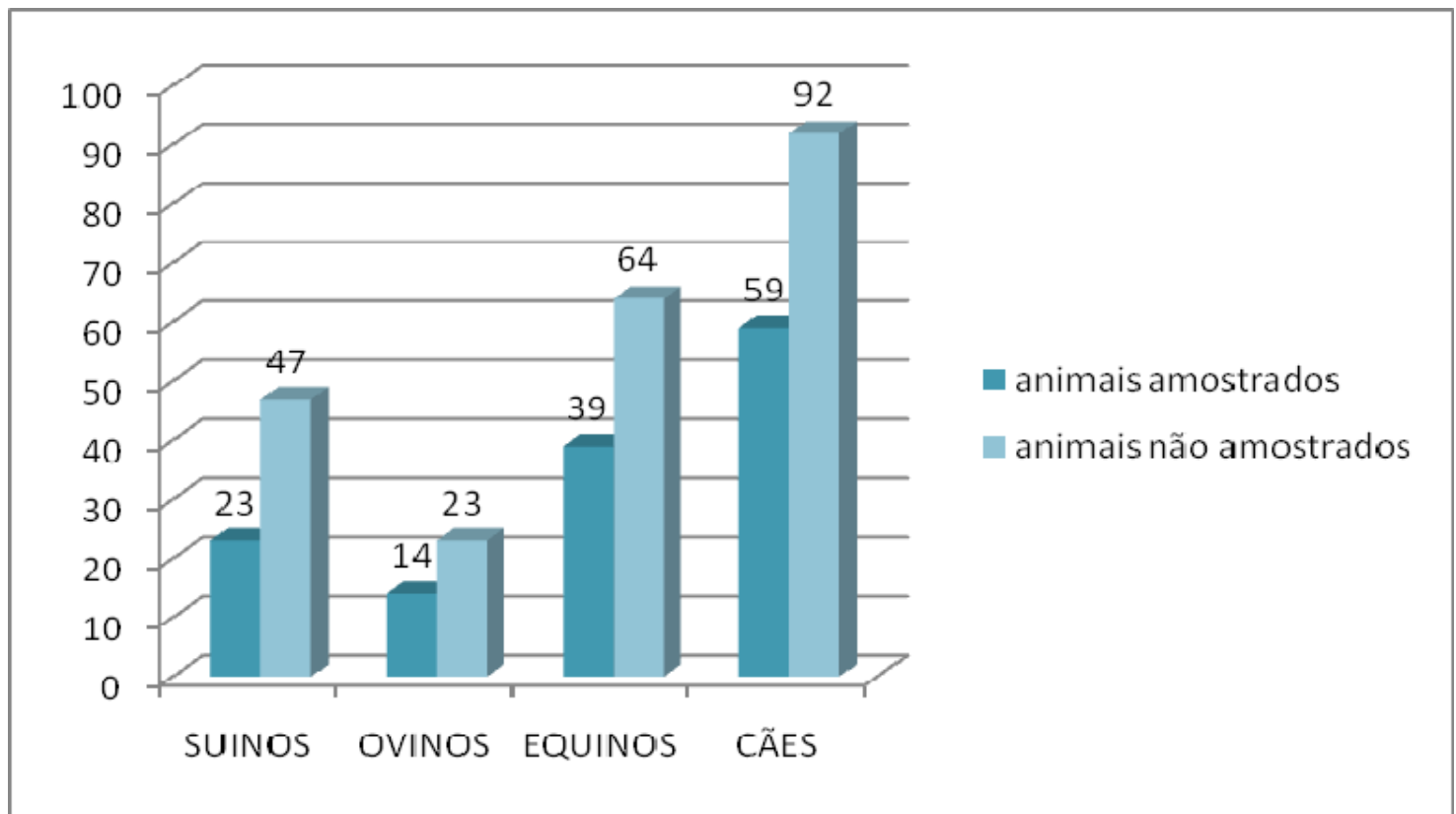

Figura 12 - Quantidade de suínos, ovinos, eqüinos e cães no entorno e animais domésticos amostrados no entorno dos remanescentes de mata Tucano, Ponte Branca, Água Sumida e Santa Maria (fragmentos grandes) 


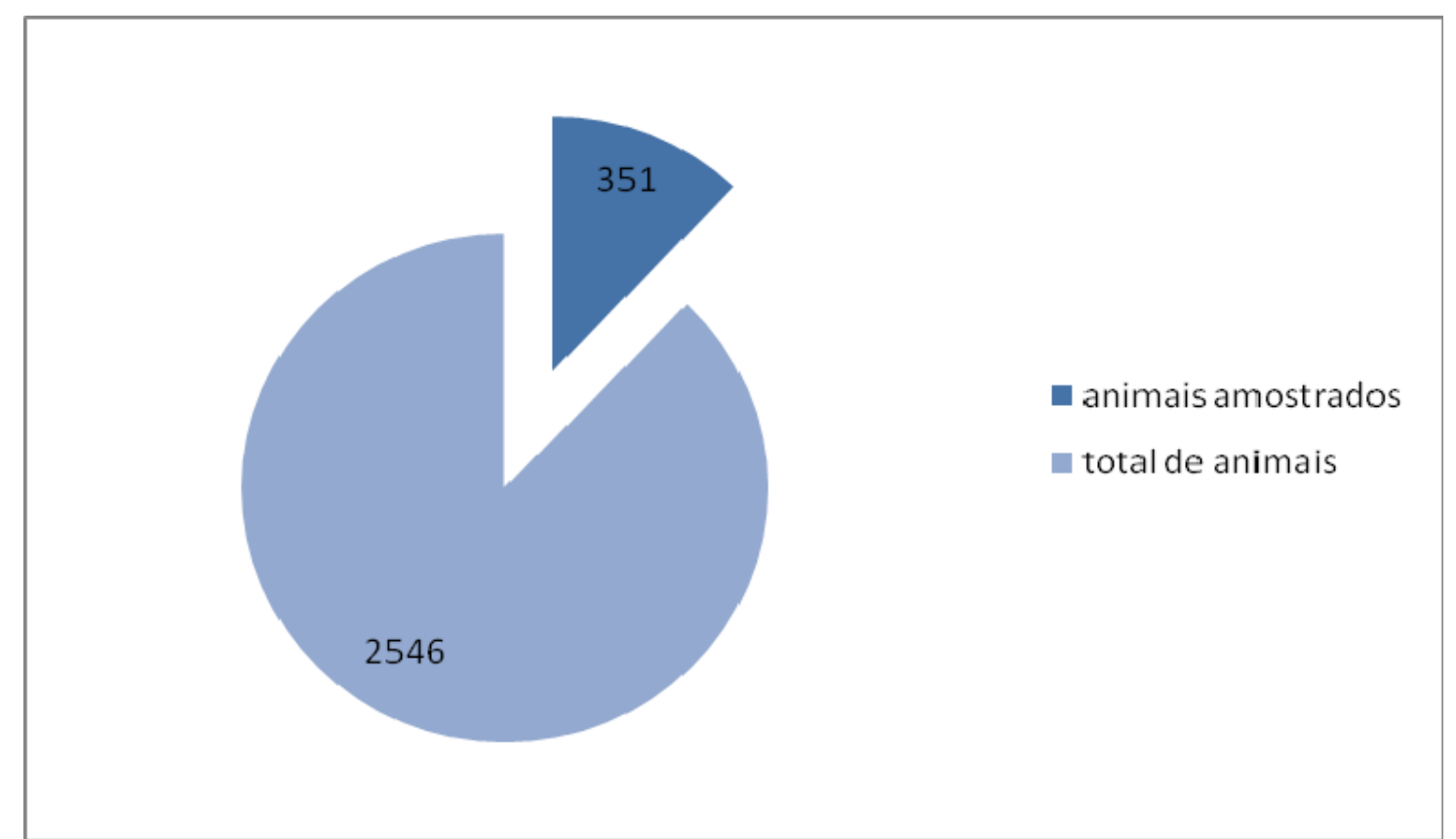

Figura 13 - Quantidade de bovinos e número de animais amostrados no entorno dos remanescentes de mata Tucano, Ponte Branca, Água Sumida e Santa Maria (fragmentos grandes)

5.5.4 Mapas da distribuição de animais domésticos

Os mapas abaixo indicam o intervalo da quantidade das espécies animais domésticos no entorno de cada fragmento de mata.

Os eqüinos são animais utilizados para trabalho na propriedade, não havendo um elevado número de animais nas propriedades. Os eqüinos são vacinados em algumas propriedades da região apenas para encefalomielite eqüina.

No mapa 1 abaixo, pode-se observar a distribuição e quantidade de eqüinos no entorno dos fragmentos do Pontal do Paranapanema. 


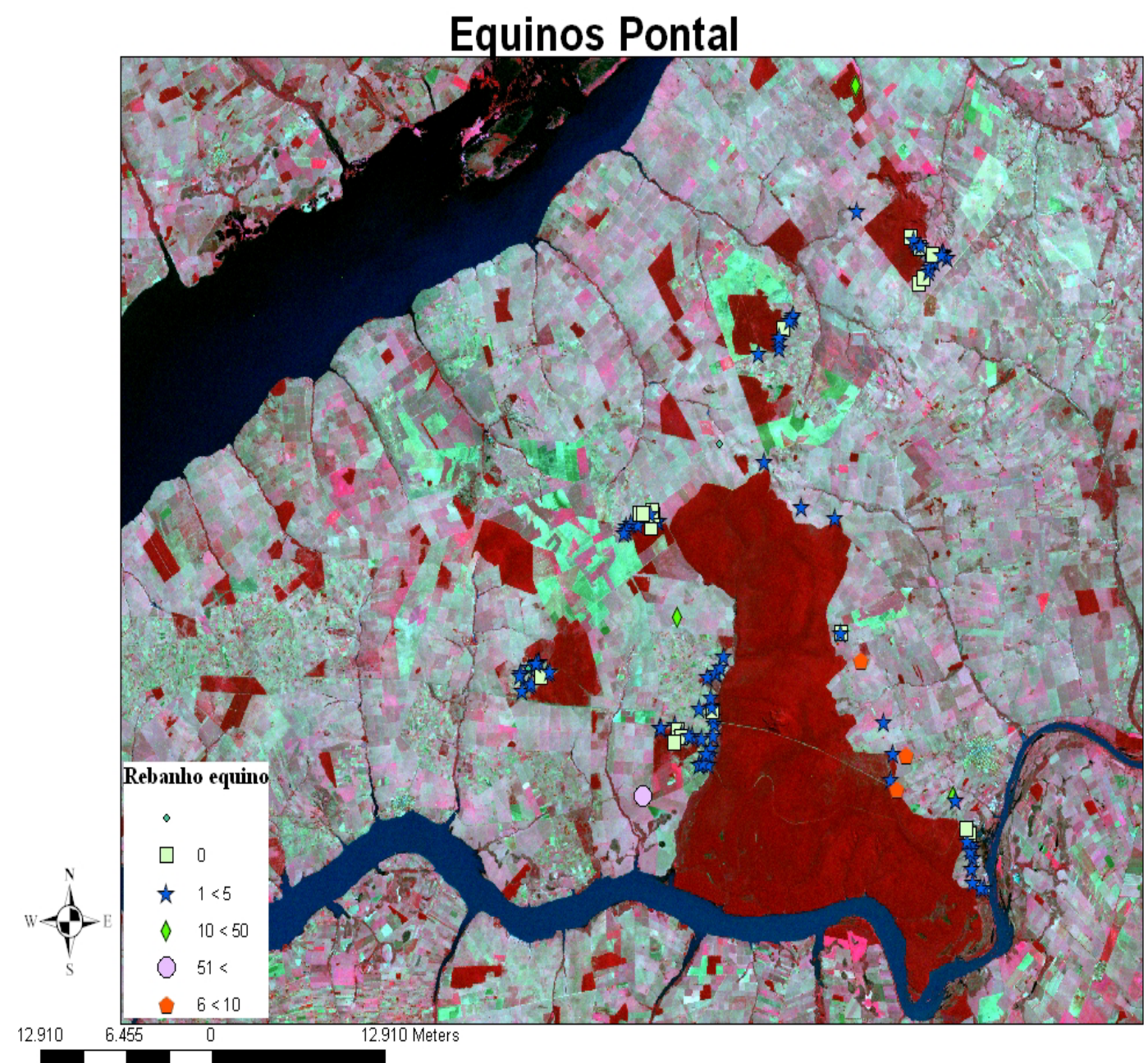

Mapa 1 - Distribuição de eqüinos no entorno dos fragmentos florestais do Pontal do Paranapanema

Os bovinos têm uma distribuição mais uniforme que os eqüinos. A face oeste do PEMD tem o predomínio do assentamento rural Ribeirão Bonito e a sudoeste a fazenda Rosanella. Nota-se que a quantidade de bovinos é maior na fazenda Rosanella do que nas propriedades do assentamento. Os pontos vermelhos e os pontos azuis claros no mapa 2 abaixo são os que demonstram os intervalos mais elevados na quantidade de bovinos, sendo coincidentes com as fazendas extensivas de gado de corte. 


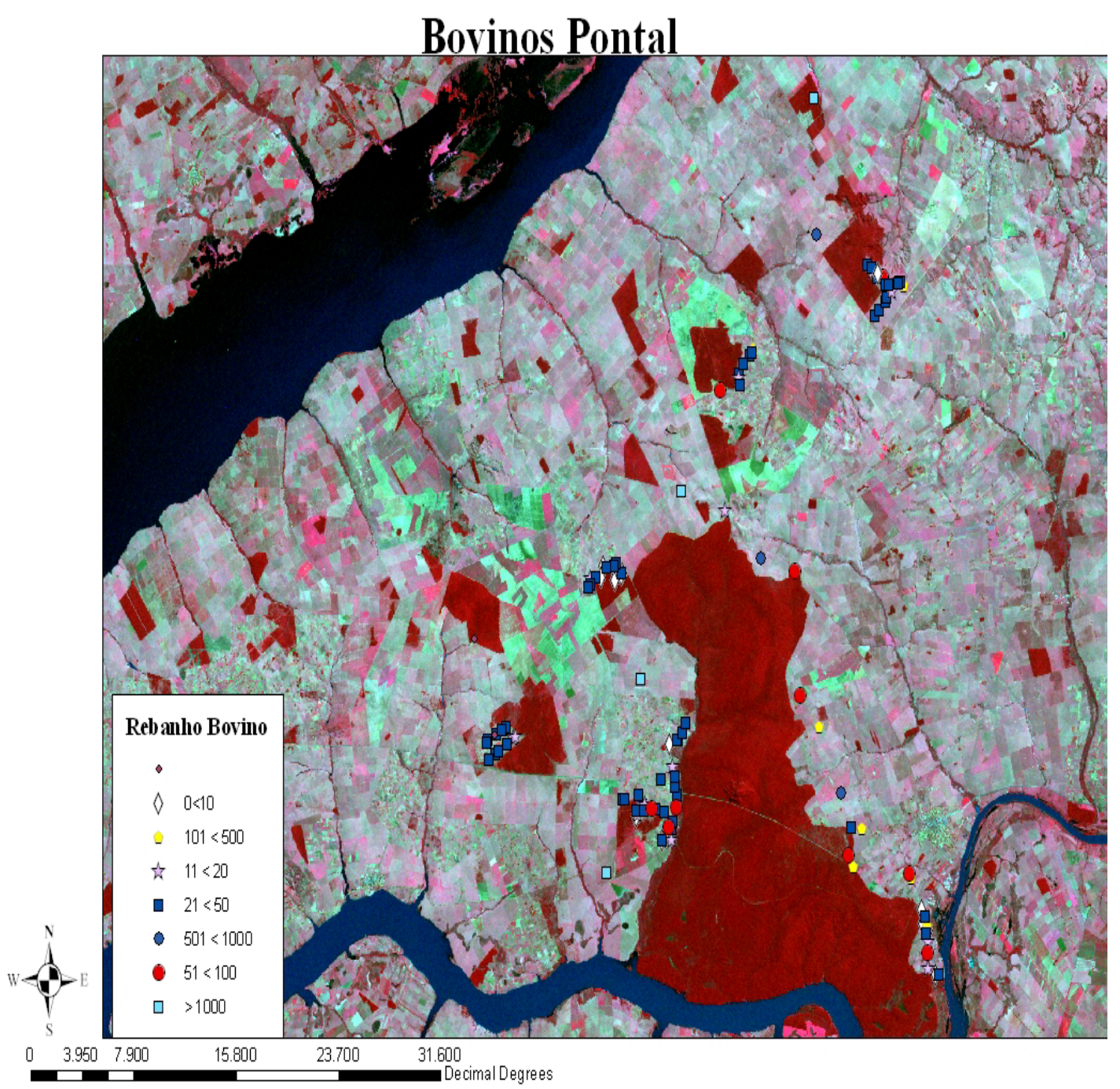

Mapa 2 - Distribuição de bovinos nos fragmentos florestais do Pontal do Paranapanema

Notamos que a paisagem no entorno do PEMD é mais heterogênea que ao redor dos diversos fragmentos florestais. Essa paisagem é resultado da existência de diferentes modos de produção das propriedades do entorno do PEMD com sítios, assentamentos e fazendas. Nos bovinos o esquema de vacinação que persiste em praticamente todas as propriedades é vacinação para febre aftosa e brucelose.

Os suínos são animais que não persistem muito tempo nas propriedades, sendo vendidos e comprados com muita freqüência, pois são utilizados como fonte de subsistência nestas propriedades. Não é aplicado nenhum tipo de vacina nesses animais, sendo aplicado ivermectina um dia antes do abate ou durante gestação. Em apenas dois sítios no entorno do PEMD havia criação com mais de 50 animais. No mapa 3 abaixo, a distribuição e quantidade de suínos no entorno dos fragmentos de mata do estudo. 


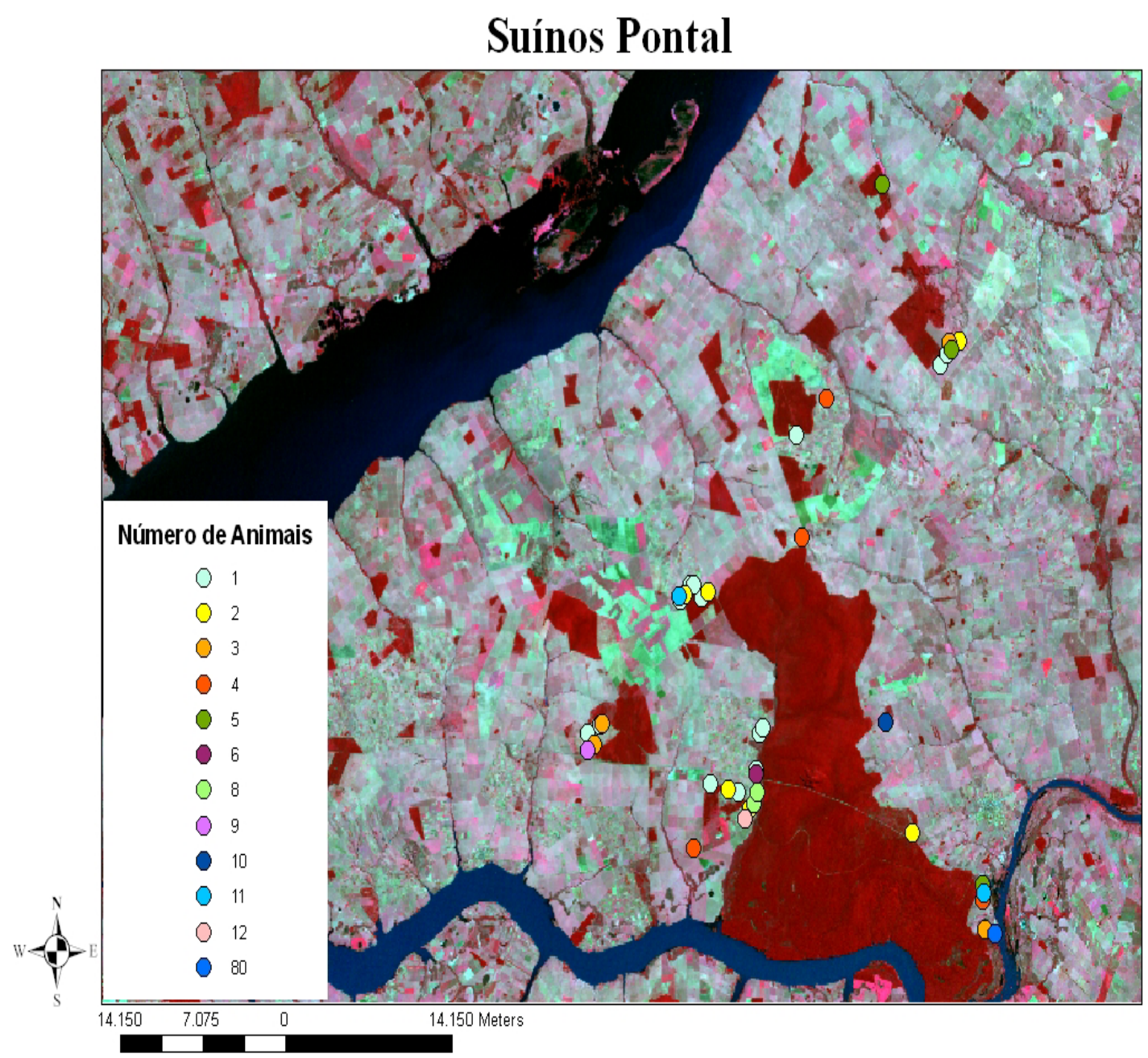

Mapa 3 - Distribuição de suínos no entorno dos fragmentos de floresta do Pontal do Paranapanema

Não há programa de esterilização de cães e gatos na região, sendo a população de animais errantes alta e a vacinação efetiva apenas anti-rábica.

Os cães, que vivem no entorno dos fragmentos, regularmente entram nas áreas de mata para caçar, demarcar território, ou acompanhar o dono nas caçadas. No mapa 4 abaixo, a distribuição e quantidade de caninos na paisagem fragmentada do Pontal. 


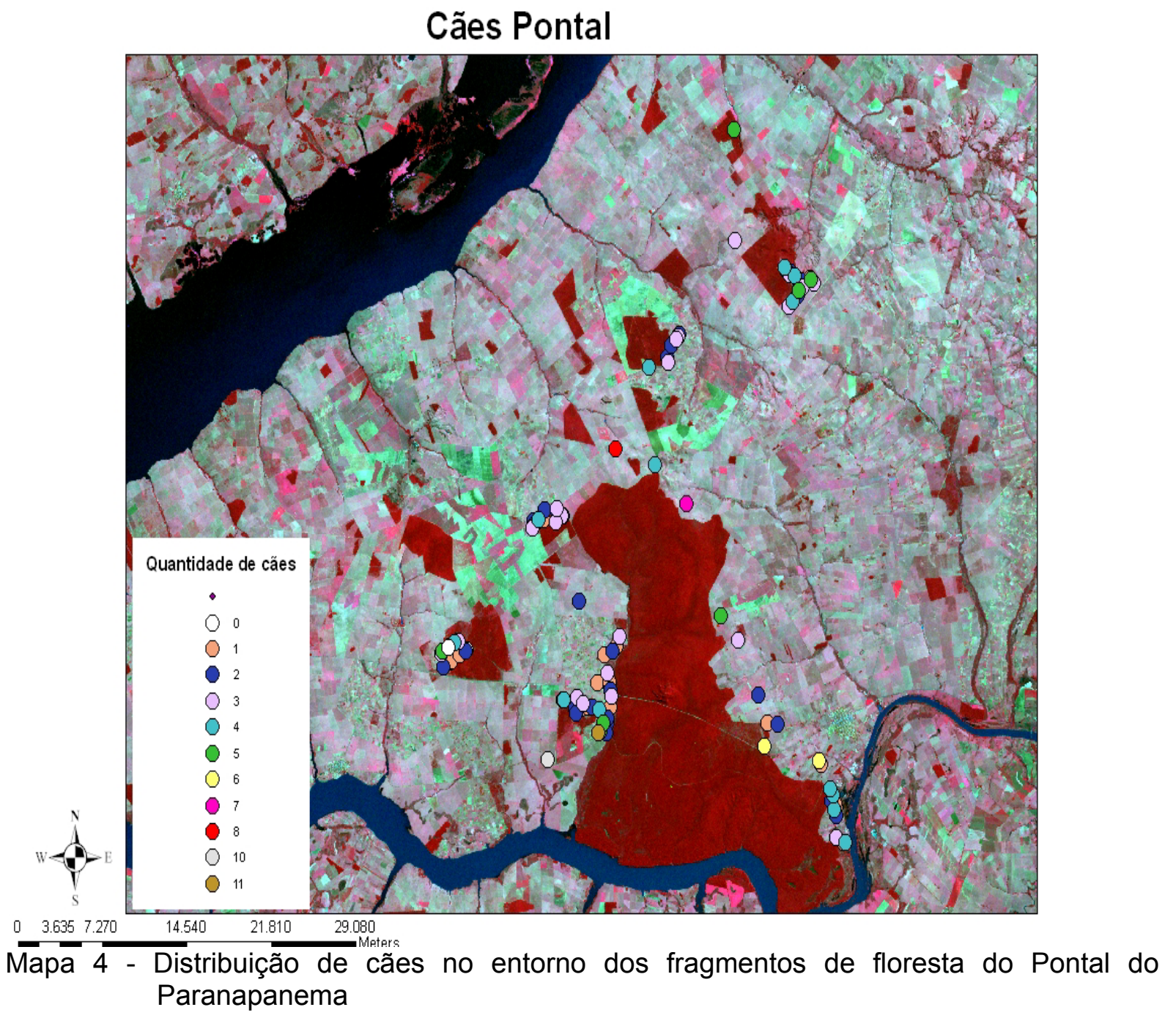

\subsection{CINOMOSE}

Nesta seção encontram-se os resultados do sorodiagnóstico de caninos e felídeos silvestres amostrados para cinomose. 
Foram coletadas 13 amostras de sangue de felídeos de vida livre. Essas amostras foram coletadas dos animais provenientes do Parque Estadual Morro do Diabo (onças pintadas $n=8$, onças pardas $n=2$ e jaguatiricas $n=4$ ).

Não houve nenhum felídeo reagente para cinomose amostrados no Parque Estadual Morro do Diabo. Os taiassuídeos capturados no Parque Estadual Morro do Diabo e nos fragmentos de floresta $(n=100)$ não apresentaram titulação para cinomose. As amostras foram analisadas atravéz do método diagnóstico soroneutralização lenta.

No mapa 5 a seguir estão sinalizados os locais de captura das onças pintadas e locais de amostragem dos caninos reagentes e não reagentes para cinomose: 


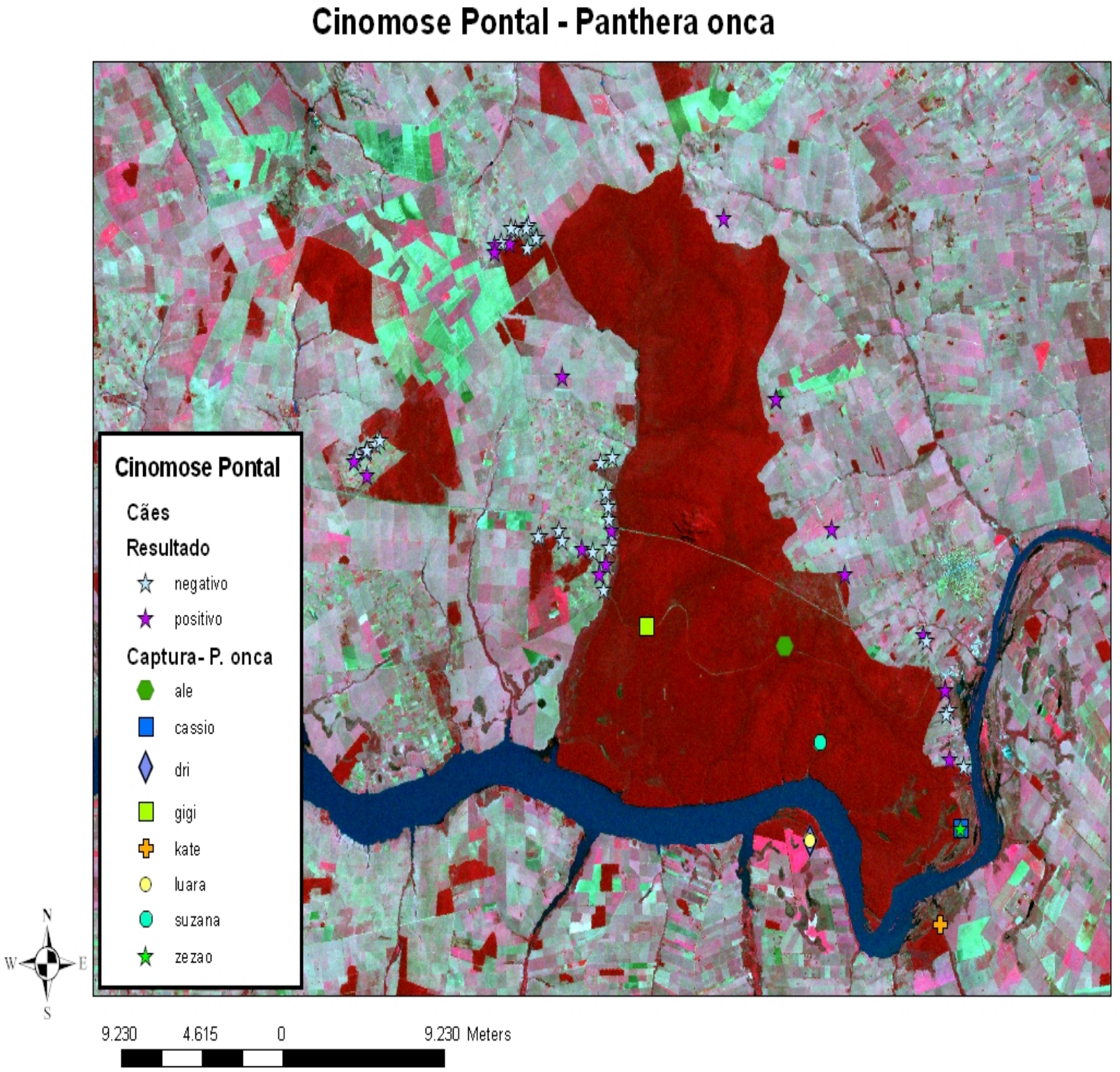

Mapa 5 - Local de amostragem de cães e onças pintadas amostrados para cinomose no Pontal do Paranapanema

5.6.2 Animais domésticos

Nenhum cão é vacinado contra cinomose em todo o entorno dos fragmentos de floresta. Mesmo na cidade mais próxima, são raros os animais que são vacinados. 
Dentre os cães amostrados do entorno do PEMD, Tucano e Santa Zélia ( $\mathrm{n}=$ $200)$, obtivemos $(n=12)$ indivíduos reagentes, ou seja, $(6 \%)$. No quadro 12 abaixo, a titulação para cinomose dos caninos do Pontal do Paranapanema através da soroneutralização lenta.

\begin{tabular}{|cc|}
\hline Espécie & Titulação \\
\hline Canino & $1: 128$ \\
\hline Canino & $1: 128$ \\
\hline Canino & $1: 128$ \\
\hline Canino & $1: 128$ \\
\hline Canino & $1: 128$ \\
\hline Canino & $1: 256$ \\
\hline Canino & $1: 256$ \\
\hline Canino & $1: 256$ \\
\hline Canino & $1: 256$ \\
\hline Canino & $1: 32$ \\
\hline Canino & $1: 32$ \\
\hline Canino & $1: 512$ \\
\hline
\end{tabular}

Quadro 12 - Titulação para cinomose (ponto de corte 1:16)

No mapa 6 abaixo, a distribuição na paisagem fragmentada do Pontal de cães reagentes e não reagentes para cinomose. 


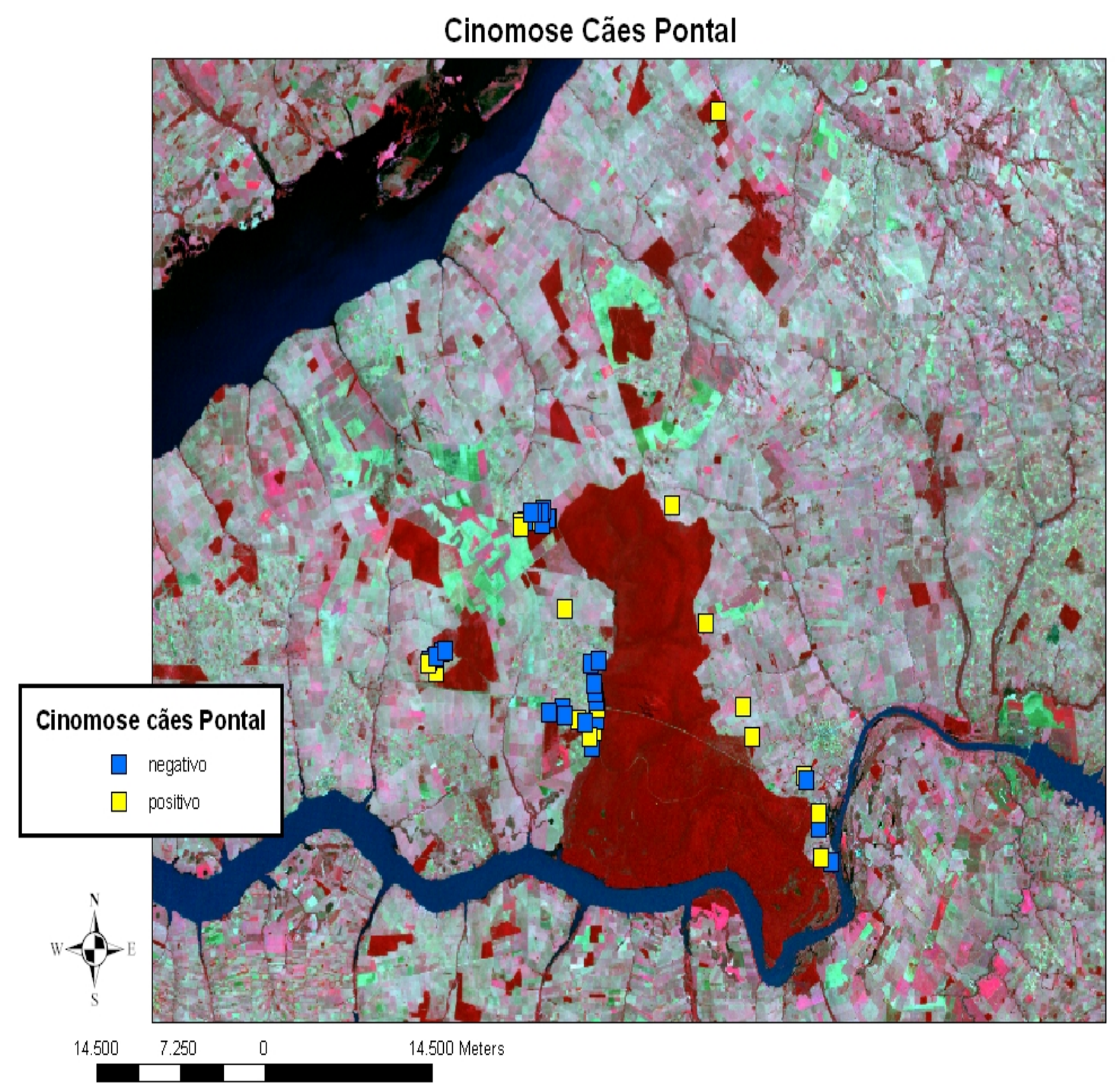

Mapa 6 - Cães amostrados para cinomose reagentes e não reagentes no Pontal do Paranapanema

\subsection{LEPTOSPIROSE}

Nesta seção, os resultados de animais reagentes e não reagentes para leptospirose e os sorovares prováveis encontrados em cada espécie divididos por localidade. 
5.7.1 Animais silvestres

Os queixadas do PEMD apresentaram maior número de animais reagentes para leptospirose do que os queixadas dos fragmentos Santa Mônica (fragmento pequeno) e Ponte Branca (fragmento grande) como mostra a figura 14 abaixo.

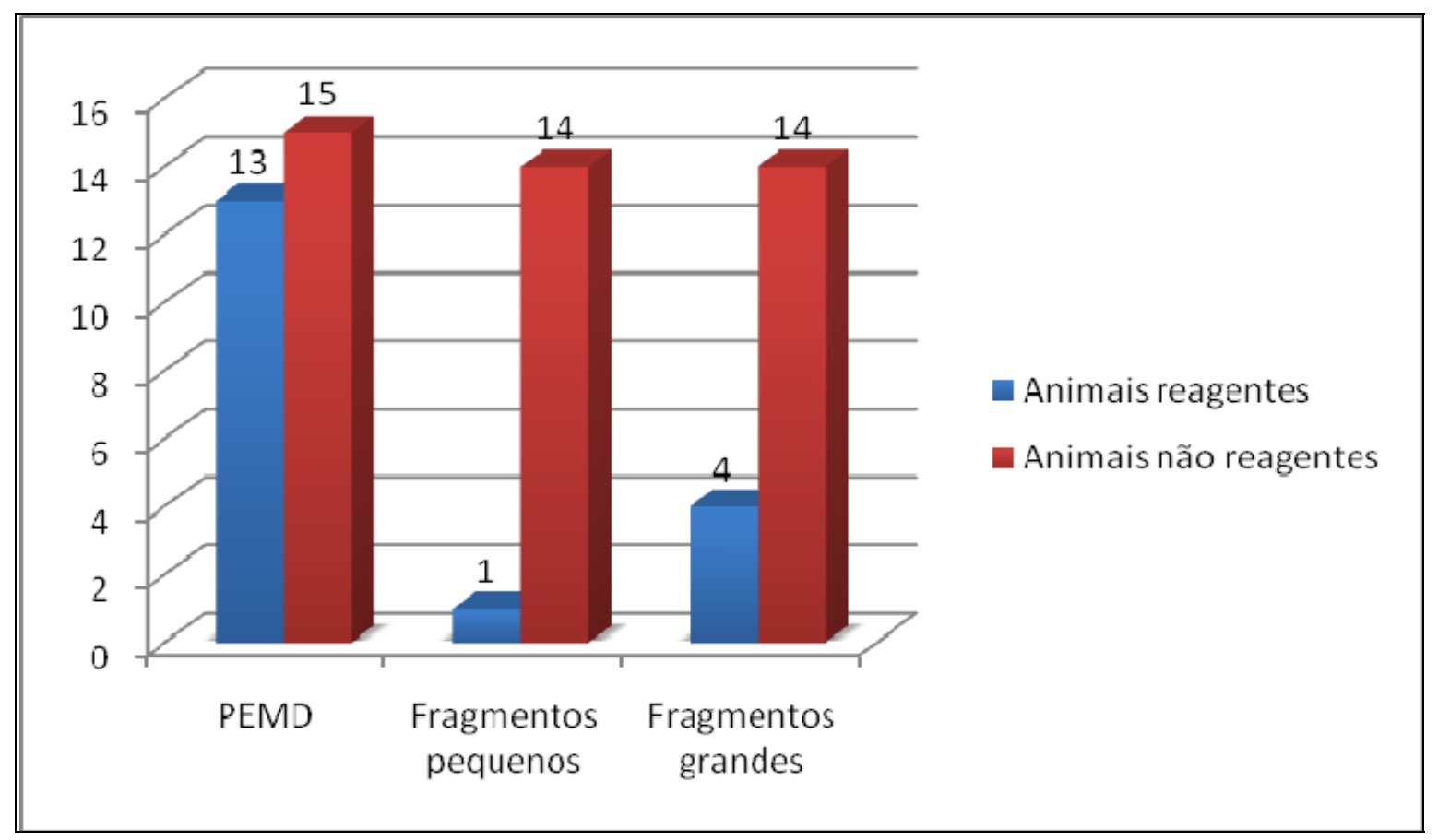

Figura 14 - Queixadas amostrados no Pontal do Paranapanema mostrando quantidade de indivíduos reagentes e não reagentes para leptospirose nos grupos de fragmentos

Comparando-se o número de animais reagentes nos três diferentes grupos: PEMD, fragmento grande e fragmento pequeno, nota-se que há diferença significativa na diferença no número de animais reagentes entre os três grupos, valor de $\chi^{2}=0.018$.

Comparando-se o número de queixadas reagentes capturados nos fragmentos grandes e pequenos e no PEMD, foi observada diferença significativa entre os dois grupos, valor de $\chi^{2}=0.016$.

Dos catetos amostrados no PEMD e fragmentos, apenas 4 indivíduos apresentaram anticorpos para leptospirose. Na figura 15 abaixo, os catetos reagentes e não reagentes para leptospirose nos três diferentes grupos de florestas (PEMD, fragmentos pequenos e fragmentos grandes): 


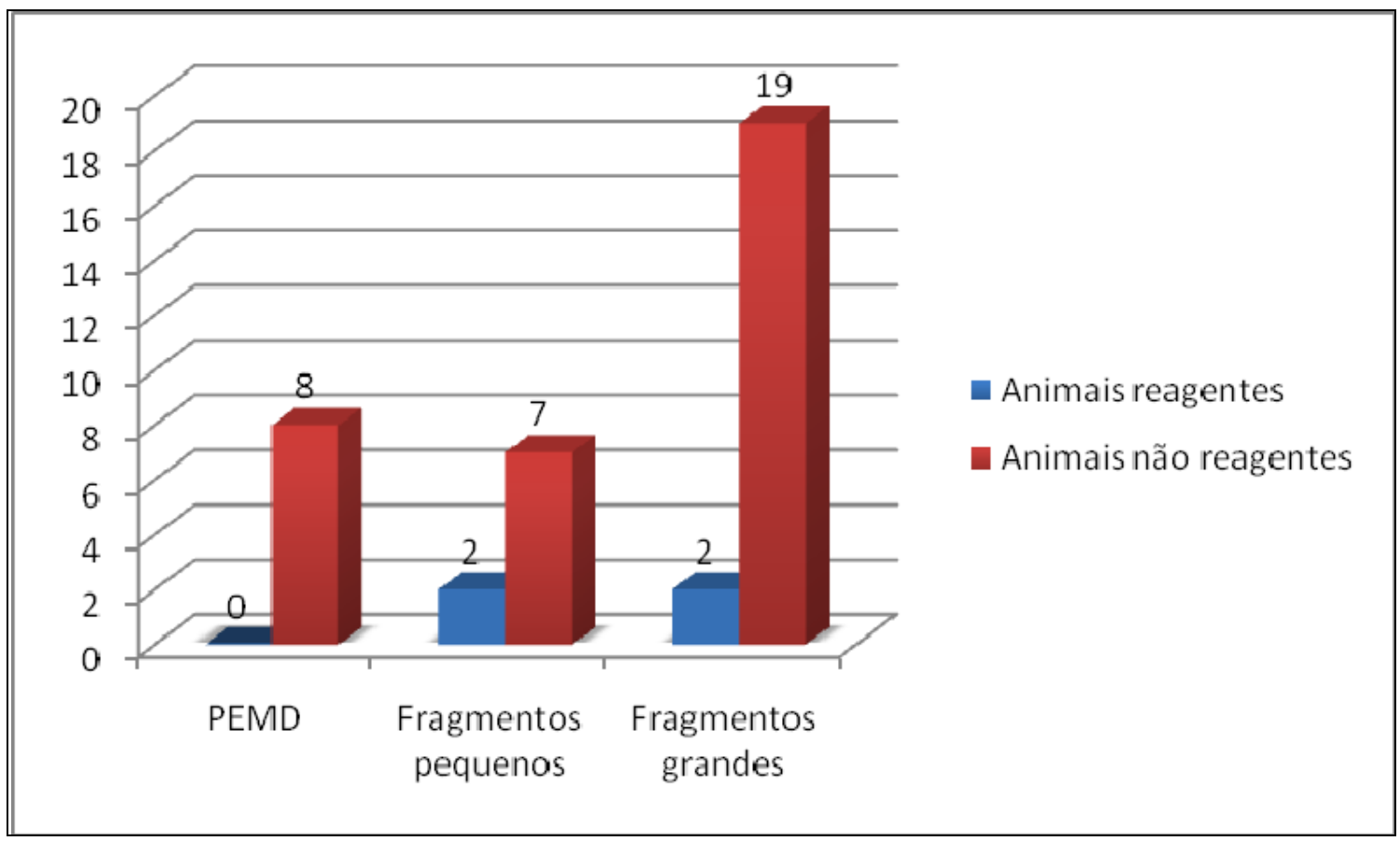

Figura 15 - Catetos amostrados no Pontal do Paranapanema mostrando quantidade de indivíduos reagentes e não reagentes para leptospirose nos diferentes grupos de fragmentos

A diferença entre o número de catetos reagentes e não reagentes não foi significativa entre os três grupos $\left(\chi^{2}=0.5\right)$. Comparando-se o número de catetos amostrados no PEMD e fragmentos, não houve diferença significativa (teste exato de Fisher $=0.65$ ). Dois catetos apresentaram título para o sorovar patoc, ambos capturados no fragmento Tucano e o único cateto positivo capturado no PEMD não foi reagente. O cateto capturado no fragmento Ribeirão Bonito apresentou título para o sorovar pyrogenes.

Dentre as 8 onças pintadas amostradas, apenas um animal macho adulto foi reagente para Leptospira pomona. As onças pardas e jaguatiricas deste estudo não foram reagentes para leptospirose. Na figura 16 abaixo, as onças pintadas, jaguatiricas e onça pardas amostradas para leptospirose: 


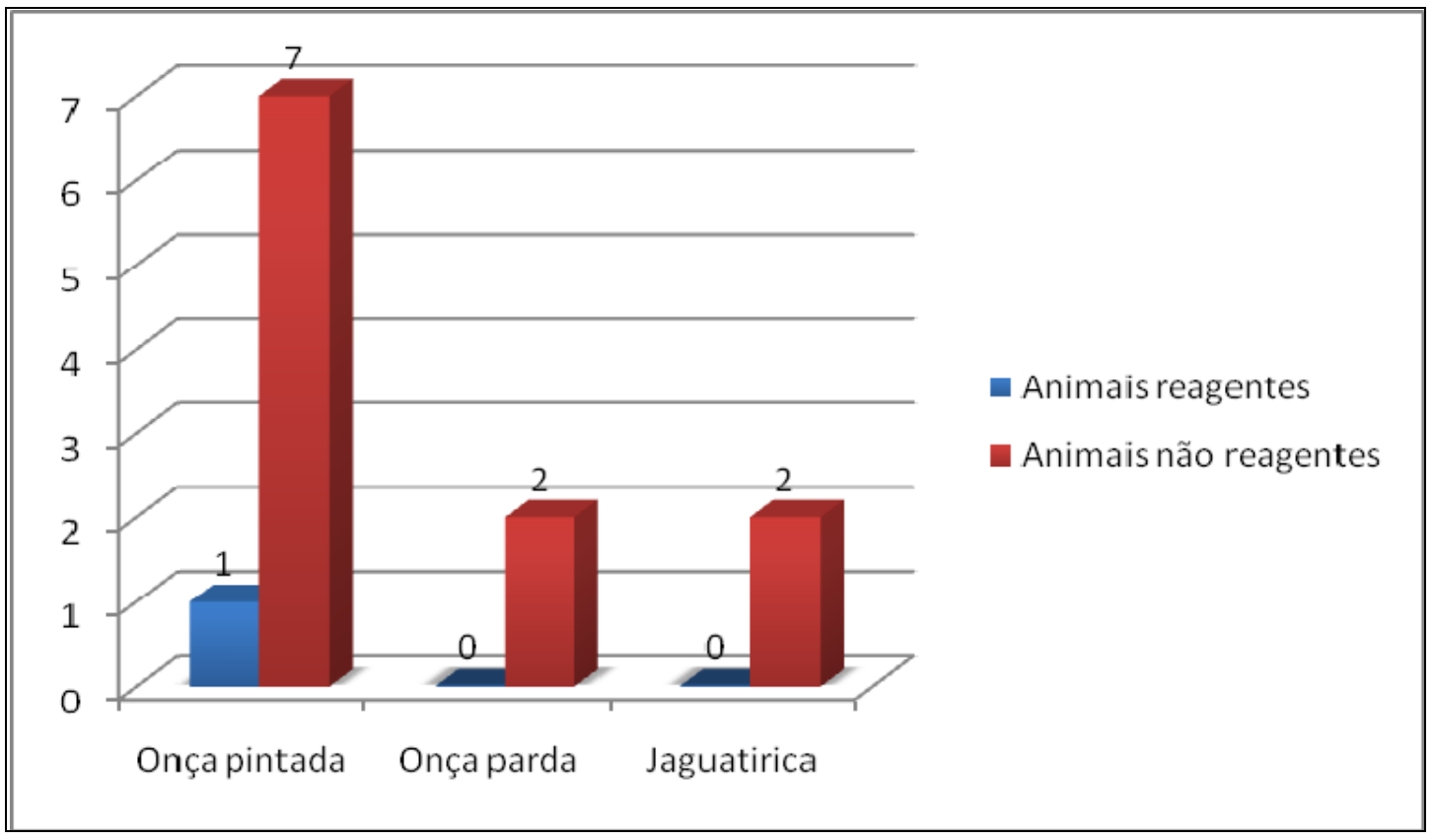

Figura 16 - Felídeos reagentes e não reagentes para leptospirose

No quadro 13 abaixo, os sorovares mais prováveis encontrados em animais silvestres nos diferentes grupos de fragmentos:

\begin{tabular}{|lccc|} 
& Fragmentos & Fragmentos & PEMD \\
pequenos & grandes & \\
\hline Cateto & Pyrogenes & Seramanga patoc & - ------------ \\
& pyrogenes & & \\
\hline Queixada & Panama & Icterohaemorrhagiae & Pomona \\
& panama & Icterohaemorrhagiae IV & pomona \\
& & & Pomona \\
\hline Onça Pintada & $-------------~$ & $-------------~$ & pomona \\
& & & \\
\hline
\end{tabular}

Quadro 13 - Sorovares mais prováveis em animais silvestres nos três grupos de fragmentos. 
5.7.2 Animais domésticos

Na figura 17 abaixo, o número de bovinos reagentes e não reagentes para leptospirose entre os grupos PEMD, fragmentos pequenos e fragmentos grandes:

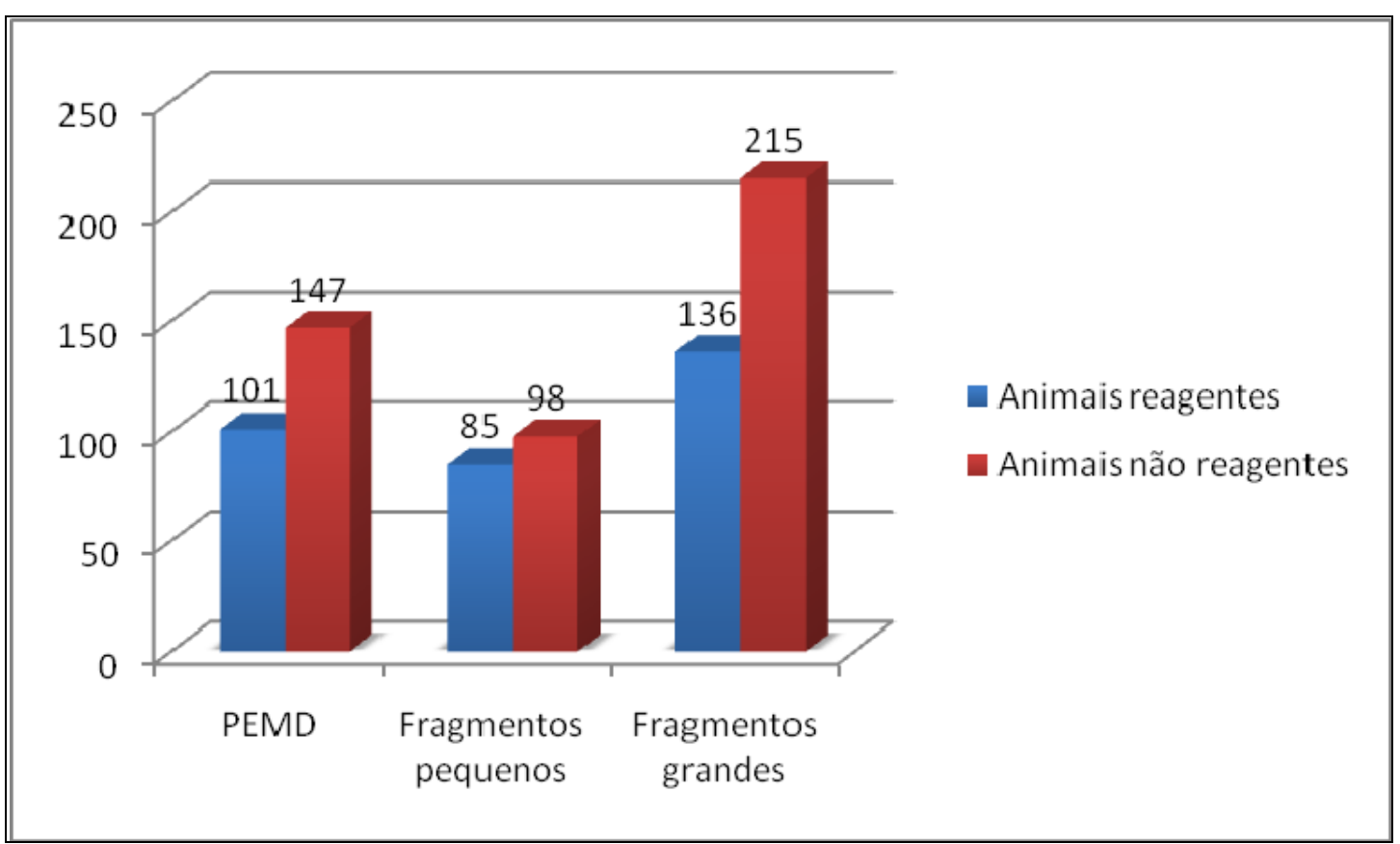

Figura 17- Bovinos reagentes e não reagentes para leptospirose nos diferentes grupos dos fragmentos de estudo

Não se detectou diferença estatisticamente significativa entre as proporções de bovinos com sorologia positiva para leptospirose entre os diferentes grupos $\left(\chi^{2}=\right.$ 0.22). Agrupando os bovinos reagentes e não reagentes para leptospirose do entorno dos fragmentos e comparando com os bovinos reagentes e não reagentes para leptospirose do entorno do PEMD, não foi encontrada diferença significativa entre os grupos (teste exato de Fisher=0.92).

Na figura abaixo, os caninos regentes e não reagentes para leptospirose no entorno dos diferentes grupos (PEMD, fragmentos pequenos e fragmentos grandes): 


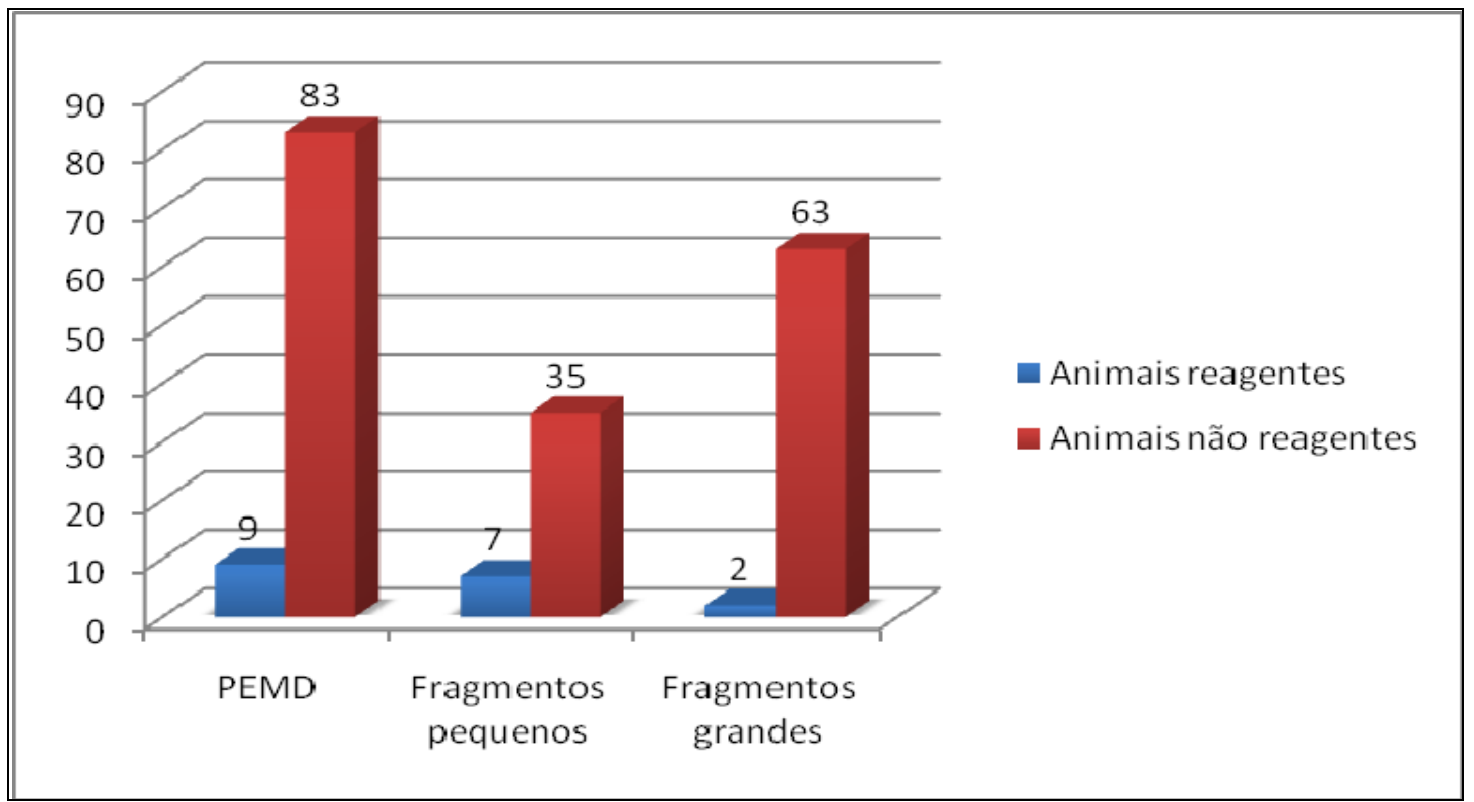

Figura 18 - Caninos reagentes e não reagentes para leptospirose

Dentre os caninos reagentes entre os três grupos, houve diferença significativa entre os caninos com sorologia para leptospirose entre os diferentes grupos $\left(\chi^{2}=0.048\right)$. Comparando-se o grupo PEMD e fragmentos, não houve diferença significativa (teste exato de Fisher $=0.92$ ).

Na figura 19 abaixo, os ovinos reagentes não reagentes para leptospirose no entorno dos diferentes grupos (PEMD, fragmentos pequenos e fragmentos grandes):

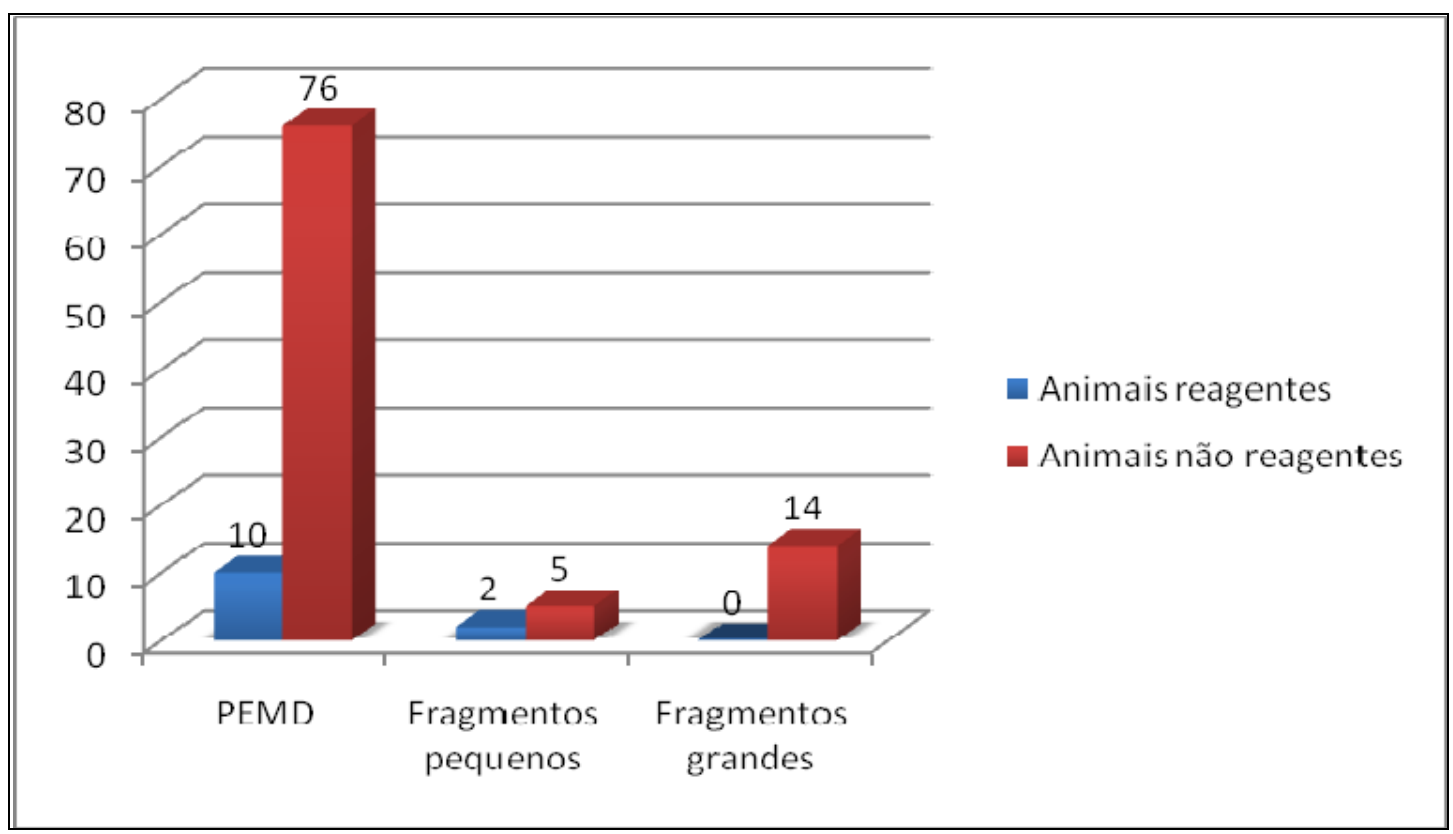

Figura 19 - Ovinos reagentes e não reagentes para leptospirose nos diferentes grupos 
Não se detectou diferença estatisticamente significativa entre as proporções de animais com sorologia positiva para leptospirose entre os três diferentes grupos $\left(\chi^{2}=0.125\right)$. Na comparação entre ovinos reagentes no entorno dos fragmentos e PEMD, também não houve diferença estatisticamente significativa (teste exato de Fisher $=0.91)$.

A figura 20 abaixo mostra os números de suínos reagentes não reagentes para leptospirose no entorno dos diferentes grupos (PEMD, fragmentos pequenos e fragmentos grandes):

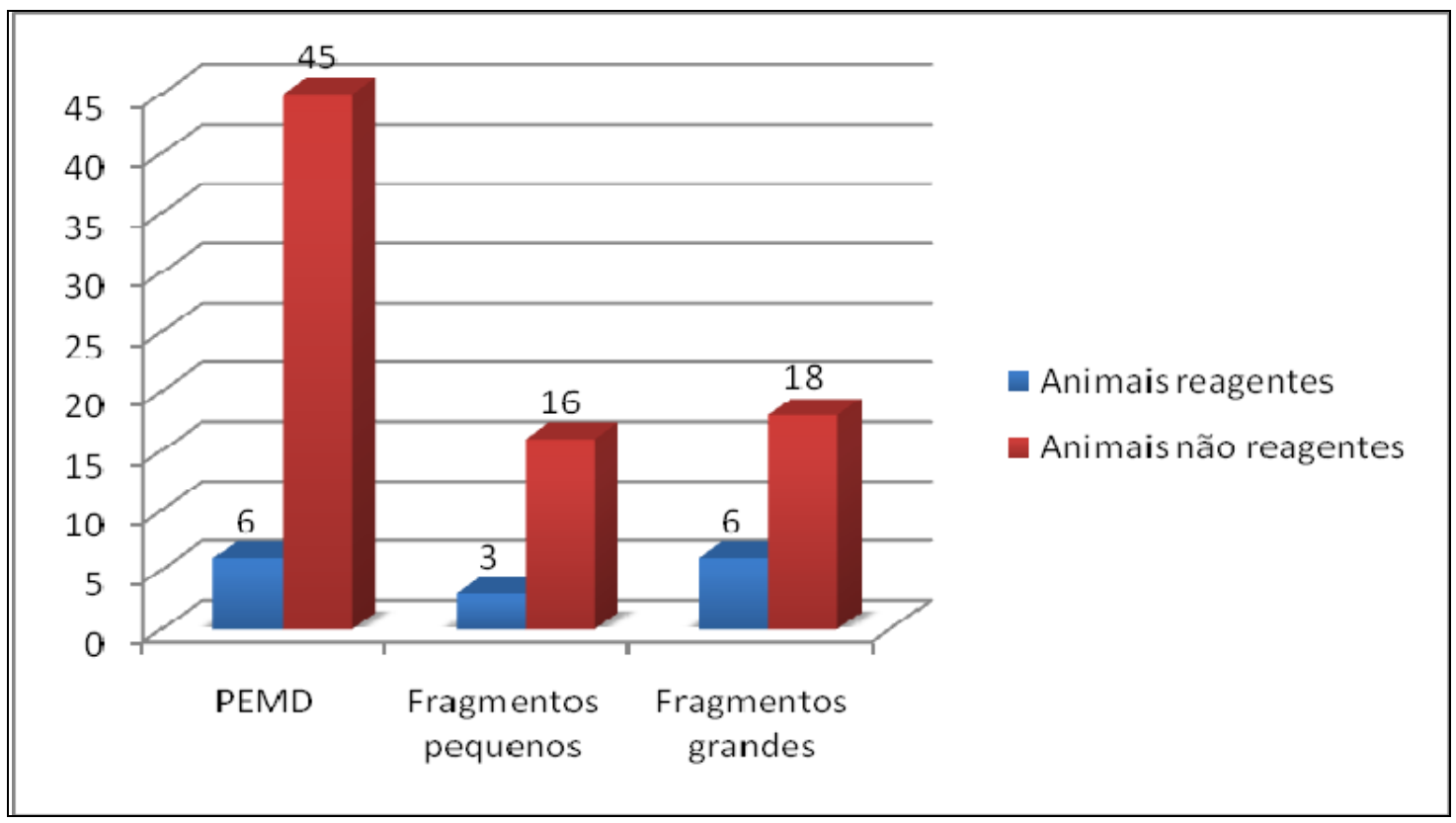

Figura 20- Suínos reagentes e não reagentes para leptospirose nos diferentes grupos

Não se detectou diferença estatisticamente significativa entre as proporções de animais com sorologia positiva para leptospirose entre os três diferentes grupos $\left(\chi^{2}=0.33\right)$. Comparando-se o número de suínos reagentes e não reagentes para leptospirose no entorno do PEMD e fragmentos, também não houve diferença significativa entre os dois grupos (teste exato de Fisher $=0.35$ ).

Na figura 21 abaixo, os eqüinos reagentes e não reagentes para leptospirose nos diversos grupos de fragmentos: 


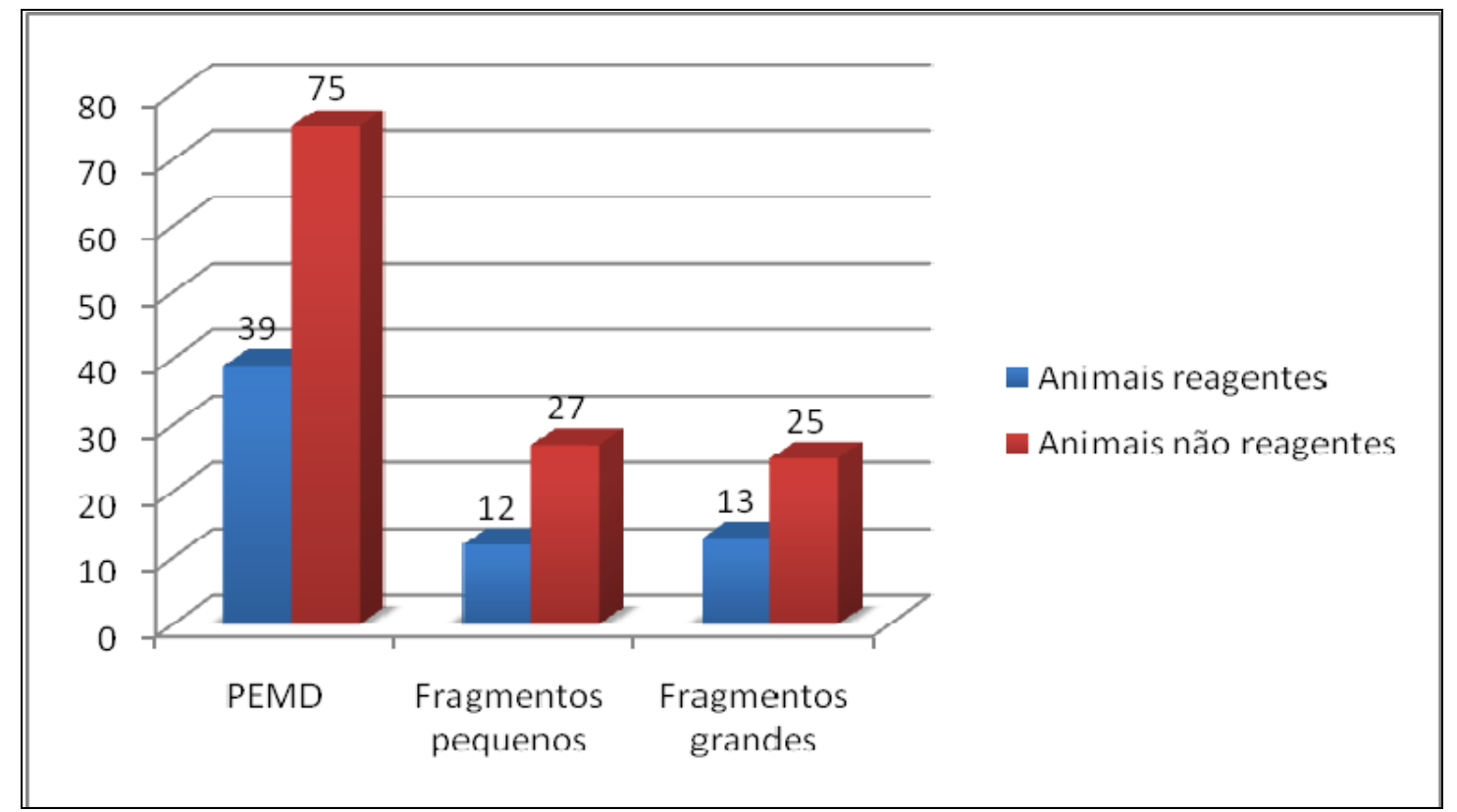

Figura 21- Equinos reagentes e não reagentes para leptospirose nos diferentes grupos

Não se detectou diferença estatisticamente significativa entre as proporções de animais com sorologia positiva para leptospirose entre os diferentes grupos (teste exato de Fisher $\left.\chi^{2}=0,95\right)$. Entre os eqüinos reagentes do PEMD e fragmentos, também não houve diferença estatisticamente significativa (teste exato de Fisher= $0,92)$.

Foram capturados dentro das propriedades vizinhas do entorno $n=100$ ratos sinantrópicos, identificados como Ratus rattus, sendo que todos animais não foram reagentes para leptospirose.

No quadro 14 abaixo, os sorovares mais prováveis encontrados nos animais domésticos amostrados no entorno dos diferentes grupos: 


\begin{tabular}{|c|c|c|c|}
\hline & $\begin{array}{l}\text { Fragmentos } \\
\text { pequenos }\end{array}$ & $\begin{array}{l}\text { Fragmentos } \\
\text { Grandes }\end{array}$ & PEMD \\
\hline Bovinos & $\begin{array}{c}\text { Sejroe hardjo; } \\
\text { Shermani shermani }\end{array}$ & $\begin{array}{c}\text { Sejroe hardjo; Sejroe } \\
\text { wolffi }\end{array}$ & Sejroe hardjo; \\
\hline Cães & Hardjobovis & Autumnalis autumnalis & Seramanga patoc \\
\hline Equinos & $\begin{array}{c}\text { Icterohaemorrhagiae } \\
\text { icterohaemorrhagiae } \\
\text { IV; Australis } \\
\text { batislava; } \\
\text { Hardjobovis }\end{array}$ & $\begin{array}{c}\text { Autumnalis autumnalis; } \\
\text { Icterohaemorrhagiae } \\
\text { Icterohaemorrhagiae } \\
\text { IV; Hardjobovis; } \\
\text { Seramanga patoc }\end{array}$ & $\begin{array}{l}\text { Autumnalis } \\
\text { autumnalis; }\end{array}$ \\
\hline Suínos & Australis batislava & $\begin{array}{c}\text { Icterohaemorrhagiae } \\
\text { copenhageni }\end{array}$ & Australis batislava \\
\hline Ovinos & castellonis & --------------- & $\begin{array}{l}\text { Autumnalis } \\
\text { autumnalis }\end{array}$ \\
\hline
\end{tabular}

Quadro 14 - Sorovares mais prováveis em animais domésticos nos três grupos de fragmentos

5.7.3 Animais domésticos e animais silvestres

$\mathrm{Na}$ figura 22 abaixo, o número de animais domésticos reagentes e não reagentes do entorno dos fragmentos pequenos e taiassuídeos reagentes e não reagentes capturados nos fragmentos pequenos. 


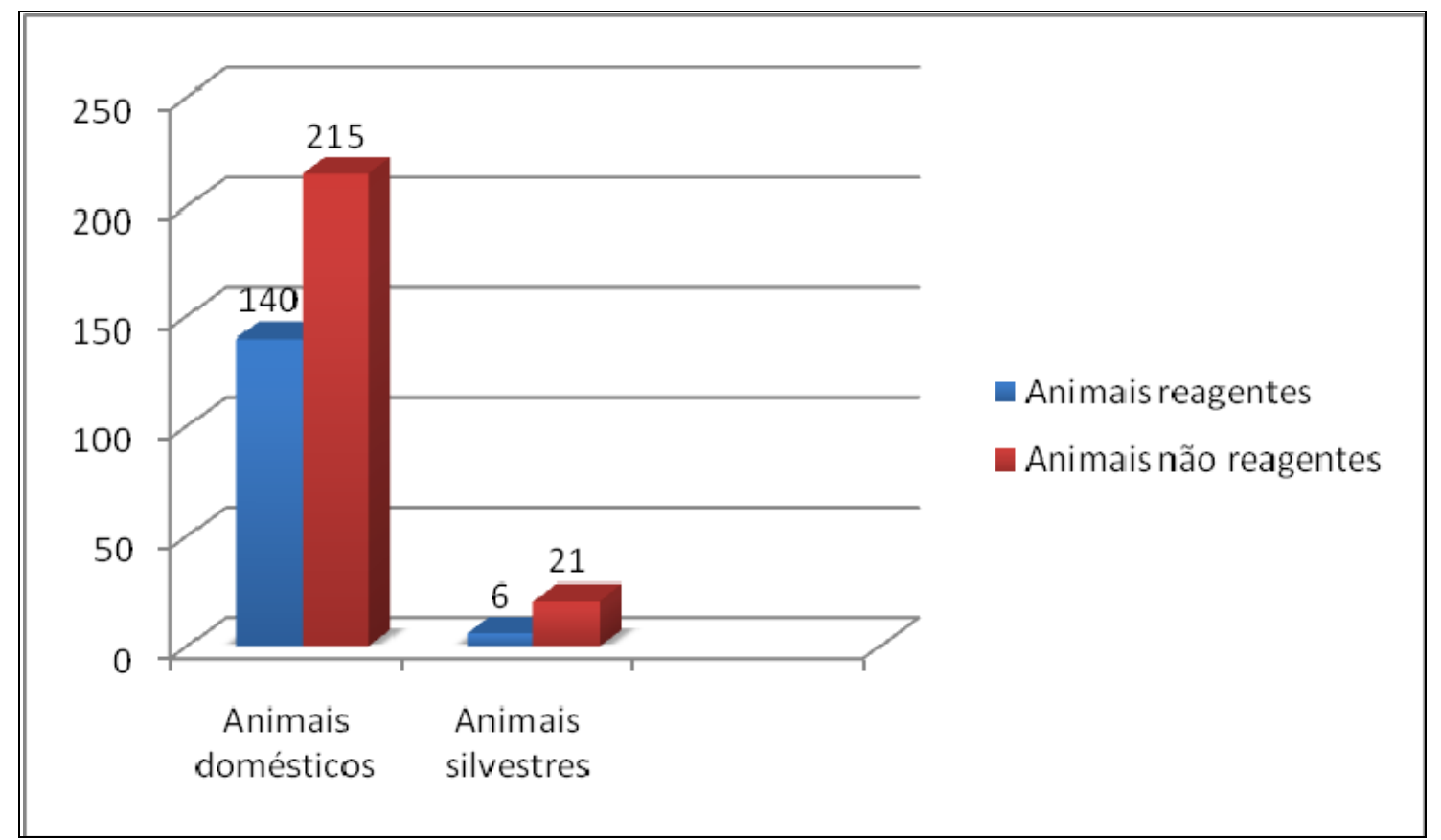

Figura 22 - Prevalência de leptospirose em taiassuídeos provenientes de fragmentos pequenos e animais e domésticos de seus entornos

Não houve diferença significativa entre os animais domésticos do entorno dos pequenos fragmentos e taiassuídeos amostrados nestes fragmentos florestais $\chi^{2}=$ 0.11. Na figura 23 abaixo, o número de animais domésticos reagentes e não reagentes no entorno dos fragmentos grandes e taiassuídeos reagentes e não reagentes amostrados nos fragmentos grandes:

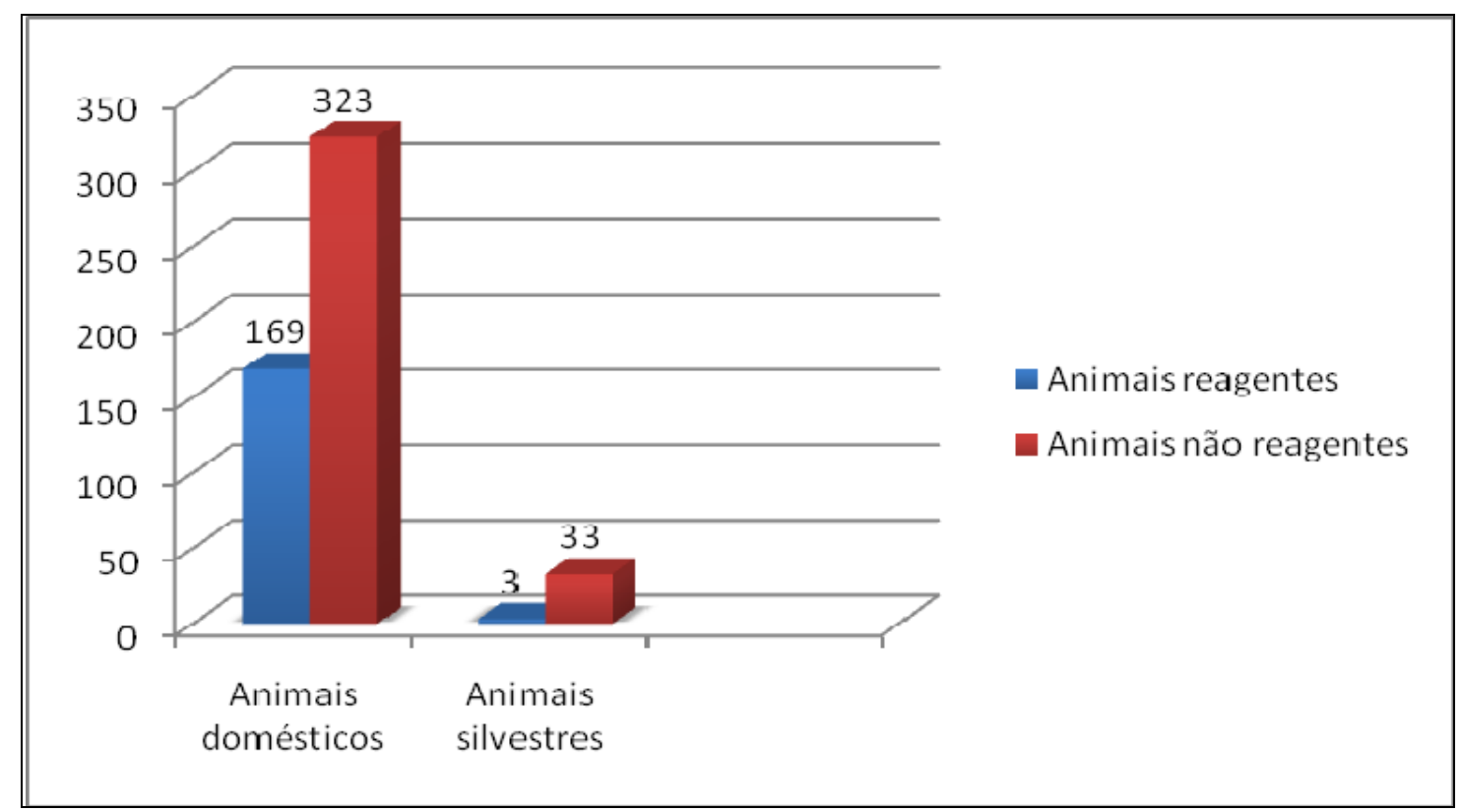

Figura 23 - Prevalência de leptospirose em taiassuídeos provenientes de fragmentos grandes e animais domésticos de seus entornos 
Houve diferença estatisticamente significativa entre os animais domésticos reagentes do entorno dos fragmentos grandes e taiassuídeos amostrados em grandes fragmentos $\chi^{2}=0.0024$.

Comparando taiassuídeos reagentes e não reagentes capturados em fragmentos grandes e pequenos e animais domésticos nos seus entornos, houve diferença estatisticamente significativa entre os dois grupos $\chi^{2}=0.0060$. Na figura 24 abaixo, os taiassuídeos reagentes e não reagentes para leptospirose amostrados no PEMD e animais domésticos reagentes e não reagentes para leptospirose amostrados no entorno do PEMD.

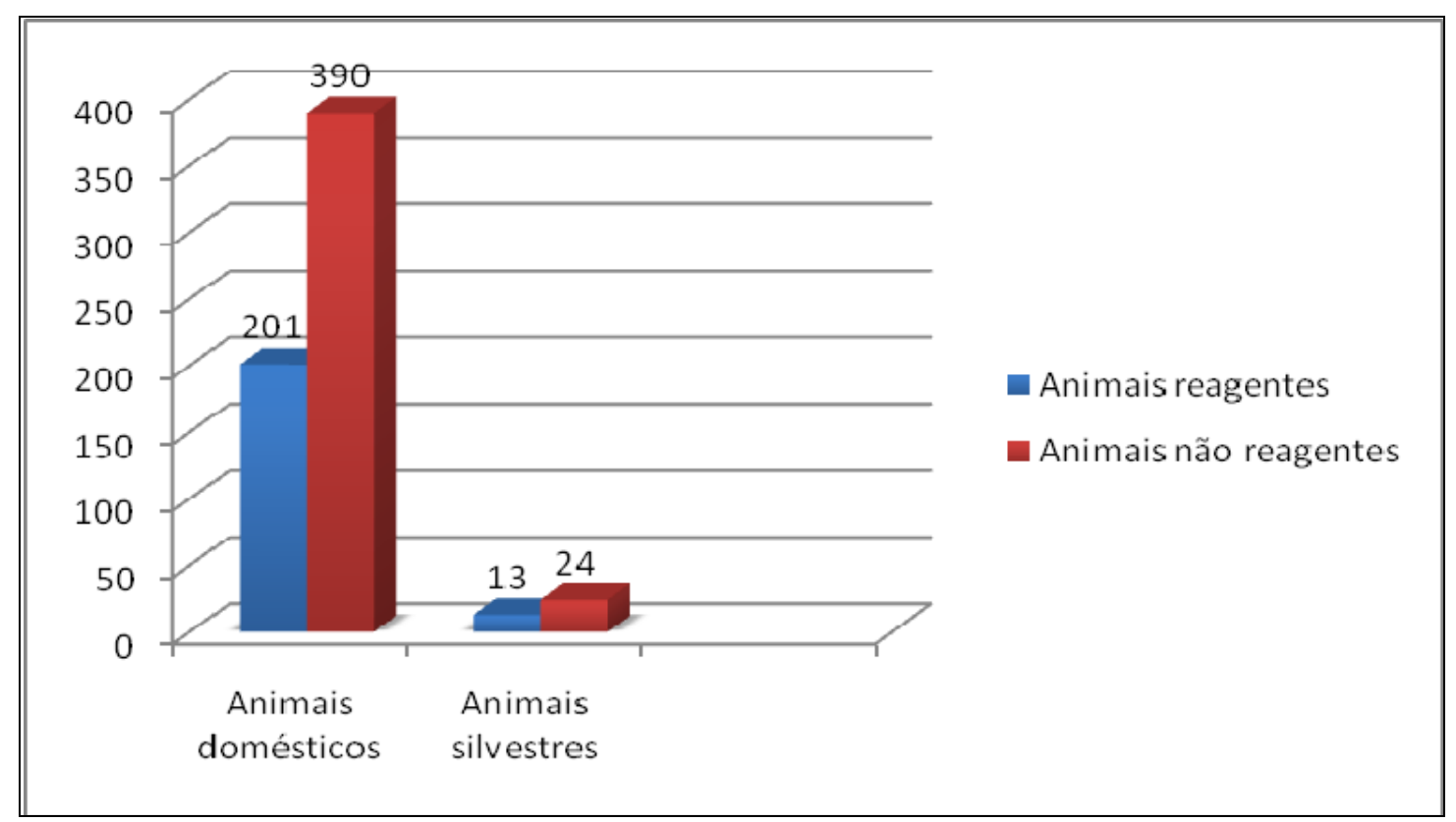

Figura 24 - Prevalência de leptospirose em taiassuídeos provenientes do PEMD e animais domésticos de seu entorno

Não houve diferença significativa entre os animais domésticos reagentes do entorno do PEMD e taiassuídeos reagentes amostrados no PEMD $\chi^{2}=0.96$.

Em todos os animais domésticos reagentes para leptospirose e animais silvestres amostrados foi realizada tentativa de isolamento para leptospirose, sendo que todas as culturas foram inconclusivas. 


\subsection{BRUCELOSE}

Nesta seção, os resultados dos animais reagentes e não reagentes para brucelose na paisagem fragmentada do Pontal

\subsubsection{Animais silvestres}

Dentre as oito onças pintadas amostradas, apenas um animal foi reagente. As onças pardas e jaguatiricas não foram reagentes para brucelose. Entre os queixadas amostrados no PEMD $(n=28)$, sete animais apresentaram anticorpos para Brucella spp e apenas um indivíduo do fragmento Ponte Branca $(n=15)$ foi reagente para brucelose como mostra a figura 25 abaixo.

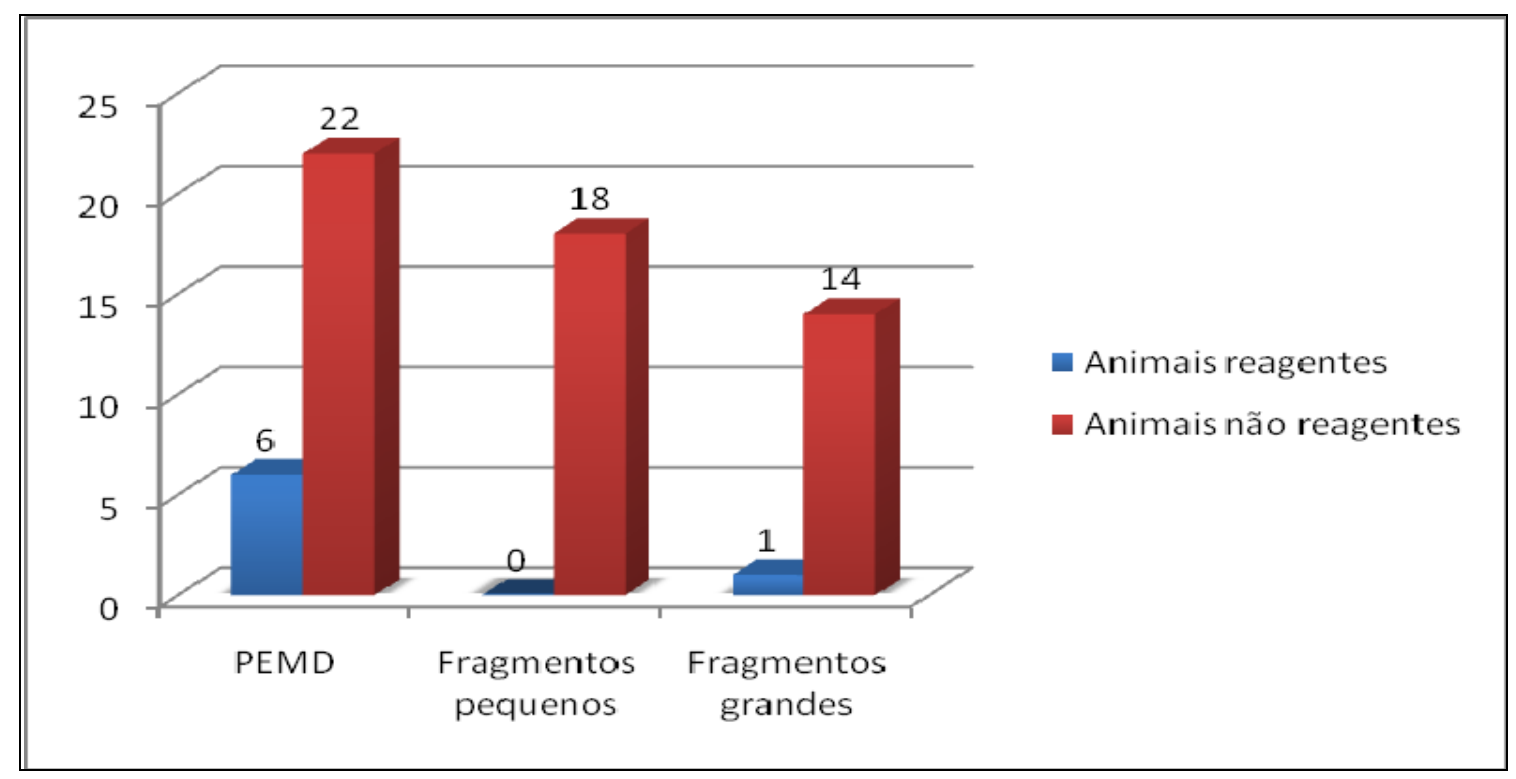

Figura 25 - Queixadas amostrados no PEMD, fragmento Ponte Branca (fragmento grande) e Santa Mônica (fragmento pequeno) para brucelose

Não houve diferença significativa entre o número de queixadas reagentes para brucelose nos três grupos $\chi^{2}=0.059$.

Agrupando os queixadas reagentes e não reagentes dos grupos fragmento grande e pequeno e, comparando com os queixadas amostrados no PEMD, não 
houve diferença significativa $\chi^{2}=0.065$. Dentre os 39 catetos amostrados nesse estudo, apenas um indivíduo capturado foi reagente para brucelose.

Este indivíduo foi capturado no PEMD em uma ceva localizada na borda do PEMD com o assentamento Ribeirão Bonito. Abaixo na figura 26 , os catetos reagentes para brucelose nos diversos grupos de floresta:

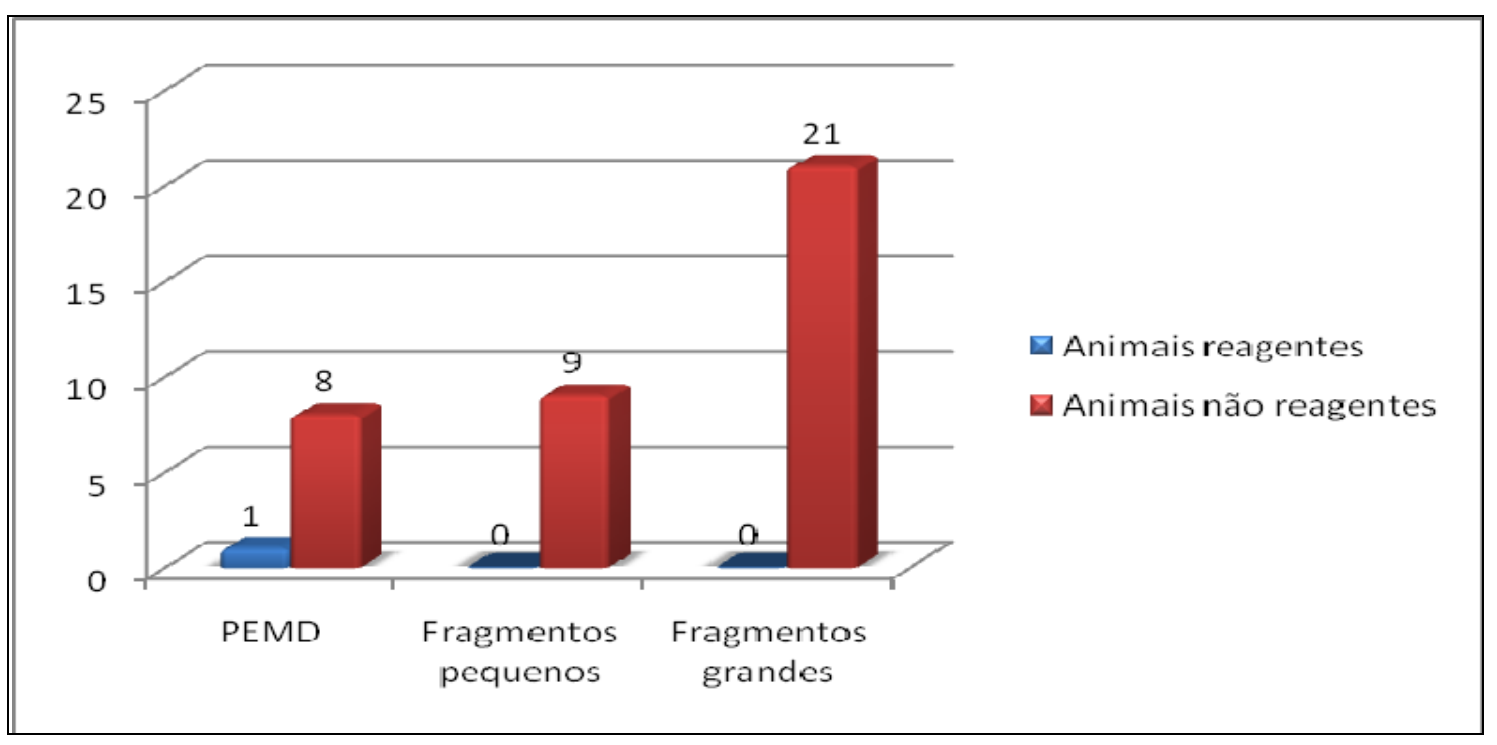

Figura 26 - Catetos amostrados para brucelose

Não houve diferença significativa entre os catetos reagentes e não reagentes para brucelose nos diferentes fragmentos florestais $\chi^{2}=0.46$. Agrupando os catetos reagentes e não reagentes dos grupos fragmento grande e pequeno e comparando com os catetos amostrados no PEMD, não houve diferença significativa $\chi^{2}=0.51$.

\subsubsection{Animais domésticos}

Dentre os 782 bovinos amostrados neste estudo para brucelose, 6 animais foram reagentes $(n=1$ animal no entorno do PEMD, $n=1$ no assentamento Santa Zélia e $n=4$ animais do assentamento Ribeirão Bonito no entorno do fragmento Ribeirão Bonito). Na figura 27 abaixo, os bovinos reagentes para brucelose nos entorno dos três diferentes grupos. 


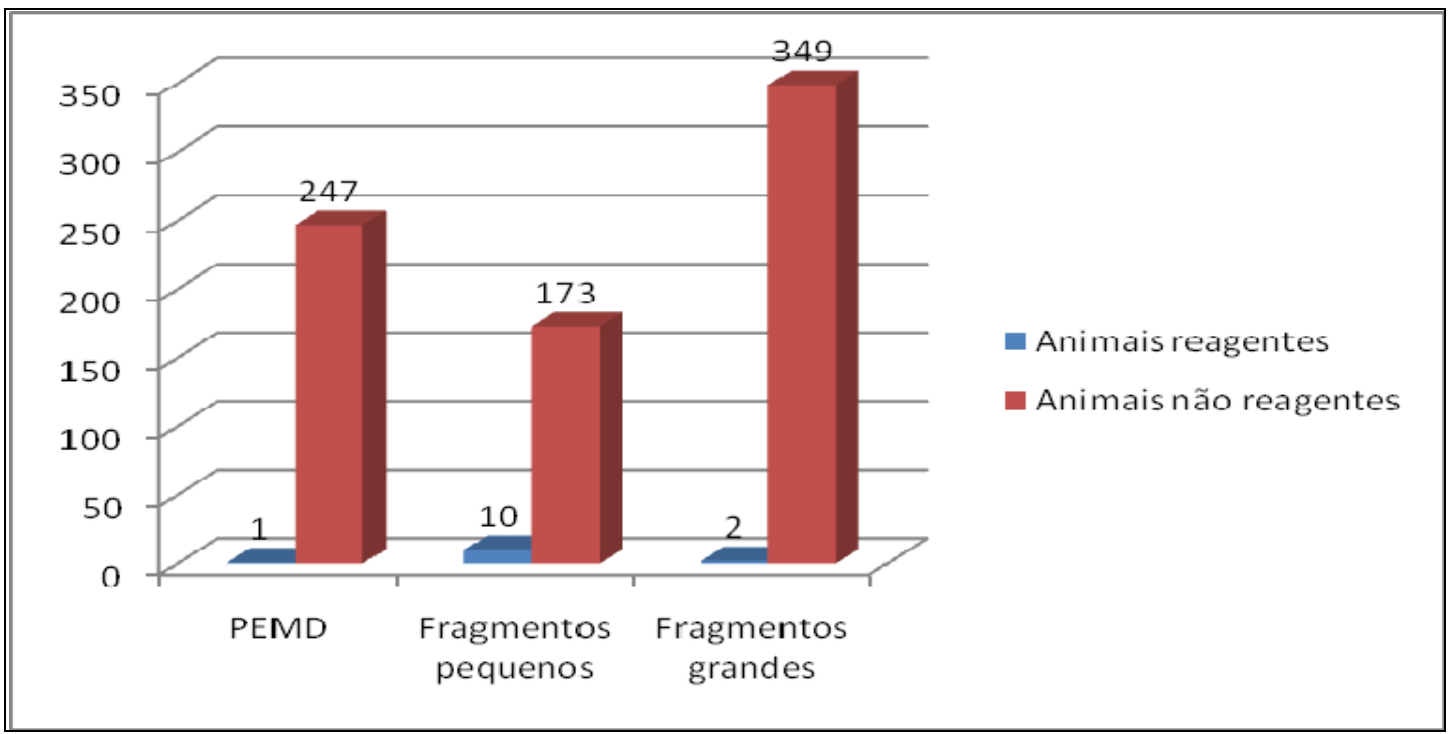

Figura 27 - Bovinos reagentes para brucelose no entorno dos diferentes fragmentos florestais.

Houve diferença significativa no número de animais com sorologia positiva nos diferentes fragmentos $\left(\chi^{2}=0.00\right)$.

Agrupando os bovinos amostrados no entorno dos fragmentos pequenos e grandes, e comparando-se com os bovinos amostrados no entorno do PEMD, não houve diferença significativa $\chi^{2}=0.11$. Na figura 28 abaixo, os bovinos reagentes e não reagentes para brucelose nos três grupos estudados:

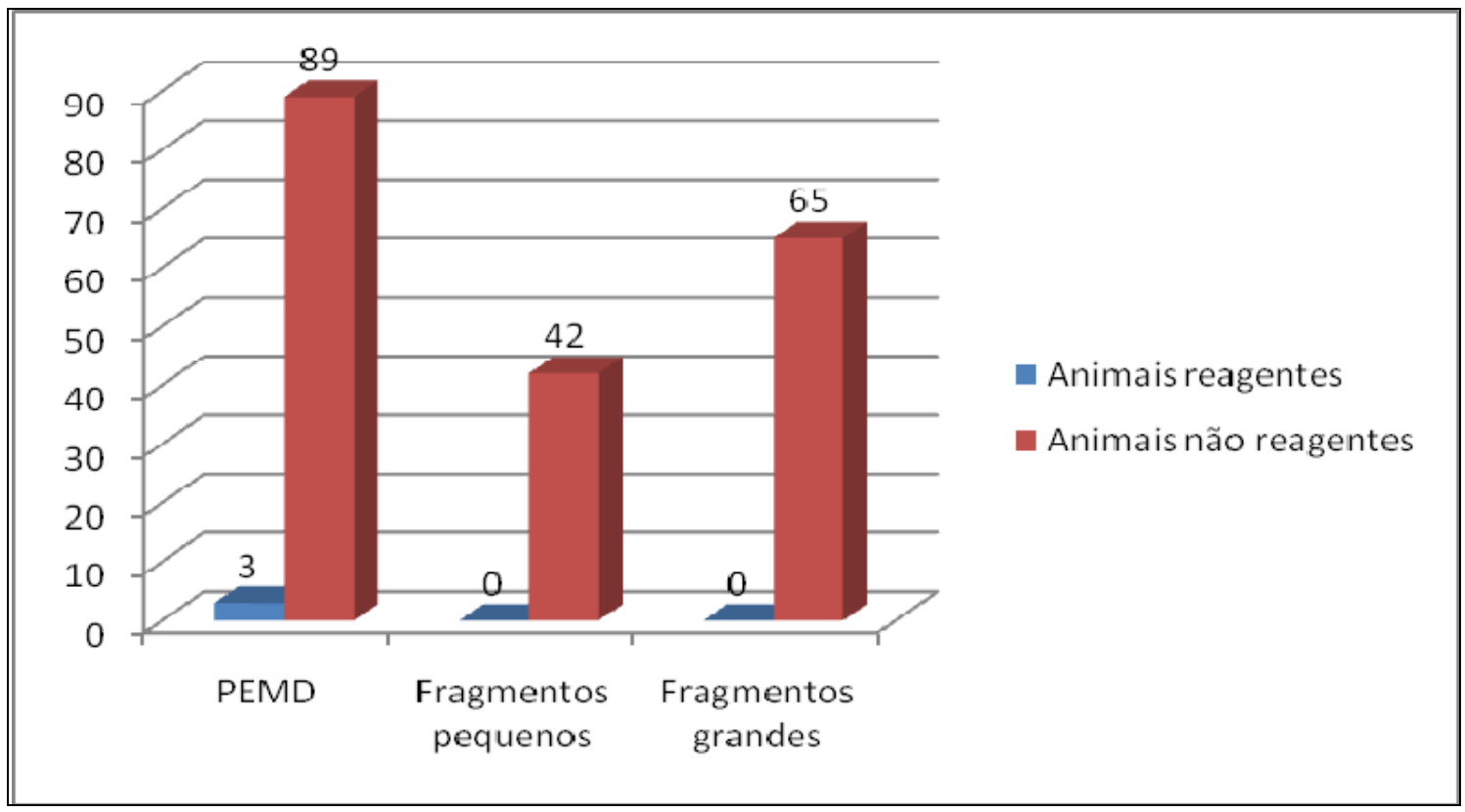

Figura 28 - Cães reagentes para brucelose nos diferentes fragmentos florestais 
Dos 92 cães amostrados no entorno do PEMD, $\mathrm{n}=3$ animais foram reagentes para brucelose, sendo que dois animais pertenciam a mesma propriedade. Nesta propriedade $n=1$ bovino foi positivo sugerindo que os cães possam ter tido contato com a bactéria através do leite desse animal ou restos placentários. Não houve diferença significativa entre os cães reagentes e não reagentes amostrados no entorno dos três diferentes grupos $\chi^{2}=0.32$. Comparando os caninos do entorno do PEMD, com os caninos do entorno dos dois grupos (fragmentos pequenos e grandes) não foi encontrada diferença significativa $\chi^{2}=0.2$.

Não houve nenhum suíno, eqüino e ovino reagente para brucelose entre os animais amostrados.

Em todos os animais amostrados foi feita a tentativa de isolamento através de swab vaginal ou prepucial através de meio de transporte de Stuart. Todas as amostras mostraram-se inconclusivas.

5.8.3 Animal doméstico e silvestre

Comparando-se o número de taiassuídeos reagentes para brucelose amostrados no PEMD e bovinos reagentes no entorno do PEMD, houve diferença significativa $\chi^{2}=0.00$. Na figura 29 abaixo os bovinos e taiassuídeos reagentes e não reagentes para brucelose: 


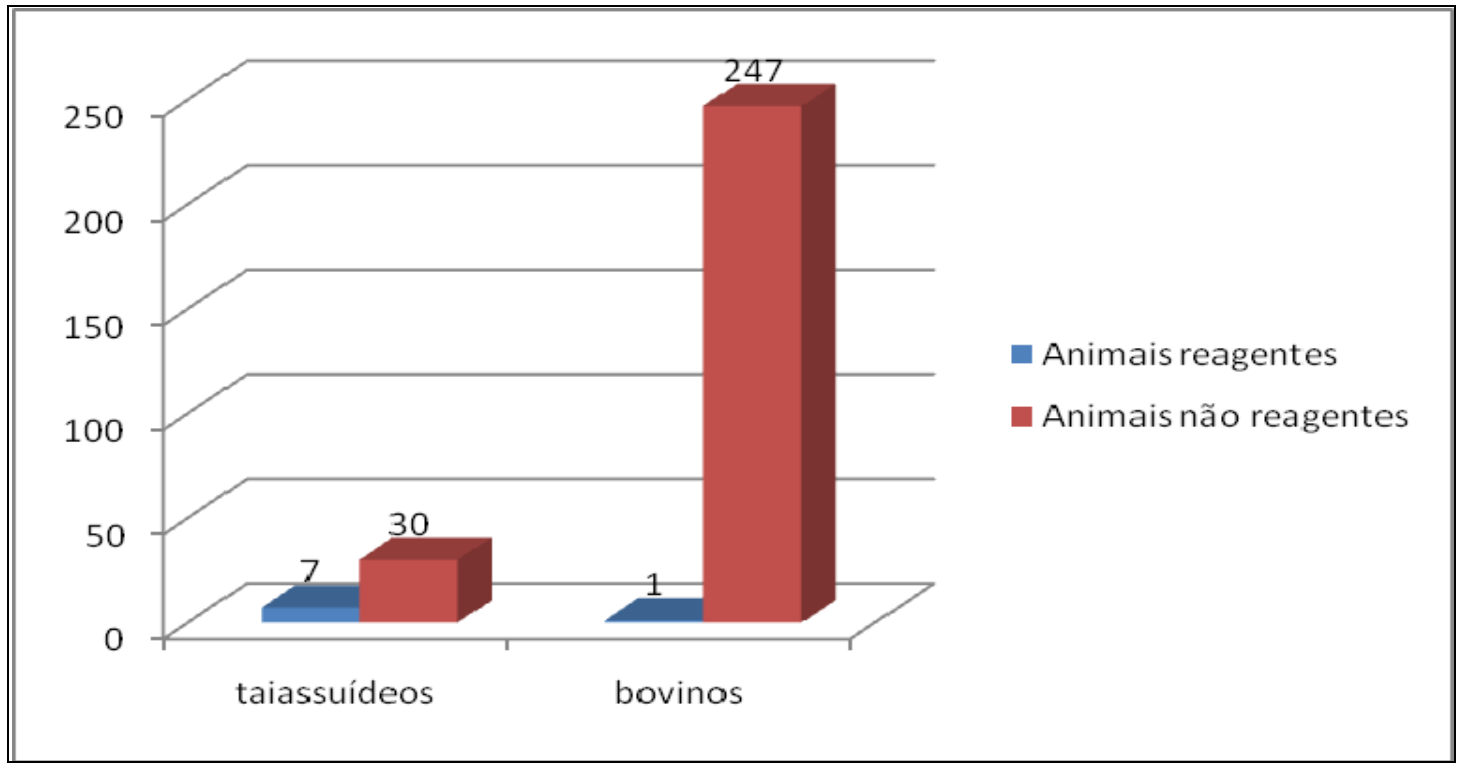

Figura 29 - Bovinos amostrados no entorno de PEMD e taiassuídeos amostrados no PEMD reagentes e não reagentes para brucelose

Comparando-se taiassuídeos amostrados em fragmentos pequenos reagentes para brucelose com o número de bovinos reagentes amostrados para brucelose no entorno dos fragmentos pequenos, não houve diferença significativa $\chi^{2}=0.44$. Também para os taiassuídeos amostrados nos fragmentos grandes e bovinos reagentes amostrados nos entornos dos fragmentos grandes, não foi encontrada diferença significativa $\chi^{2}=0.65$. 


\subsection{IMUNODEFICIÊNCIA FELINA E LEUCEMIA FELINA}

O número de gatos domésticos, que vivem no entorno do PEMD, é de 102 indivíduos $(n=102)$. Foram colhidas amostras de 17 gatos domésticos no entorno do PEMD em locais de maior proximidade das propriedades rurais ao PEMD e maior adensamento de animais e humanos. Os locais de amostragem situam-se na face leste e oeste do PEMD. Na face leste se localiza o bairro Córrego Seco, composto por pequenos sítios e algumas propriedades maiores. Na face oeste está o assentamento de reforma agrária Ribeirão Bonito.

Ao exame clínico os gatos apresentaram-se em sua maioria subnutridos e com infestação de ectoparasitas (pulgas e carrapatos), mas aparentemente não apresentavam sintomatologia de qualquer doença infecto contagiosa. Os felídeos selvagens capturados foram oito onças pintadas (Panthera onca), duas onças pardas (Puma concolor) e quatro jaguatiricas (Felis pardalis) e apenas uma onça pintada macho estava abaixo do peso. Porém na segunda captura se encontrava com peso normal. Os animais domésticos e silvestres testados não foram reagentes para imunodeficiência felina e leucemia felina. No mapa 7 abaixo, os locais de amostragem dos animais domésticos e silvestres deste estudo. 


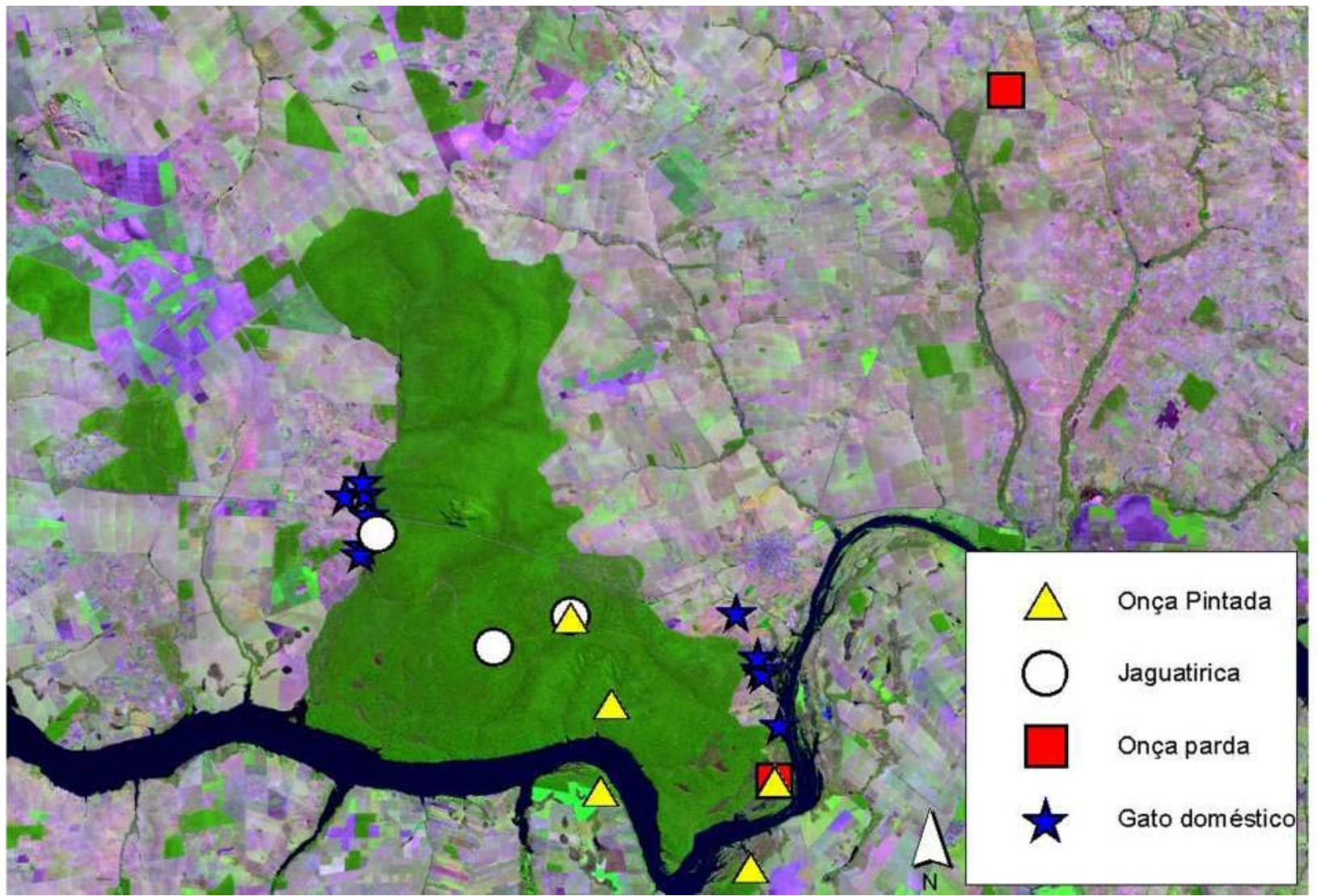

Mapa 7 - Locais de amostragem dos felinos domésticos e silvestres 


\section{DISCUSSÃO}

Nesta seção são discutidos os resultados encontrados neste estudo e a comparação dos achados entre os demais fragmentos estudados.

\subsection{CARACTERÍSTICAS ECOLÓGICAS DOS FELÍDEOS E TAIASSUÍDEOS}

O tamanho do grupo de catetos do PEMD e Ponte Branca e Tucano (grupo fragmentos grandes), aproxima-se da média encontrada em outros fragmentos florestais da Mata Atlântica do interior paulista (8.8 indivíduos / grupo) (KEUROGHLIAN et al., 2004). No fragmento Santa Zélia (fragmento pequeno), onde foram capturados apenas dois indivíduos, não foram encontrados rastros indicando a presença de um grupo estruturado de catetos neste fragmento (8.8 indivíduos / grupo) (KEUROGHLIAN et al., 2004), estimando-se dois indivíduos ou três no fragmento. O fragmento pequeno Ribeirão Bonito, entretanto, se encaixa na média de 8.8 indivíduos / grupo (KEUROGHLIAN et al., 2004). Ambos fragmentos são próximos ao PEMD, porém o fragmento Ribeirão Bonito tem maior possibilidade de trânsito de catetos do PEMD para fragmento devido aos sistemas agroflorestais que se localizam nas propriedades do assentamento, e ficam entre o PEMD e o fragmento Ribeirão Bonito. No fragmento Santa Zélia há uma estrada asfaltada entre o PEMD e o fragmento, podendo ser uma explicação da baixa densidade de catetos mesmo com a proximidade similar destes dois fragmentos com o PEMD. Gonçalves (2007), estudando o padrão genético dos catetos e queixadas do Pontal do Paranapanema demonstra que ambas espécies não tem uma dispersão homogênnea comparada com outras espécies de herbívoros e carnívoros, e preferem se mover em fragmentos com vegetação nativa, confirmando a estrada como uma barreira para a dispersão destas espécies.

Nos fragmentos Água Sumida e Santa Maria, pertencentes ao grupo fragmentos grandes, não foi capturado taiassuídeos nesses dois fragmentos, apesar da intensa campanha de captura. É muito provável que esses fragmentos estejam enfrentando a extinção local de taiassuídeos devido ao gargalo em que se 
encontraram essas duas espécies após o desmatamento intenso da região e algumas décadas de isolamento. As relações de fonte - dreno (DITT, 2002) se aplicam a este resultado de capturas nos fragmentos citados, e se apóia na própria história da região, em que uma área após sofrer intenso desmatamento, os fragmentos de floresta remanescentes funcionam como sumidouro, e o maior fragmento de mata e mais contínuo, no caso o Parque, teria a função de "fonte" (DITT, 2002). Nesta relação, os fragmentos menores tendem a ter uma densidade alta de espécies após o desmatamento, e em seguida ocorre um declínio populacional devido a competição por alimentos, e tamanho de território relacionado à área de uso da espécie e doenças (BARBRAUD et al., 2003; REJMÁNKOVÁ et al., 2006).

O fragmento Santa Mônica, mesmo possuindo um tamanho menor que os fragmentos Santa Maria e Água Sumida, apresenta um grupo de queixadas. A explicação para esse fato pode ser a história de ocupação do entorno dos diferentes fragmentos florestais, e como esse modo de ocupação influencia na viabilidade de algumas espécies. $O$ fragmento Santa Mônica fica dentro de uma fazenda, sendo parte de sua área averbada. Os demais fragmentos grandes Santa Maria e Água Sumida possuem uma densidade de pessoas e uma pressão de caça que pode ter sido responsável pelo desaparecimento local dessas espécies.

No fragmento Santa Mônica, durante o reconhecimento do fragmento florestal e escolha dos locais de captura, foram avistados rastros de catetos. Mas, sendo o fragmento pequeno (584 ha), quando a ceva era instalada, o grupo de queixadas impedia a presença dos catetos nas cevas, pela competição por alimento e território. O fragmento Santa Mônica por seu tamanho, distância do PEMD e isolamento era o local com menos probabilidade de se encontrar queixadas. Em oposição, o fragmento Tucano pela sua proximidade com o PEMD e tamanho teria chance maior de se encontrar queixadas. Porém, a história do fragmento Tucano, Água Sumida e Santa Maria tem algus pontos em comum: alta densidade de pessoas; alta densidade de diversas espécies domésticas; grande pressão de caça no fragmento.

A população de queixadas e catetos no fragmento Santa Mônica pode ser considerada sobrevivente em todo esse processo pós-desmatamento. Nos fragmentos menores e isolados como o Santa Mônica deveriam ser os primeiros a ocorrer o desaparecimento de mamíferos de médio porte (FAHRIG; MERRIAN, 
1993). Entretanto, o modo de ocupação do entorno do fragmento tem um peso muito importante na continuidade de certas espécies silvestres.

Perante esses resultados de captura, é possível concluir que mesmo fragmentos pequenos que teriam a função de sumidouro após um processo de desmatamento intenso, ainda abrigam populações de taiassuídeos. A questão principal é até quando um fragmento de 584 ha terá capacidade de manter uma espécie que necessita de uma área de uso de aproximadamente 1.871 ha (KEUROGHLIAN et al., 2004).

Atualmente o fragmento Tucano e Ponte Branca fazem parte da Estação Ecológica Mico Leão Preto. Porém, o histórico de ocupação do entorno do fragmento Ponte Branca (fragmento grande) e Santa Mônica (fragmento pequeno) é bastante semelhante. Ambas as áreas são circundadas por fazendas com predomínio de gado de corte, onde há uma pressão de caça bem menor que em fragmentos de mata circundados por assentamentos. O fragmento Ribeirão Bonito e Santa Zélia (fragmentos pequenos) são circundados por assentamentos da reforma agrária como o fragmento Tucano. Em fragmentos de floresta de Mata Atlântica com tamanho de 2.000 ha e com intensa pressão de caça, antas, queixadas e veados são rapidamente levados à extinção local. Em locais onde a pressão de caça é moderada, os bandos de queixada têm sua dinâmica alterada e a população de ungulados é reduzida (CULLEN et al., 2000).

Comunidades rurais vizinhas a fragmentos de floresta, produz perda gradual da biodiversidade nos fragmentos, principalmente por: (a) caça ilegal, (b) erosão das bordas da mata por: fogo, pastejo do gado, colonização, dessecação pelo vento, invasão de sementes de gramíneas agressivas e pesticidas. Esse processo modifica a estrutura da floresta, afetando processos ecológicos e causando a perda de muitas espécies animais e de plantas devido a uma "defaunação" (TERBORGH, 1988; BROWN; HESKE, 1990; DIRZO; MIRANDA, 1990) e efeitos de borda (TERBORGH, 1974; SAUNDERS et al., 1991; LAURANCE, 1991; MURCIA, 1995; DIDHAM et al.,1996; KAPOS et al., 1997).

O fragmento Tucano se enquadra nesta situação, tendo no seu entorno um dos primeiros assentamentos da reforma agrária da região, com intensa pressão de caça. Em estudos ecológicos no fragmento Tucano no ano de 2000 realizados por Cullen (2000, p. 56) revelaram que a população de ungulados desta floresta não atinge 50 indivíduos o que evitaria a depleção genética na população. Com este 
resultado, ressalta-se a importância do histórico de ocupação do entorno como uma variável importante na presença e ausência de algumas espécies animais.

Em entrevistas com proprietários rurais dos fragmentos florestais do Pontal do Paranapanema, com o objetivo de obter pontuações em comportamentos de conservação, os proprietários com menor pontuação foram o casal que possuía o fragmento Tucano. Este proprietário já foi multado 14 vezes e ficou preso durante um mês por agressão contra o meio ambiente (DITT, 2002). Portanto o fragmento Tucano sofreu por diversas vezes a agressão de um proprietário que via na floresta um empecilho na sua expansão e produtividade (comunicação pessoal) e também de um assentamento da reforma agrária exercendo enorme pressão de caça. Cullen et al., (2001) caracteriza o fragmento Tucano como um dos mais intensamente caçados dentre os cinco fragmentos de Mata Atlântica pesquisados (CULLEN et al., 2001).

O PEMD que por ser uma área protegida, e com fiscalização própria tem uma pressão de caça menor (CULLEN et al., 2001). Em fazendas, geralmente a caça não é admitida por facilitar o roubo de gado, motivando os proprietários rurais a terem um controle severo nesse assunto, essa atitude ocorre nas fazendas Santa Monica e Ponte Branca. O modo de ocupação do entorno do fragmento, densidade de pessoas e animais domésticos, atitude e comportamento do proprietário, são fatores determinantes para a viabilidade de algumas espécies na paisagem fragmentada.

Durante a elaboração deste estudo, foram encontradas oito onças pintadas no total. Em trabalho envolvendo armadilhamento fotográfico para obtenção de quantidade de onças no PEMD, foi constatado que o número mínimo da população no PEMD é de 6 indivíduos, ou de 2,22 indívíduos por $\mathrm{km}^{2}$ (CULLEN et al., 2005). Estes dados demonstram a validade da amostragem deste estudo como bastante alta para caracterizar epidemiologicamente a população de onças pintadas do PEMD. Ainda em trabalho envolvendo armadilhamento fotográfico no PEMD, constatou-se que a capacidade populacional de jaguatiricas no PEMD é de 95-125 indivíduos residentes e densidade 0,27-0,36 ind./Km² (JACOB, 2002).

Os felídeos do Pontal do Paranapanema enfrentam a falta de habitat para a dispersão das novas gerações. A fragmentação da região, e o alto requerimento de área de uso da espécie coloca esses animais na berlinda, deixando-os muito próximos a animais domésticos e seus patógenos. 


\subsection{ECTOPARASITAS}

A espécie de carrapato mais freqüente nos queixadas e catetos capturados foi o A. naponense seguido do Amblyomma cajennense. Estas espécies ocorreram em todos fragmentos estudados e em ambas espécies de taiassuídeos.

$O$ A. naponense foi encontrado em porcos criados em fazenda com acesso irrestrito ao pasto e a mata Equatorial Amazônica nativa adjacente (LABRUNA et al., 2002). A presença de Amblyomma cajennense foi descrita em capivaras (Hydrochaeris hydrochaeris) e queixada (Tayassu pecari), na região do Pantanal (ITO et al., 1998).

O fato do Amblyomma cajennense não apresentar especificidade em relação aos hospedeiros pode propiciar maiores riscos de disseminação de patógenos transmitidos por estes artrópodes com o envolvimento humano (MARTINS et al., 2004), pois os estágios imaturos mostram baixo nível de especificidade especialmente os estágios larvais, indicando a existência de hospedeiros secundários que provavelmente servem como dispersores na natureza (LISBÔA LOPES et al., 1998).

Em queixadas e catetos amostrados nos fragmentos pequenos não foram encontrados Amblyomma coelebs. Esse resultado pode demonstrar uma especificidade maior do carrapato e a dificuldade de amostrá-lo em ambiente com menor diversidade de hospedeiros específicos. Os adultos da espécie Amblyomma coelebs são comuns em antas, mas também foram encontrados em humanos e cavalos (BELDOMÉNICO et al., 2003; NAVA et al., 2004). A lista de carrapatos encontrados nos catetos e queixadas encontram-se respectivamente nos (Apêndices C e D).

Somente nos catetos e queixadas amostrados em fragmentos grandes, foram coletados carrapatos da espécie Amblyomma brasiliense. Na Argentina, existem registros de $A$. brasiliense parasitando humanos (GUGLIELMONE; VIÑABAL, 1994), e pesquisadores na Mata Atlântica brasileira foram mordidos por Amblyomma brasiliense (SZABÓ et al., 2006).

Verificou-se que os fragmentos grandes apresentam maior índice de riqueza $(\mathrm{R})$ e diversidade $\left(\mathrm{H}^{\prime}\right)$ em relação aos ectoparasitas coletados nos queixadas amostrados, como também um maior "eveness" (E), o que significa que nestes locais 
as populações são mais uniformes relativamente ao número de indivíduos por espécie (NETO et al., 1999). Estes dados devem ser analisados cautelosamente, pois apesar desses resultados obtidos demonstrarem que os fragmentos grandes têm maiores índices de diversidade de carrapatos que o PEMD e maior número de espécies coletadas, isso não significa que os fragmentos grandes tenham uma maior biodiversidade geral. Muitas doenças que residem em animais reservatórios são transmitidas por vetores artrópodes através da picada. Muitos desses vetores se alimentam de uma grande variedade de espécies hospedeiras que diferem muito entre si quanto à competência reservatória para determinado patógeno, o que siginifica a probabilidade de conseguir transmitir o patógeno do hospedeiro ao vetor.

O "efeito diluição" é alcançado, quando em um determinado local, há a presença de hospedeiros vertebrados com baixa capacidade de infectar os vetores, diluindo o efeito dos reservatórios altamente competentes (KENNETH; SCHMIDT, 2001), e com a remoção de floresta e fragmentação do habitat teremos a redução ou perda da biodiversidade (WILSON, 1992; HOBBS, 1994), tendo um "efeito diluição" reduzido ou inexistente.

Os índices de diversidade mais baixos dos três grupos foram os provenientes da análise dos carrapatos coletados do grupo fragmentos pequenos.

Os queixadas capturados no grupo fragmentos pequenos foram provenientes da floresta Santa Mônica apresentando apenas as espécies $A$. cajennense e naponense. Sendo que todos os queixadas amostrados neste fragmento foram coletadas fêmeas e machos adultos de $A$. cajennense, e com maior freqüência comparando-se com todos os demais fragmentos do estudo, incluindo o PEMD.

O $A$. cajennense é uma espécie importante em termos de saúde pública pois parasita animais domésticos e atua como vetor da Rickettsia ricketsii (TRAVASSOS; VALEJO-FREIRE, 1944). O A. cajennense é um parasita com ciclo de três hospedeiros ocorrendo na maioria das vezes em eqüinos, mas alcançando um vasto número de espécies hospedeiras (LINARDI et al., 1991). É importante determinar os hospedeiros secundários na manutenção do seu ciclo biológico, como os queixadas. A ocorrência de Boophilus microplus em onças pintadas está relacionada ao hábito de atravessar áreas de pasto, e predar gado. Entre os resultados dos índices de diversidade dos carrapatos coletados em catetos, o maior índice de riqueza (R1) e "eveness" (E) ocorreu no PEMD. O índice de diversidade $\left(H^{\prime}\right)$ maior ocorreu no grupo fragmentos grandes. Os carrapatos encontrados nos catetos amostrados no 
PEMD foram Amblyomma cajenense, naponense e sp. Foram amostrados mais catetos nos fragmentos grandes $n=21$ do que no PEMD, $n=8$ e fragmentos pequenos $\mathrm{n}=9$.

Esse desequilíbrio amostral pode ter afetado o resultado dos índices, principalmete o "eveness" que mostra a igualdade de distribuição das espécies coletadas. Os carrapatos coletados dos catetos provenientes dos fragmentos grandes foram: Amblyomma sp. , A. naponense, A. brasiliensis, A. coelebs e A. cajennense. Nos fragmentos pequenos foram coletados os seguintes carrapatos dos catetos amostrados: Amblyomma sp. , A. naponense, e A. cajennense.

Os taiassuídeos amostrados no PEMD apresentaram menores freqüências de carrapato por captura, esse resultado pode indicar o "efeito diluição" no PEMD, uma área contínua, com maior diversidade de hospedeiros. O fragmento pequeno Santa Mônica, seguido do fragmento pequeno Ribeirão Bonito, demonstraram as maiores freqüências de carrapatos em taiassuídeos por captura.

O índice de similaridade Jaccard entre os carrapatos coletados de catetos nos diferentes grupos (PEMD, fragmentos pequenos e fragmentos grandes) mostra maior similaridade entre os carrapatos coletados no PEMD e fragmentos pequenos (66.6\%). Este Índice é baseado na relação entre o número de espécies comuns às duas áreas e o número de espécies coletadas. O PEMD e o grupo fragmentos grandes, e fragmentos grandes e fragmentos pequenos apresentaram $40 \%$ de similaridade. $O$ índice de similaridade dos carrapatos coletados dos queixadas do PEMD e fragmentos grandes foi (80\%), pois foram coletadas 4 espécies em comum, sendo menor a similaridade com fragmentos pequenos $(50 \%)$, e fragmentos pequenos e fragmentos grandes apresentaram similaridade de (40\%).

O fato de terem sido encontrados poucos carrapatos nos catetos capturados, pode ser um indicativo para o índice de similaridade do PEMD ser maior com o grupo fragmentos pequenos.

É necessário conhecer a importância dos taiassuídeos como hospedeiros secundários de carrapatos do gênero Amblyomma e a interação epidemiológica em cada fragmento de estudo. 


\subsection{ENDOPARASITAS}

Os endoparasitas coletados das fezes de catetos do PEMD não puderam ser calculados por ser um número muito reduzido. O gênero encontrado foi Ascarídeolike. Fezes de cateto coletadas na Serra da Capivara, foram identificados ovos de quatro espécie/morfotipos de nematódeos Strongyloidea 1, Strongyloidea 2, Ancylostomatidae 5, Ascaridiae 2 e ovos de uma espécie/morfotipo não identificada (BRANDÃO, 2007). Em catetos sacrificados, provenientes do Pantanal de Paiaguás, Mato grosso do Sul foram encontrados Physocephalus sexalatus, Ascarops strongylina, Parabronema pecarie, Texicospirura turki, Trichostrongylus axei, T. colubriformis, Spiculopteragia tayassui, Cooperia spatulata, C. punctata, Parostertagia heterospiculum, Strongyloides ransomi, Monodontus aguiari, $M$. semicircularis, Macracanthorhynchus hirudinaceus, Oesophagostomum dentatum, Eucyathostomum dentatum, Stichorchis giganteus, Metastrongylus salmi e Dirofilaria acutiúscula (NASCIMENTO et al., 2005). Os índices de diversidade (H') e "eveness" (E) foram mais elevados nos endoparasitas coletados de catetos amostrados nos fragmentos grandes. Nestes fragmentos foram encontrados Strongyloidea-like, Strongyloides-like, Ascarídeo-like, Giardia sp. , Ascarídeo Ascaris suum-like e nos fragmentos pequenos Strongyloidea-like, Strongyloides-like, Ascarídeo-like. Os Estrongilídeos, Metastrongilídeos, Ascaris suum e Trichuris suis tem sido identificados, com alta freqüência, em estudos com taiassuídeos silvestres.

Os nematódeos listados por Vicente et al. (1997) em catetos são: Eucyathostomum dentatum, Gongylonema baylisi, Molineus semicircularis, Nematodirus molini e Oesophagostomum dentatum. Neto e Thatcher (1986) acrescentam a esta lista Parabronema pecariae.

Os endoparasitas coletados das fezes de queixadas do PEMD apresentaram os maiores índices de diversidade ( $\left.\mathrm{H}^{\prime}\right)$ e "eveness" máximo. As fezes de queixadas do PEMD apresentaram os seguintes ovos de endoparasitas: Strongyloidea-like e Ascarídeo-like, em apenas dois indivíduos amostrados. Nas amostras provenientes dos fragmentos grandes os índices de diversidade $\left(\mathrm{H}^{\prime}\right)$ e "eveness" foram aproximados ao PEMD e riqueza ( $R$ ) foi superior devido a um maior número de queixadas parasitados. Os endoparasitas encontrados foram: Strongyloidea-like e Giardia sp. 
Nos fragmentos pequenos, os parasitas encontrados foram: Strongyloidea-like e Ascarídeo-like. Em queixadas abatidos no Mato Grosso do Sul, foram identificados Physocephalus sexalatus, Ascarops strongylina, Trichostrongylus axei, Texicospirura turki e Spiculopteragia tayassui; no intestino delgado, Parostertagia heterospiculum, Monodontus semicircularis, M. aguiari e Macracanthorhynchus hirudinaceus; no intestino grosso, Eucyathostomum dentatum, Oesophagostomum dentatum e Stichorchis giganteus; e, ainda, Dirofilaria acutiuscula e Metastrongylus salmi (NASCIMENTO et al.,2005).

Analisando os resultados dos índices de similaridade dos endoparasitas identificados nas fezes de catetos e queixadas, houve maior similaridade entre os endoparasitas encontrados nas fezes de taiassuideos dos fragmentos grandes e fragmentos pequenos. A similaridade de endoparasitas coletados em queixadas e catetos desses dois grupos de fragmentos (fragmentos grandes e fragmentos pequenos) pode ser um indicativo do efeito da fragmentação na dinâmica de endoparasitas. Lymbery (2005) comenta que os parasitologistas sempre estudaram a parasitologia por uma visão reducionista, e que apesar de devido a esta visão terem alcançado importantes avanços no tratamento e controle de doenças parasitárias, negligenciaram a importância que os parasitos têm como modelo para se estudar questões ecológicas e evolutivas, podendo ser bons indicadores de saúde de ecossistemas. Para isso são necessários estudos que abordem a biologia parasitária na população e, em nível de comunidade.

Pesquisas com patógenos em populações silvestres poderão elucidar questões sobre suas origens, a determinação de doenças emergentes e fatores que influenciam a manutenção destes patógenos em seus reservatórios. Desta forma, possibilitar o conhecimento das relações inter e intraespecíficas de parasitas e hospedeiros em um ecossistema. O conhecimento da diversidade microbiológica de um ecossistema, pode nos ajudar a entender a influência de comunidades microbiológicas na integridade de ecossistemas (OGUNSEITAN, 2005). 


\subsection{CARACTERÍSTICAS DE MANEJO DOS ANIMAIS DOMÉSTICOS NO ENTORNO DOS DIFERENTES GRUPOS DE FRAGMENTOS}

Divididos os animais domésticos em três grandes grupos: fragmentos grandes, pequenos e PEMD, para comparação do manejo no entorno das florestas conclui-se que o tipo de manejo nos três diferentes locais não difere muito. A razão pela qual isso ocorre, é que os três grupos possuem fazendas e assentamentos no seu entorno, sendo que apenas no entorno do PEMD há sítios, porém estes com densidade de animais domésticos, tamanho da propriedade e modo de produção semelhantes aos assentamentos. Os fragmentos de mata pequeno Santa Mônica e o fragmento de mata grande Ponte Branca são os únicos fragmentos circundados por fazendas, sem assentamentos no entorno.

Os cães que vivem no entorno dos fragmentos, regularmente entram nas áreas de mata para caçar, demarcar território, ou acompanhar o dono nas caçadas. A presença de cães dentro e no entorno de áreas protegidas, e o risco que isso possa representar para as espécies ameaçadas de carnívoros, dado o potencial de transmissão de doenças tem progressivamente recebido atenção das comunidades científicas de conservação (DEEM; EMMONS, 2005). Trabalhos bem coordenados de vacinação na América do Norte e Europa fizeram a ocorrência de transmissão de doenças de carnívoros domésticos para animais silvestres raras (RUPPRECHT et al., 1995; CHANG et al., 2002).

A falta de um manejo adequado dos animais domésticos, incluindo esquema de vacinação é altamente preocupante para a sanidade das pessoas e animais silvestres que coabitam essa região.

A distribuição dos animais domésticos na paisagem fragmentada do Pontal do Paranapanema, sua proximidade com o PEMD e demais fragmentos, a falta de controle populacional, nos levam a concluir que os animais silvestres dessa região estão suscetíveis as doenças transmitidas por animais domésticos do entorno desses fragmentos.

Nos assentamentos e sítios, como há maior densidade de animais domésticos, o risco do surgimento de doenças infectocontagiosas é maior do que em grandes propriedades, onde geralmente os cães e gatos estão próximos a sede e distantes da floresta. A possibilidade de transmissão de patógenos de uma 
população grande de animais domésticos para uma população menos adensada de animais silvestres pode resultar em uma epidemia de determinada doença em populações de carnívoros ameaçada (LAURENSON et al., 1998).

\subsection{CINOMOSE}

Os resultados encontrados indicam que os cães da região do Pontal do Paranapanema foram expostos ao vírus da cinomose, e que há um grande potencial do vírus da cinomose dos cães entrarem em contato com a população de carnívoros selvagens na região do Pontal do Paranapanema. O PEMD não permite a entrada de animais domésticos na UC. Entretanto, caninos domésticos são frequentemente avistados em estradas centrais do PEMD, inclusive áreas consideradas pelo Plano de manejo da unidade como áreas intangíveis, e relatos de predação de caninos por onças ocorrem ao menos duas vezes ao ano. Em populações maiores de animais domésticos aumentam as possibilidades de grandes populações transmitirem seus patógenos para populações menores de carnívoros silvestres de vida livre (GASCOYNE et al., 1993; ROELKE-PARKER et al., 1996; LAURENSON et al., 1998).

Os cães apresentando títulos para cinomose nos mostram que a sua presença dentro de áreas protegidas, representa uma ameaça à saúde da população de carnívoros silvestres por abrigarem doenças infecciosas susceptíveis a estas espécies (FIORELLO et al., 2004). Durante epizootia em canídeos da África, os cães foram identificados como sendo a origem mais provável do agente (CLEAVELAND et al., 2003). Em trabalho recente na população das onças do Parque Estadual de Ivinhema, 21\% dos felídeos silvestres amostrados apresentaram titulação para cinomose, e 100\% dos cães domésticos amostrados foram reagentes (NAVA et al., 2007).

No Parque Estadual de Ivinhema o relato de predação de cães por onça pintada e as incursões destes dentro da Unidade são muito mais frequentes que no PEMD. A comparação de resultados dessas duas áreas pode indicar que um maior contato entre as os canídeos domésticos e os felídeos selvagens pode propiciar a troca de patógenos (NAVA et al., 2007). 
Para prevenir futuros declínios populacionais é necessário identificar e quantificar os riscos antes que a doença possa causar um impacto na população de felídeos selvagens (CLEAVELAND et al., 2003). No passado, cães domésticos portadores de cinomose causaram declínio populacional em várias espécies ameaçadas como o lobo selvagem africano (Lycaon pictus) entre outros (GASCOYNE et al., 1993).

O método diagnóstico para cinomose em felídeos selvagens e cães domésticos foi a soroneutralização lenta. Esse teste diagnóstico já foi utilizado em animais silvestres, em uma epizootia em guaxinim (Procyon lotor) e em raposa cinza (Urocyon cinereoargentus) nos Estados Unidos e os animais reagentes, com titulação de até 1:20 apresentaram lesões microscópicas relacionadas a cinomose (HOFF et al., 1974). O uso de RT- PCR para diagnóstico da cinomose é indicado quando se quer caracterizar a cepa de cinomose encontrada (HAAS et al.,1996; STANTON et al., 2004) e seria a ferramenta indicada para uma nova amostragem desses animais, se no resultado da soroneutralização houvesse felídeos silvestres e taiassuídeos reagentes. Entretanto, nas epizootias de cinomose em animais silvestres, os sequenciamentos indicam que não há uma linhagem adaptada de cinomose para felídeos silvestres, e que a causa inicial da epizootia é devida a transmissão interespécies de cinomose de carnívoros domésticos e ferais que vivem em proximidade aos felídeos silvestres (HARDER et al., 1996). As cepas de cinomose são relacionadas geograficamente, como no Serengeti entre as hienas (Crocuta crocuta) e os leões (Panthera leo), a cepa de cinomose encontrada nas duas populações simpátricas eram homólogas (HAAS et al., 1996).

A percepção do aumento da mortalidade em carnívoros da fauna silvestre brasileira é dificultada em nosso país pela característica de nossos biomas (JORGE, 2008). Essa característica é aplicada ao local de estudo, Mata Atlântica do interior, na qual a visualização de um felídeo silvestre é rara. 


\subsection{LEPTOSPIROSE}

Os resultados obtidos neste estudo demonstram que os taiassuídeos e onças pintadas do Pontal do Paranapanema foram expostos a Leptospira spp. , bem como os animais domésticos que vivem no entorno das florestas desta região.

Houve maior frequência de queixadas reagentes para leptospirose no PEMD comparado aos fragmentos, e foi estatisticamente significativo. Esse fato pode ser explicado pela história do entorno do PEMD e do modo de ocupação do entorno dos fragmentos. O entorno do PEMD tem mais tempo de ocupação e um adensamento maior de animais domésticos do que o dos fragmentos Ponte Branca e Santa Mônica. Esses fragmentos são circundados por grandes latifúndios, enquanto que o PEMD tem como vizinhos desde assentamentos da reforma agrária, sítios e uma porcentagem menor de latifúndios. Esse tipo de contato pode ser um fator a proporcionar um maior tempo de contato entre os animais domésticos circunvizinhos e animais silvestres do PEMD, resultando em um maior número de animais reagentes.

A história de ocupação da região, e seu desmatamento intenso durante 4 décadas, contribuíram com esse quadro epidemiológico. A população de animais silvestres do Pontal está ainda passando por um processo de adaptação na nova paisagem que surgiu nestes 40 anos.

O isolamento é relativamente recente entre os fragmentos e a dinâmica de algumas espécies hospedeiras e reservatórios de algumas doenças está passando também por um processo de adaptação. Com a reforma agrária, pastos vazios que circundavam alguns fragmentos e parte do PEMD, agora estão altamente adensados com animais domésticos e pessoas, muito próximos à mata e aos animais silvestres (SCHLOEGEL et al., 2005).

Os queixadas capturados nos fragmentos eram provenientes da mata da fazenda Santa Mônica (fragmento pequeno) e da Estação Ecológica Mico Leão Preto (fragmento grande), na porção correspondente ao fragmento Ponte Branca. $O$ modo de ocupação do entorno dessas duas matas é bastante semelhante, sendo as matas circundadas por fazendas, e com baixa densidade pessoas e animais domésticos. Esse modo de ocupação proporcionou 2 fatores: a permanência de 
queixadas nestes fragmentos, e uma menor prevalência de queixadas reagentes para leptospirose.

Uma explicação para a permanência de queixadas em um fragmento pequeno como a mata Santa Mônica (400 ha), é uma menor pressão de caça do entorno, visto que o assentamento Tucano, Água Sumida e Santa Maria (2000 ha) não possuem queixadas, pois apresentam um histórico de ocupação totalmente diferente da Santa Mônica e Ponte Branca, possuindo um adensamento muito maior de famílias e alta pressão de caça (CULLEN et al., 2000).

Um maior adensamento humano e animal é encontrado em pequenas propriedades. Nestas, criam-se diversas espécies animais, e em condições mínimas de higiene. No entorno do PEMD, na face oeste onde se localiza o assentamento Ribeirão Bonito, os animais silvestres e domésticos compartilharam o mesmo curso de água durante muitos anos, até que no ano de 2006 a polícia ambiental restringiu essa área. Esse contato por muito tempo pode ter propiciado a exposição a Leptospira spp. em ambas populações (silvestres e domésticas).

Os catetos amostrados no PEMD não foram regentes para leptospirose. $O$ número de catetos reagentes para leptospirose nos fragmentos é baixo, mas pode nos indicar um padrão de sorotipos por localidade. Aumentando o número amostral de catetos no PEMD, poderemos verificar se a fragmentação pode estar alterando o padrão de sorotipos de leptospirose em cada floresta, devido a dinâmica de hospedeiro e reservatório estar modificada nos diferentes fragmentos. Os catetos comparados aos queixadas foram menos prevalentes para leptospirose. Esse resultado pode estar relacionado a biologia da espécie, sendo que os queixadas andam em maiores grupos, e exploram mais o entorno do que os catetos, proporcionando um maior contato com outras espécies.

Os catetos reagentes dos fragmentos pequenos apresentaram o sorotipo mais provável pyrogenes. O sorotipo pyrogenes já foi isolado do silvestre Nectomys squamipes no Brasil com resultados sorológicos positivos em roedores, bovinos e humanos na região Norte do Brasil (SANTA ROSA et al.,1980; FAVERO et al., 2001) e cães errantes no sul do país (BLAZIUS et al., 2005). Apenas $n=1$ queixada amostrado em fragmento pequeno foi reagente e apresentou como sorovar mais provável o sorotipo panama.O entorno do fragmento pequeno Santa Mônica, onde os queixadas foram amostrados, é uma fazenda extensiva de gado bovino, na qual nenhum dos animais domésticos amostrados (suínos, bovinos, eqüinos e ovinos) 
apresentou o sorovar panama. Uma amostragem maior de indivíduos reagentes poderia nos indicar um padrão de sorotipo em queixadas desse fragmento. Os queixadas capturados no PEMD apresentaram pomona como sorovar mais provável. O sorovar pomona é frequentemente associado a suínos (FAINE, 1994). Neste estudo, encontramos anticorpos para sorovar pomona em queixadas do PEMD e em uma onça pintada macho capturada no PEMD. Como queixadas são uma das presas deste felídeo selvagem, podemos considerar que o ciclo da leptospirose em vida livre nessa região pode estar ligada a biologia dessas espécies e sua dinâmica ecológica. O sorovar pomona já foi encontrado em onças pintadas de cativeiro no estado de São Paulo (GUERRA-NETO, 2006), e LARSSON (1981) e DICKESON et al. (1993) estudando a leptospirose em grandes grupos de gatos domésticos, relataram uma maior freqüência do sorovar pomona nestes animais.

Nos fragmentos grandes, o sorovar mais provável encontrado em queixadas foi Icterohaemorrhagiae IV e em catetos o sorovar mais provável foi patoc. O sorovar patoc também foi encontrado em javalis de cativeiro no estado de São Paulo (MARCHIORI et al., 2002).

Dos animais domésticos amostrados no entorno dos diferentes grupos de floresta (PEMD, fragmentos grandes e fragmentos pequenos), não houve diferença significativa na quantidade de animais reagentes e não reagentes por espécie entre os três diferentes grupos, com exceção dos caninos. Os caninos amostrados no entorno dos fragmentos pequenos foram proporcionalmente mais reagentes para leptospirose do que os caninos amostrados no PEMD e fragmentos grandes respectivamente. Nos fragmentos pequenos, o sorovar mais provável entre os caninos foi o hardjobovis. Sendo o sorovar hardjobovis, um sorovar com maior predileção para a espécie bovina, podemos associar proximidade dos cães com os bovinos, e o hábito dos cães acompanharem os peões no pasto no manejo do gado e durante ordenha.

No entorno dos pequenos fragmentos amostrados a predominância é de pequenas propriedades, na forma de assentamentos rurais da reforma agrária com adensamento de animais domésticos. A única exceção é o entorno do fragmento pequeno Santa Mônica, que é cercado por uma fazenda de criação de gado de corte extensiva, e onde não foi encontrado nenhum canino reagente para leptospirose. Mais uma vez, o modo de ocupação do entorno do fragmento pode condicionar a 
uma maior prevalência de leptospirose devido ao adensamento e tipo de manejo dos animais domésticos.

Os bovinos tiveram a maior proporção de animais reagentes para leptospirose entre os animais domésticos $(41,2 \%)$, seguido dos eqüinos (33,5\%). Os eqüinos por serem animais usados em trabalho, e como animais de locomoção tem maior chance de contato com a bactéria. Já os bovinos, a epidemiologia da leptospirose deve estar relacionada a manutenção da mesma dentro dos rebanhos da região, devido ao sorovar mais provável nos três grupos de estudo ( fragmentos grandes , pequenos e PEMD) ser o sorovar hardjo. No entorno dos fragmentos pequenos o sorovar mais provável juntamente com o hardjo foi shermani, e nos fragmentos grandes foi wolfii. No PEMD o sorovar mais provável foi hardjo.

Os suínos do entorno do PEMD e fragmentos pequenos apresentaram 0 mesmo sorovar provável batislava e os suínos do entorno dos fragmentos grandes o sorovar mais provável foi copenhageni. Esse resultado pode estar ligado ao comércio informal de suínos da região, onde os fragmentos pequenos ficam próximos as propriedades do PEMD e a venda e troca de animais é constante entre os proprietários do entorno do PEMD e entorno do fragmento Ribeirão Bonito e Santa Zélia (fragmentos pequenos), com exceção do fragmento pequeno Santa Mônica que é distante do PEMD e os suínos amostrados não foram reagentes.

As tentativas de isolamento para Leptospira spp. foram realizadas em todos animais domésticos reagentes, e em todos animais silvestres amostrados e foram inconclusivas. Nas propriedades onde foram amostrados os animais domésticos foram capturados ratos sinantrópicos (Ratus rattus) $(n=100)$ e nenhum dos animais foi reagente para leptospirose, indicando que na região de estudo, a importância epidemiológica do rato para leptospirose como reservatório deve ser reconsiderada. Houve diferença estatisticamente significativa entre os animais domésticos reagentes do entorno dos fragmentos grandes e taiassuídeos amostrados em grandes fragmentos. Os sorovares mais prováveis em comum que os taiassuídeos amostrados em fragmentos grandes e animais domésticos amostrados no entorno desses fragmentos apresentaram foi patoc e icterohaemorrhagiae IV. Estes encontrados em eqüinos. Esses sorovares em comum podem nos mostrar uma proximidade destas espécies, tanto pela biologia dos taiassuídeos de explorarem o entorno, quanto da função do eqüino na propriedade de trabalho, sendo o animal doméstico que se locomove mais que as outras espécies domésticas da 
propriedade. No entorno dos grandes fragmentos do estudo, em especial o fragmento Tucano, Água Sumida e Santa Maria, houve modificações no uso da terra e ocupação do entorno nos últimos dez anos. Mudanças antropogênicas no uso da terra podem produzir condições que facilitem a expansão geográfica de patógenos via aumento de sua área de extensão, ou reemergencia de hospedeiros, aumentando a prevalência de hospedeiros e reservatórios suscetíveis, e a adaptação do patógeno (WILCOX; GLUBER, 2005).

Comparando taiassuídeos reagentes e não reagentes capturados em fragmentos grandes e pequenos e animais domésticos nos seus entornos, houve diferença estatisticamente significativa entre os dois grupos, mesmo assim, os taiassuídeos amostrados nos fragmentos pequenos não apresentaram nenhum sorovar em comum com os animais domésticos amostrados nos seus entornos.

A ocorrência de reação cruzada entre os sorovares encontrados neste estudo não deve ser descartada. Esses resultados indicam que possivelmente as variantes encontradas estão presentes na região.

A ocorrência de eqüinos, bovinos, suínos, ovinos, caninos, taiassuídeos e onça pintada reagentes para Leptospira spp. mostram a complexidade da cadeia epidemiológica da região. É necessário entender a cadeia epidemiológica da leptospirose no contexto da fragmentação florestal, sabendo-se que a presença da leptospirose geralmente é associada á uma saúde ecológica empobrecida do meio ambiente (VINETZ et al., 2005).

\subsection{BRUCELOSE}

Perante esses resultados evidencia-se que os taiassuídeos tiveram contato com Brucella abortus. Comparando as duas espécies de taiassuídeos deste estudo, identificamos maior número de queixadas reagentes para brucelose do que catetos. Esse fato pode ser explicado perante a biologia das espécies. Os queixadas formam os maiores bandos e a maior biomassa forrageadora de todos os ungulados neotropicais, frequentemente deslocando-se longas distâncias (FRAGOSO, 1994), desta forma, a espécie se torna mais suscetível a contato com patógenos. 
Os animais do PEMD estão mais em contato com esses patógenos do que os animais do fragmento, apesar de não haver diferença significativa no número de animais reagentes entre o PEMD e fragmentos. Isso gera um paradoxo, pois os fragmentos florestais, como regiões mais alteradas que o PEMD e com maior pressão antrópica e adensamento populacional de animais domésticos em seu entorno, teriam a maior probabilidade de encontrar animais reagentes para doenças infecto-contagiosas. Porém, a forma de ocupação do entorno do PEMD continua a mesma desde a década de $30 \mathrm{com}$ sítios e fazendas distribuídos na face norte e leste, com exceção do lado oeste do PEMD que até o ano de 1997 era um grande latifúndio com criação extensiva de gado de corte, até se tornar o assentamento Ribeirão Bonito (COSTA; FUTEMMA, 2006).

O desmatamento do Pontal foi intensificado em 1946 (DITT, 2002), sendo que a ocupação do entorno dos fragmentos de mata restantes teve início a partir deste ano, e era caracterizado por grandes latifúndios. Sendo assim, a população de animais silvestres do PEMD teve maior tempo de exposição a patógenos provenientes de animais domésticos do que os animais silvestres dos fragmentos florestais. As tentativas de isolamento de Brucela spp. foram inconclusivas neste estudo. Entretanto, seria muito importante a caracterização molecular da espécie de Brucella nos animais silvestres e domésticos, para a compreensão da cadeia epidemiológica da brucelose na região.

Em queixadas de vida livre no Mato Grosso do Sul, dois animais dentre sete amostrados foram reagentes para brucelose (ITO et al., 1998), tendo sido usado o mesmo método diagnóstico deste estudo. Em catetos em cativeiro na Amazônia, dois animais dentre $n=41$ amostrados forma reagentes para Brucella spp (MAYOR et al., 2006).

Uma onça pintada capturada no PEMD foi reagente para brucelose. Esse indivíduo era monitorado por telemetria e verificou-se que ele rotineiramente predava gado no entorno do PEMD e atravessava o rio Paranapanema para predar gado em fazendas do Paraná. Sendo assim, pode haver a possibilidade desta onça ter entrado em contato com o patógeno por estar em contato freqüente com o gado destas propriedades.

Os bovinos do entorno dos fragmentos pequenos foram proporcionalmente mais reagentes para brucelose que os bovinos amostrados no entorno do PEMD e fragmentos grandes. A fazenda Santa Mônica é uma propriedade de criação 
extensiva de gado de corte. Os animais reagentes amostrados não haviam sido vacinados para brucelose, descartando a possibilidade do resultado positivo ser uma reação por título vacinal. Os queixadas capturados no fragmento Santa Mônica não foram reagentes para brucelose, bem como os catetos amostrados nos fragmentos Santa Zélia e Ribeirão Bonito.

A prevalência de brucelose é baixa na região do Pontal do Paranapanema, e provavelmente é devido ao Programa Nacional de Controle e Erradicação da Brucelose e Tuberculose (PNCETB), onde O PNCEBT instituiu em 2001 a vacinação obrigatória contra brucelose bovina e bubalina em todo o território nacional e definiu uma estratégia de certificação de propriedades livres ou monitoradas onde essas enfermidades são controladas com rigor (BRASIL, 2008).

\subsection{IMUNODEFICIÊNCIA FELINA E LEUCEMIA FELINA}

Os felídeos selvagens amostrados e os felinos domésticos não foram reagentes para imunodeficiência felina e leucemia Felina. Entretanto, os níveis de FeLV e FIV oscilam largamente, devido aos diferentes estágios de infecção, ocasionando baixas quantidades de antígenos e anticorpos (ROJKO; HARDY, 1994).

Também, durante a fase imunossupressiva da FIV, os anticorpos podem não estar mais sendo produzidos pelo hospedeiro em níveis detectáveis pelo teste diagnostico. Tem sido demonstrado que o sistema imune do gato doméstico pode inibir a replicação viral e ainda assim ser um reservatório viável para o vírus (LEVY et al., 2005)

O FeLV é mantido em mais espécies de felinos, sendo que a maioria dos casos confirmados são originados de cepas de gatos domésticos (KENNEDYSTOSKOPF, 1999); há relatos na epidemiologia de FeLV envolvendo o gato selvagem europeu e há uma cepa enzoótica característica dessa população (LEUTENEGGER et al., 1999). Portanto, podemos assumir que todos os resultados obtidos nas quatro espécies amostradas no PEMD havia níveis detectáveis do antígeno p27. Entretanto, há uma extensa gama de amino ácidos entre as várias FIV lentiviroses o que torna os falsos negativos uma possibilidade (KENNEDY- 
STOSKOPF, 1999). Provavelmente, há a possibilidade de que as amostras de felídeos selvagens que carreiam cepas de FIV não terem sido reconhecidas pelo ELISA indireto utilizado.

Entretanto, para um estudo inicial dessas doenças a técnica diagnóstica utilizada ELISA indireto, através de kits comerciais Iddex para detecção de anticorpos para FIV e Felv, ainda é considerada o teste mais adequado (BARR, 1995; KENNEDY-STOSKOPF, 1999).

Em estudo na Arábia Saudita em gatos do deserto (Felis margarita) dois animais foram reagentes para FeLV utilizando ELISA através de kits comerciais Iddex (OSTROWSKY et al., 2003), e com esse mesmo teste comercial, foi detectado anticorpos para FIV no gato selvagem europeu (FROMONT et al., 2000; LEUTENEGGER et al., 1999). O teste de FeLV procura a proteína solúvel p27 na circulação periférica, sendo que a presença desta proteína está correlacionada com uma infecção viral ativa e potencial da transmissão viral. O teste para FIV usa uma proteína sintética p24 para capturar anticorpos na amostra.

A presença de anticorpos para FIV sugere uma infecção persistente e a capacidade de transmitir o vírus. Resultados negativos para FeLV e FIV indicam que o antígeno p27 e o anticorpo FIV- específico não foram detectados na amostra e sugere que o animal não está infectado. O principal questionamento seria uso errado da técnica ou falha do teste nas diferentes fases de infecção do animal. Durante estágio recente da infecção por FIV, resultados negativos podem ocorrer devido a um tempo insuficiente na soroconversão, e o similar ocorre na fase aguda da infecção por FeLV, onde os níveis do antígeno p27 podem estar abaixo do limite de detecção do teste (FILONI et al., 2003). Na fase final da infecção por FIV, a imunossupressão é tão severa que inibe a produção de anticorpos (BARR, 1995). O teste possui um controle, o que elimina o questionamento de erro operacional.

Com base nos dados obtidos, pode-se observar que as infecções por FIV e FeLV por enquanto são raras na região e que medidas de controle para que esses agentes não sejam introduzidos devem ser tomadas. O uso de outros métodos diagnósticos como PCR devem ser utilizados, e continuação de um monitoramento sorológico na região. A crescente proximidade de gatos domésticos nos habitats de felídeos selvagens aumenta o risco de contato direto e transmissão de doenças inter espécies (OSTROWSKI et al., 2003). Os futuros planos de manejo para as UC's da região deve considerar a orientação e educação dos proprietários quanto ao modo 
de criação, sanidade e alimentação dos gatos domésticos e sobre a importância do controle populacional desses animais para evitar o aumento dessa população no entorno da unidade de conservação. 


\section{CONCLUSÕES}

A fragmentação florestal cria ilhas isoladas que diminuem o tamanho da população, mas paradoxalmente aumentam a densidade local dos animais que são forçados a competir por recursos em habitats altamente concentrados (BURKEY, 1999). Esse quadro é retratado na região do Pontal do Paranapanema, onde populações de queixadas se concentram em fragmentos pequenos, como no fragmento florestal Santa Mônica. O tamanho reduzido de alguns fragmentos, que não tem tamanho de área suficiente para um grupo de queixadas, mostram que a população de animais selvagens do Pontal continua passando por um " gargalo", e a dinâmica fonte - sumidouro ainda está ocorrendo nesta região como o exemplo do fragmento florestal Santa Mônica.

Fragmentos florestais com alta densidade animal são invariavelmente mais susceptíveis a epidemias devido ao aumento do contato de indivíduos da mesma espécie (BRADSHAW; BROOK, 2005).

Cenários que permitem dispersão limitadas entre ilhas florestais (metapopulação) tem sido pouco estudados no seu contexto epidemiológico. Em modelos, há normalmente um controle da troca entre o número de migrantes entre os fragmentos e o potencial impacto da transmissão de doenças (REED, 2004).

Quando a dispersão é muito baixa (similar ao cenário ilhas isoladas), a transmissão de doenças será atenuada; entretanto, a resistência a infecção em animais isolados em fragmentos de floresta não irá se desenvolver, tornando-os suscetíveis á extinção local atravéz de patógenos oportunistas. Com altas taxas de troca entre fragmentos de floresta isolados entretanto, há uma outra ameaça de uma epidemia rapidamente disseminada entre os fragmentos florestais. Paradoxalmente, altas taxas de migração favorecem a recolonização de fragmentos florestais que estão enfrentando extinção local de algumas espécies animais (HANSKI, 1997).

Em um sistema fechado, o cenário epidemiológico mais favorável é um número intermediário de sub populações mistas.Entretanto, estes modelos teóricos não se aplicam totalmente ao Pontal do Paranapanema, onde há um constante e potencial fluxo de patógenos na paisagem rural. O contínuo fluxo e alta densidade de animais domésticos que são mais suscetíveis a epidemias (MARIANTE; EGITO, 
2002), mostra que no cenário do Pontal do Paranapanema, as epidemias tem maior chance de virem da matriz antrópica mais rapidamente do que entre os animais silvetres que se movem entre os fragmentos florestais.

É urgente um programa de extensionismo rural visando o incremento da saúde animal doméstica que vive no entorno do PEMD e fragmentos florestais. As altas prevalências de leptospirose em animais domésticos e silvestres, e outras doenças infecto contagiosas que possam estar presentes no estoque animal doméstico da região devem ser minimizadas com um trabalho de medicina preventiva com os produtores rurais. A presença de zoonoses como a leptospirose e brucelose nos animais domésticos são um risco de saúde pública para os proprietários rurais. Um programa de conscientização deve ser realizado na região perante os resultados desse estudo, envolvendo saúde pública, controle populacional de cães e gatos, e vacinação dos animais domésticos.

$\mathrm{Na}$ elaboração dos planos de manejo das UCs deve ser incluído diagnóstico da fauna selvagem a patógenos, e conhecer o risco existente de doenças infectocontagiosas nos animais domésticos que vivem no entorno das UCs.

O uso de sorologia é o primeiro passo para saber o a presença e ausência de alguns patógenos. Estudos de monitoramento de fauna selvagem devem ser realizados periodicamente, e o uso de técnicas sorológicas e moleculares devem ser utilizadas em um futuro estudo para melhor entendimento da epidemiologia de alguns agentes na população silvestre e doméstica e sua origem.

A paisagem fragmentada do Pontal do Paranapanema sofreu modificações bruscas em um curto período de tempo. Os resultados deste estudo demonstram que o modo de ocupação e manejo dos animais domésticos no entorno dos remanescentes florestais são fatores a serem levados em consideração para estudos envolvendo conectividade florestal e saúde do ecossistema. Informações como tamanho do fragmento florestal e seu estado de preservação devem ser aliados ao conhecimento da epidemiologia de doenças infecto contagiosas nas populações silvestres e domésticas de uma mesma região.

A emergência de algumas doenças virais pelo mundo exigiu um novo conhecimento da relação entre degradação ecológica e surgimento de doenças.

A preocupação com a saúde em um contexto holístico, apesar de parecer óbvia, só recentemente está sendo reconhecida como um objeto de rigorosa 
examinação científica. A Medicina da Conservação está construindo os avanços deste conhecimento na área da saúde e ciências ecológicas para futuros pesquisadores trabalharem tendo esta conexão como peça chave para mitigar futuras ameaças a saúde ecológica. 


\section{REFERÊNCIAS}

ACHA, P. N.; SZYFRES, B. Zoonosis y enfermidades transmissibles comunes al hombre y los animales. Washington: Organizacion Panamericana de la Salud, 1986. p. 502-506. (Publicacion científica, 503).

AGUIRRE, A. A.; HANSEN, D. E., STARKEY, E. E.; MC LEAN, R. G. Serologic survey of wild cervids for potential disease agents in selected national parks in United States. Preventive Veterinary Medicine. v. 21, p. 313- 322, 1995.

AGUIRRE, A. A.; KEEFE, T. J.; RIEF, J. S.; KASHINSKY, L.;YOCHEM, P. K.; SALIKI, J. T. ; STOTT, J. L. ; GOLDSTEIN, T. ; DUBEY, J. P. ;BRAUN, R.; ANTONELIS, G. Infectious disease monitoring of the endangered Hawaiian monk seal. Journal of Wildlife Disease, v. 43, n. 2, p.57-58, 2007

AGUIRRE, A. A.; O' HARA, T. M.; SPRAKER, T. R.; JESSUP, D.A. Monitoring the Health and conservation of marine mammals, sea turtles, and their ecosystems. In: AGUIRRE, A. A.; OSTFELD, R. S.; TABOR, G. M.; HOUSE, C.; PEARL, M. C. Conservation Medicine: ecological health in practice. New York: Oxford University Press, 2002. p. 79-94.

ALTRICHTER, M. AND BOAGLIO, G. I. Distribution and relative abundance of peccaries in the Argentine Chaco: associations with human factors. Biological Conservation, v. 116, p. 217-225, 2004.

APPEL, M.; REGGIARDO, C.; SUMMERS, B. A.; PEARCE-KELLING, S.; MÁRE, C. J.; NOON, T. H.; REED, R. E.; SHIVELY, J. M.; ORVELL, C. Canine distemper virus infection and encephalitis in javelinas (collared peccaries). Archives of Virology, v. 119, p.147-152, 1991.

APPEL, M., SHEFFY, B. E.; PERCY, D. H. Canine distemper virus in domesticated cats and pigs. American Journal of Veterinary Research, v. 35, p. 803-806, 1974.

APPEL, M. J. G. Canine distemper virus. In: APPEL, M. J. G. (Ed.). Virus infections of carnivores. Amsterdan: Elsevier Science, 1987. p. 133-159.

BARBRAUD, C.; NICHOLS, J. D.; HINES, J. E.; HAFNER, H. Estimating rates of local extinction and colonization in colonial species and an extension to the metapopulation and community levels. Oykos, v. 101, p.113-126, 2003. 
BARCELLOS, C.; SABROZA, P. C. O lugar por detrás do caso: risco de leptospirose e condição ambiental associada em uma inundação no Rio de Janeiro. Cadernos de Saúde Pública v. 17, p. 59-67, 2001.

BARR, M. C.; FIV, FeLV, and FIPV: interpretation and misinterpretation of serological test results. Seminary of Veterinary Medicine Surgery in Small Animals. v. 11, p.144-153, 1995.

BARROS-BATTESTI, D. M.; ARZUA, M.; BECHARA, G. H. Carrapatos de importância médico-veterinária da Região Neotropical: um guia ilustrado para identificação de espécies. São Paulo: Vox/ International Consortium on Ticks and Tick-borne Diseases (ICTTD-3)/Butantan, 2006. p. 45-54.

BELDOMÉNICO, P. M.; BALDI, J. C.; ANTONIAZZI, L. R.; ORDUNA, G. M.; MASTROPAOLO, M.; MACEDO, A. C.; RUIZ, M.F.; ORCELLET, V.; PERALTA, J. L.; VENZAL, J. M.; MANGOLD, A. J.; GUGLIELMONE, A. A. Las garrapatas argentinas del género Amblyomma (Acari: Ixodidae): Ixodid ticks (Acari:Ixodidae) present at parque nacional El Rey, Argentina. Neotropical Entomology, v. 32, p. 273-277, 2003.

BLAZIUS, R. D.; ROMÃO, P. R. T.; BLAZIUS, E. M. C. G.; SANTOS DA SILVA, O. Ocorrência de cães errantes soropositivos para Leptospira spp. na Cidade de Itapema, Santa Catarina, Brasil. Cadernos de Saúde Pública, v. 21 n. 6, p. 160, 2005.

BODMER, R.E.; AQUINO, R.; PUERTAS, P.; REYES, C.; FANG, T.; GOTTDENKER, N. Manejo y Uso Sustentable de Pecaríes en la Amazonia Peruana. No. 18. De la Comisión de Supervivencia de Especies. Lima: 1996. Occasional Paper.

BRADSHAW, C. J. A. ; AND BROOK, B. W. Disease and the devil: densitydependent epidemiological processes explain historical population fluctuations in the Tasmanian devil. Ecography, v. 28, n. 2, p. 181-190, 2005.

BRANDÃO, M.L. Helmintos de mamíferos da região do Parque Nacional Serra da Capivara, sudeste do Piauí: Diversidade e influências antrópicas. Tese de Mestrado. Fio Cruz, 2007.

BRASIL, Programa Nacional de controle e erradicação da brucelose e tuberculose. Ministério da Agricultura, Pecuária e Abastecimento. Brasília, 2008. Disponível em Http://Www.Agriculturda.Gov.Brl. Acesso em 30 Mai 2008. 
BROWN, J. H. ; HESKE, E. J. Control of a desert-grassland transition by a keystone rodent guild. Science, v. 250, p. 1705-1707, 1990.

BURKEY, T. V. Extinction in fragmented habitats predicted from stochastic birthdeath processes with density dependence. Journal of Theoretical Biology, v 199, n. 4, p. 395-406, 1999.

CALEY, P. ; HONE, J. Disease transmission between and within species, and the implications for disease control. Journal of Applied Ecology , v. 41, p. 94-104, 2004.

CARPENTER, M. A. ; BROWN, E. W. ; CULVER, M. ; WARREN, E. J. ; PECONSLATTERY, J. ; BROUSSET,D. ; O'BRIEN, S. J. Genetic and phylogenetic divergence of feline immunodeficiency virus in the puma (Puma concolor). Journal of virology, v.70, p. 6682-6693, 1996.

CHANG, H. H.; EIDSON, M.; NOONAN-TOLY, C.; TRIMARCHI, C. V.; RUDD, R.; WALLACE, B. J.; SMITH, P. F.; MORSE, D. L. Public health impact of reemergence of rabies, New York. Emerging Infectious Disease, v. 8, p. 909-913, 2002.

CLEAVELAND, S., G. R.; HESS, A. P.; DOBSON, M. K.; LAURENSON, H. I.; CALLUM, M. C.; ROBERTS, M. G.; WOODROFFE, R. The role of pathogens in biological conservation. In: HUDSON, P. J.; RIZZOCI, A.; GRENFELL, B. T.; HEESTERBEEK, H.; DOBSON, A. P. The ecology of wildlife diseases. Oxford: Oxford University Press, 2003. p. $39-150$.

CORN, J. L.; LEE, R. M.; ERICKSON, G. A.; MURPHY, C. D. Serologic survey for evidence of exposure to vesicular stomatitis virus, pseudorabies virus, brucellosis and leptospirosis in collared peccaries from Arizona. Journal of Wildlife Diseases, v.23, p. 551-557, 1987.

CORREA, S. H. R.; VASCONCELLOS, S. A.; MORAIS, Z. Epidemiologia da leptospirose em felinos silvestres da Fundação Parque Zoológico de São Paulo. In: CONGRESSO E XII ENCONTRO DA ABRAVAS, 2004, Jaboticabal., 2004, p.15.

COSTA, R. C.; FUTEMMA,C. R. T. Racionalidade com compromisso: os assentados do Ribeirão Bonito (Teodoro Sampaio - SP) e o projeto de conservação ambiental. Ambiente \& Sociedade, v. 9, n. 1, p. 55-57, 2006. 
CUBAS, Z. S. Special challenges of mantaining wild animal in captivity in south america. In: FOWLER, M.E. Wildlife husbandry and diseases. Paris: Office of International des epizooties, 1996. n.1, p. 267-288. (Scientific and technical review, 15)

CULLEN, L.; ABREU, K. C.; SANNA, D.; NAVA, A .F. D. Jaguars as landscape detectives for the upper Paraná River corridor, Brazil. Natureza e Conservação, v. 3, p. 43-58, 2005.

CULLEN, L.; BODMER, R. E.; VALLADARES-PADUA, C. Effects of hunting in habitat fragments of the Atlantic forests, Brazil. Biological Conservation, v.95, p. 49-56, 2000.

CULLEN JR. L.; BODMER, R. E.; VALLADARES-PADUA, C.; Ecological consequences of hunting in Atlantic forest patches, São Paulo, Brazil., Oryx. v. 35, n. 2, p. 137-144, 2001.

CUMBERLAND, P.; EVERARD, C. O.; LEVETT, P. N. Assesment of the efficacy of an IgM-ELISA and microscopico agglutination test (MAT) in the diagnosis of acute leptospirosis. American Journal of Tropical Medicine and Hygiene, v. 61, n. 5, p. 731-734, 1999.

DEEM, S. L.; EMMONS, L. H. Exposure of free-ranging maned wolves (Chrysocyon brachyurus) to infectious and parasitic disease agents in the Noel Kempff Mercado National Park, Bolivia. Journal of Zoo and Wildlife Medicine, v 36,n.2, pp. 192197, 2005.

DENN, S. L.; KARESH, W. B.; WEISMAN, W. Putting theory into practice: wildlife heath in conservation. Conservation Biology, v. 15, n. 5, p. 24-33, 2001.

DICKESON, D.; LOVE, D. N. A serological survey of dogs, cats and horses in southeastern Australia for leptospiral antibodies. Australian Veterinary Journal, v.70, n.10, p. 389-390, 1993.

DIDHAM, R. K.; GHAZOUL, J.; STORK, N. E.; DAVIS, A. J. Insects in fragmented forests: a functional approach. Trends in ecology and evolution, v. 11, p. 255-260, 1996.

DIRZO, R.; MIRANDA, A. Altered patterns of herbivory and diversity in the forest understory: a case study of possible consequences of contemporary defaunation. In: PRICE, W. P.; LEWINSOHN, T. M.; FERNANDES, G. W.; BENSON, W. W. Plant- 
animal interactions: evolutionary ecology in tropical and temperate regions. John Wiley \& Sons, 1991, p. 273-287

DITT, E. H. Avaliação da nova paisagem do Pontal do Paranapanema. In: Fragmentos florestais do Pontal do Paranapanema. São Paulo: Selo Universidade, 2002. p. 38-40.

DRUMOND, M.A.; LIMA, P.C.F.; SOUZA, S.M.; JOSÉ, L.M. Sociabilidade das espécies florestais da Caatinga em Santa Maria da Boa Vista-PE. Boletim de Pesquisa Florestal, n.4, p.47-59, 1982.

EBANI, V. V.; CERRI, D. ; POLI, A. ;ANDREANI, E. Prevalence of Leptospira and Brucella antibodies in wild boars (Sus scrofa) in Tuscany, Italy. Journal of wildlife diseases, v. 39, n. 3, p. 718-722, 2003.

ENGLISH, R. V.; NELSON, P.; JOHNSON, C. M.; NASISSE, M.; TOMPKINS, W. A.; TOMPKINS, M. B. Development of clinical disease in cats experimentally infected with feline immunodeficiency virus. Journal of Infectious Diseases, v. 170, p. 543-552, 1994.

FAHRIG, L.; MERRIAN, G. Conservation of fragmented populations. Conservation Biology, v. 8, n. 1, p. 50-59, 1993.

FAINE, S. Leptospira and Leptospirosis. Boca Raton: CRC Press, 1994. 353 p.

FAVERO, M.; PINHEIRO, S. R.; VASCONCELLOS, S. A., MORAIS, Z. M.;

FERREIRA, F.; FERREIRA NETO, J. S. Leptospirose bovina - Variantes sorológicas predominantes em colheitas efetuadas no período de 1984 a 1997 em rebanhos de 21 estados do Brasil. Arquivos do Instituto Biológico, São Paulo, v.68, n.2, p. 29$35,2001$.

FILONI, C.; ADANIA, H. C.; DURIGON, E.; CATÃO-DIAS, J. Serosurvey for feline leukemia virus and lentiviruses in captive small neotropic felids in São Paulo state, Brazil. Journal of Wildlife Diseases, v. 34, n.1, p. 65-68, 2003.

FILONI, C., CATÃO-DIAS, J.L., BAY, G.; DURIGON, E.L.; JORGE, R.S.P.; LUTZ, H.; HOFMANN-LEHMANN, R. First Evidence of Feline Herpesvirus, Calicivirus, Parvovirus, and Erlichia Exposure in Brazilian Free-ranging Felids. Journal of Wildlife Diseases v.42, n. 2, p. 470-477, 2006. 
FIORELLO, C. V.; DEEM, S. L.; GOMPPER, M.; DUBOV, E. J. Seroprevalence of pathogens in domestic carnivores on the border of Madidi National Park, Bolivia Animal Conservation, v. 7, p. 45-54, 2004.

FOWLER, M. E. Wild swine and peccaries. W.B. Saunders Company, 1993.

FRAGOSO, J. M. Desapariciones locales del baquiro labiado (Tayassu peccari) migracion sobre cosecha o epidemia? In: FANG, T. G.; BODMER, R.; AQUINO, R. ; VALQUI, M. H. Manejo de fauna silvestre en la Amazonia. UNAP-University of Florida-UNDP/GEF-Universidade Mayor de San Andrés, 1997, p. 309-312.

FRAGOSO, J. M. Large mammals and the community dynamics of an Amazonian rain forest. 1994. 209p .PhD Dissertation. University of Florida.

FRENKEL, J. K. AND SOUZA, O. E. Antibodies to toxoplasmosis in Panamanian mammals. Journal of Parasitology, v. 69, p. 244-245, 1983.

FROMONT, E.; ARTROIS, M.;PONTIER, D. Cat population structure and circulations of feline viruses. Acta Oncologica, v. 17, p. 609-620, 1996.

GASCOYNE, S. C.; LAURENSON, M. K..; BORNER, M. Rabies in African wild dogs (Lycaon pictus) in the Serengeti region. Journal of wildlife disease, v.29, p. 396402, 1993.

GONÇALVES, A. S. Causes of spatial genetic structure in mammals: a case study in the Atlantic Forest, Brazil. 2007. 150p. PhD Dissertation. Columbia University.

GREENE, H. W. Species richness in tropical predators. In: Tropical rainforests: diversity and conservation, In: ALMEDA, F., PRINGLE, C.M. Ed. San Francisco, California: California: Academic Sciences, 1988. p. 259-280.

GREENE, C. E.; APPEL, M. J. Canine distemper. In: GREENE, C. E. (Ed.). Infectious disease of the dog and cat. 2. ed. Philadelphia: W.B. Saunders, 1998.p. 9-22.

GREINER, M.; GARDNER, I. A. Epidemiologic issues in the validation of veterinary diagnostic tests. Preventive Veterinary Medicine, v. 45, p. 3-22, 2000. 
GRUVER, K. S.; GUTHRIE, J. W. Parasites and selected diseases of collared peccaries (Tayasu tajacu) in the Trans-Pecos region of Texas. Journal of Wildlife Disease, v. 32, n. 3, p. 560-562, 1996.

GUERRA NETO, G. Freqüência de anticorpos contra Leptospira spp. em felídeos neotropicais em cativeiro no Brasil, , 2006. 56p. Tese (Mestrado), Universidade Estadual de São Paulo, Jaboticabal, 2006.

GUERRA NETO, G.; GIRIO, R. J. S.; ANDRADE, T. M. Ocorrência de anticorpos para Leptospira spp., felinos neotropicais pertencentes ao Criadouro de Animais Silvestres da Itaipu Binacional e ao Zoológico Municipal Bosque Guarani, Foz do Iguaçu- PR. In: CONGRESSO DE ZOOLÓGICOS DO BRASIL, 2701, 2003. Bauru, 2003.

GUGLIELMONE, A. A.; VIÑABAL, A. E. Claves morfológicas dicotómicas e información ecológica para la identificación de garrapatas del gênero Amblyomma Koch, 1844 de la Argentina. Revista de Investigaciones Agropecuárias,v. 25, p. 39-67, 1994.

HAAS, L., HOFER, H., EAST, M.. Canine distemper virus in Serengeti spotted hyaenas. Veterinary Microbiology, v. 49, p. 147-152, 1996.

HANSKI, I. Metapopulation Dynamics: from concepts and observations to predictive models. London: Academic, 1997. p. 61-91.

HARDER, T. C.; KENTER, M.; VOS, H.; SIEBELINK, K.; HUISMAN, W.; VAN AMERONGEN, G.; ORVELL, C.; BARRETT, T.; APPEL, M. J. G; OSTERHAUS, D. M. E. Canine distemper virus form diseased large felids: biological properties and phylogenetic relationships. Journal of General Virology, v. 77, p. 397-405, 1996.

HILL, M.O.Diversity and eveness: a unifying notation and its consequences. Ecology, v.54, p. 427-432, 1973.

HOBBS, R. J. Landscape ecology and conservation: moving from description to application. Pacific Conservation Biology, v. 1, p. 170-177, 1994.

HOLMES, J. C. Parasites as threats to biodiversity in shrinking ecosystems.

Biodiversity and Conservation, v. 5, p. 1975-1983, 1996.

HOOF, G. L.; BIGLER, W.; PROCTOR, S.; STALLINGS, L. P. Epizootic of canine distemper virus infection among urban raccoons and gray foxes. Journal of Wildlife Disease, v. 10, p. 423-428, 1974. 
HURLBERT, S. H. The nonconcept of species diversity: a critique and alternative parameters. Ecology, v.52, p. 577-586, 1971.

IBAMA. Lista nacional das espécies da fauna brasileira ameaçadas de extinção (Versão atualizada), 2003. Disponível em:

<http://www.mma.gov.br/port/sbf/fauna/index.cfm>. Acesso em: 14 maio 2007.

ITO, F. H.; VASCONCELLOS, S. A.; BERNARDI, F.; NASCIMENTO, A. A.; LABRUNA, M. A.; ARANTES, I. G. Evidência sorológica de brucelose e leptospirose e parasitismo por ixodídeos em animais silvestres do pantanal sul-mato-grossense. Ars. Veterinária: Revista de Medicina Veterinária e Zootecnia Unesp,SP., Jaboticabal, SP, v. 14, n. 3, p. 302-310, 1998.

IUCN 2007 IUCN Red list of threatened species. Disponível em: $<$ www.iucnredlist.org>. Acesso em: 23 mar 2008.

JACOB, A. Ecologia e conservação da jaguatirica (Leopardus pardalis) no Parque Estadual Morro do Diabo, Pontal do Paranapanema, SP. (Mestrado em Ciências Florestais seminário avançado) - Universidade de Brasília Faculdade de Tecnologia Departamento de Engenharia Florestal, Brasília, 2002

JORGE, R. S. P. Caracterização do estado sanitário dos carnívoros selvagens da RPPN SESC Pantanal e de animais domésticos da região. $119 \mathrm{f}$. Tese (Doutorado em Ciências) - Faculdade de Medicina Veterinária e Zootecnia, 2008 Universidade de São Paulo, São Paulo, 2008.

KAPOS, V. E. ; WANDELLI, J. ; CAMARGO, D. ; GANADE, G. Edge-related changes in environmental and plant responses due to forest fragmentation in central Amazonia. In: LAURANCE, W. F.; BIERREGAARD, R. O. Tropical forest remnants: ecology, management, and conservation of fragmented communities. Chicago: University of Chicago Press, 1997. p. 33-44.

KARESH, W. B.; UHART, M.; PAINTER, L.; WALLACE, R.; BRASELTON, E.; THOMAS, L.A.; HOUSE C.; MCNAMARA, T.; GOTTDENKER, N. Health evaluation of white-lipped peccary populations in Bolivia. In: AAZVIAAWV Annual Meeting. 1998, Philadelphia, USA. , 1998. 
KENNEDY-STOSKOPF, S. Emerging viral infections in large cats. In: FOWLER, M. E.; MILLER, R. E. Zoo and wild animal medicine, $4^{\text {th }}$ ed, Philadelphia: W. B. Saunders, 1999. p. 401-410.

KENNETH, A.; SCHMIDT, A.; OSTFELD, R. S. Biodiversity and the dilution effect in disease ecology, Ecology, v. 82, n. 3, p. 609-619, 2001.

KEUROGHLIAN, A.; EATON, P. D.; LONGLAND, S. W. Area use by white-lipped and collared peccaries (Tayassu pecari and Tayassu tajacu) in a tropical forest fragment. Biological Conservation, v. 120, n. 3, p. 411-425, 2004.

LABRUNA, M.B.; CAMARGO, L. M. A.; SCHUMAKER, T. S.; CAMARGO,E. P. Parasitism of domestic swine (Sus scrofa) by Amblyomma ticks (Acari: Ixodidae) on a farm at Monte Negro, Western Amazon. Brazil Journal of Medical Entomology v. 39, n. 2, p. 241-243, 2002.

LARSSON, C. E.; SANTA ROSA, C. A.; LARSSON, M. H.; BIRGEL, E. H.; FERNANDES, W. R.; PAIM, G.V. Laboratory and clinical features of experimental feline leptospirosis. International Journal of Zoonosis, v. 12, n. 2, p.111-119, 1985.

LAURANCE, W. F. Edge effects in tropical forest fragments: application of a model for the design of nature reserves. Biological Conservation, v. 57, p. $205-219$, 1991.

LAURENSON, K.; SILLERO-ZUBIRI, C.; THOMPSON, H.; SHIFERAW, F.;THIRGOOD, S.; MALCOLM, J. Disease as a threat to endangered species: ethiopian wolves, domestic dogs, and canine pathogens. Animal Conservation, v. 1, p. 273-280, 1998.

LEIGHTON, F.; FERGUSON, M.; GUNN, A.; HENDERSON, E.; STENHOUSE, G. Canine distemper in sled dogs. Canadian veterinary journal, v. 29, p. 299, 1988.

LEUTENEGGER, C.; HOFMANN-LEHMANN, R.; RIOLS, C.; LIBEREK, M.; WOREL, G. LUPS, P.; FEHR, D.; HARTMANN, M.; WEILENMANN. P.; LUTZ, H. Viral infections in free-living populations of the european wildcat, Journal of Wildlife Diseases, v. 35, n. 4, p. 678-686, 1999.

LEVETT, P. N. "Leptospirosis." Clinical Microbiology Reviews, v.14, n.2, p. 296326, 2001. 
LEVY, J.; RICHARDS, J.; EDWARDS, D. Panel on Feline Retrovirus Testing and Management. In: Report of the American Association of Feline Practitioners and Academy of Feline Medicine Advisory,Boston, 2005

LINARDI, P.M.; BOTELHO, J.R.; RAFAEL, J.A.; VALLE, C.M.C.; CUNHA, A.; MACHADO, P.; Ectoparasitos de pequenos mamíferos da llha de Maracá, Roraima, Brasil. I. Ectoparasitofauna, registros geográficos e de hospedeiros. Acta Amazonica 21: 131-140, 1991.

LISBÔA LOPES, C. M.; CERQUEIRA LEITE, R.; LABRUNA, M. B.; OLIVEIRA P.R.; BORGES, L.M.F.; RODRIGUES, Z.B.; ÁVILA DE CARVALHO, H.; FREITAS, M.C.; Host Specificity of Amblyomma cajennense (Fabricius, 1787) (Acari: Ixodidae) with Comments on the Drop-off Rhythm. Memórias do Instituto Oswaldo Cruz, Rio de Janeiro, v. 93, n.3, p. 347-351, 1998.

LORD, V. R.; LORD, R. D.; Brucella suis infection in collared peccaries in Venezuela. Journal of Wildlife Diseases, v. 27, p. 477-481, 1991.

LUDWIG, J. A. ; REYNOLDS, J. F. Diversity Indices, In: Statistical Ecology, Wiley Interscience, 1988, cap. 8. p. 85.

LURIA, A.; BRIAN, J.; LEVY, J. K.; LAPPIN, M. R.; BREITSCHWERDT, E. B.; LEGENDRE, A. M.; HERNANDEZ, J. A.; GORMAN, S. P.; LEE, I. T. Prevalence of infectious diseases in feral cats in Northern Florida. Journal of Feline Medicine and Surgery, v. 6, p. 287-296, 2004.

LYMBERY, A. J. Parasites and ecosystem health. International Journal for Parasitology, v. 35, p.703, 2005. MAGURRAN, A. E. Ecological diversity and its measurement. Princeton University Press, Princeton: New Jersey, 1988. p.525

MAINKA, S.A. ;QIU, X. ; HE, T. Serologica survey of giant pandas (Ailuropoda melanoleuca) and domestic dogs and cats in The Wolong Reserve, China. Journal of Wildlife Disease, v. 30, n.1, p. 86-89, 1994

MANGINI, P.R.; GASINO-JOINEAU, M.E.; CARVALHO-PATRICIO, M.A.; FORTES, M.; GONÇALVES, M.; MARGARIDO, T.; KLEMZ, C.; Avaliação da incidência de doenças infecto contagiosas em populações selvagens e cativas de Tayassu pecari, na região de quedas do iguaçu-Paraná.In: CONGRESSO DA ABRAVAS, 7. ., 1998,Aguas de São Pedro, SP. 1998, p. 24-25. 
MARCHIORI FILHO, M.; GIRIO, R. J. S.; LUI, J. F.; MATHIAS, L. A.; BRASIL, A. T. R. Estudo sorológico para leptospirose em populações de diferentes grupos genéticos de javalis (sus scrofa scrofa,Linnaeus, 1758) dos estados de São Paulo e Paraná Arquivos do Instituto Biológico, São Paulo, v. 69, n. 3, p. 9-15, 2002.

MARGARIDO, T. C.; MANGINI, P. R. Order artiodactyla, family Tayassuidae (peccaries). In: FOWLER, M. E.; CUBAS, Z. S. Biology, Medicine and Surgery of South American wild animals, lowa,. Ed.. lowa State University Press, 2001. p. 377-391.

MARIANTE, A. D. S.; EGITO, A. A. Animal genetic resources in Brazil: Result of five centuries of natural selection. Theriogenology, v. 57, n.1, p. 223-235, 2002.

MARTINS, J. R.; MEDRI, I.; MERI.; OLIVEIRA, C. M.; GUGLIELMONE, A. Ocorrência de carrapatos em tamanduá-bandeira (Myrmecophaga tridactyla) e tamanduámirim (Tamandua tetradactyla) na região do Pantanal Sul MatoGrossense, Brasil. Ciência Rural, v. 24, n.1, p. 293-295, 2004.

MAYOR, P.; LE PENDU, Y.; GUIMARÃES, B. D. A.; SILVA J.V.; TAVARES, H. L.; TELLO, M. A.; WASHINGTON, P.; LO'PEZ-BE'JAR, M. A.; FERRAN JORI, A. A health evaluation in a colony of captive collared peccaries (Tayassu tajacu) in the eastern Amazon. Research in Veterinary Science, v. 81, n. 2, p. 246-253, 2006.

MEAGHER, M.; MEYER, M. E. On the origin of brucellosis in bison in Yellowstone National Park: a review. Conservation Biology, v.8. p. 645-653, 1994. MENDOZA, P.; MAYOR, P.; GALVEZ, H. A.; CESPEDES, M. J.; JORI, F. Antibodies against Leptospira spp. in captive collared peccaries, Peru. Emerging Infectious Diseases, v. 13, n. 5, p. 793-794, 2007.

MORGAN, J.; KATZ, S.; MANEA, H.; SASAKI, F. Outbreak of leptospirosis among triathlon participants and community residents in Springfield, Illinois, 1998. Clinical Infectious Diseases v. 34, n.12, p. 1593-1599, 2002.

MURCIA, C. Edge effects in fragmented forests: implications for conservation. Trends in ecology and evolution, v. 10, p. 58-62, 1995.

NASCIMENTO, A. A.; HOPPE, E. G.; MAPELI, E.B. Infecções naturais por helmintos parasitas em catetos (Tayassu tajacu) no Pantanal de Paiaguás, Ms, Brasil. Revista de Parasitologia Tropical, , v.34, p. 45, 2005a. Suplemento Especial 
NASCIMENTO, A. A.; HOPPE, E. G.; MAPELI, E.B. Infecções naturais por helmintos parasitas em queixadas (Tayassu Pecari) no Pantanal de Paiaguás, Ms, Brasil.

Revista de Parasitologia Tropical, v.34, p. 75, 2005b. Suplemento Especial

NAVA, A.F.D.; CULLEN, L.; SANA, D.; NARDI, M.; CACHUBA, K. Primeiras evidências de contato de felídeos neotropicais de vida livre com o vírus da cinomose In: 31 Congresso Anual da Sociedade de Zoológicos do Brasil - SZB, XIV Congresso Anual da Asóciacion latino americana de Parques Zoológicos e Acquários - ALPZA, 14 Encontro da Associação Brasileira de Veterinários de Animais Selvagens - ABRAVAS, São Paulo. Anais. p. 24, 2007, São Paulo.

NAVA, A. F. D. ; PETERKA C. R. L.; BANDEIRA, D. S.; CULLEN, L. Avaliação da prevalência pelo vírus da infecção por leucemia felina (FELV) e imunodeficiência felina (FIV) em felinos domésticos e silvestres na região do Parque estadual Morro do Diabo - SP. In: CONGRESSO, 8 ENCONTRO DA ASSOCIAÇÃO BRASILEIRA DE VETERINÁRIOS DE ANIMAIS SELVAGENS, ABRAVAS, 12., 2004, Jaboticabal.

NAVA, A.; CULLEN, L. Peccaries as sentinel species: conservation, health and training in Atlantic Forest Fragments, Brazil. Suiform Soundings PPHSG Newsletter, v.3, n.2, p.15-16, 2003.

NAVA, S.; LARESCHI, M.; MANGOLD, A.J.; GUGLIELMONE, A. A. Registros de garrapatas de importancia médico-veterinaria detectadas ocasionalmente en la Argentina. Revista FAVE, v. 3, p. 61-65, 2004.

NETO, E. ; BARTOLOMEU, V.; MONTEIRO, P.; SEVERO, A.; D. A. CANCELA, D.A.; FONSECA, L. Avifauna invernante na reserva natural do sapal de Castro Marim e Vila Real de Santo António. In: Congresso do Algarve, 10, 1999. Algarve. Actas do $10^{\circ}$ Congresso do Algarve, p. 455-464.

NETO, JB. ; THATCHER, V.E. Estudos parasitológicos preliminares em tayassuídeos (Tayassu tajacu) na Amazônia Central. Revista Brasileira de Medicina Veterinária. v.8., p. 175-184, 1986.

NOON, T. H.; HEFFELFINGER, J. R.; OLDING, R. J.; WESCHE, S. L.; REGGIARDO, C. Serologic survey for antibodies to canine distemper virus in collared peccary (Tayassu tajacu) populations in Arizona. Journal of Wildlife Diseases, v. 39, n. 1, p. 221-223, 2003

OGUNSEITAN O. Microbial diversity. Austrália: Blackwell Publishing, 2005. 
OIE, OFFICE INTERNATIONAL DES EPIZOOTIES. Terrestrial animal health code, 2004. Disponível em:<http://www.oie.int/eng/normes/mmanual/A 00052.htm> Acesso em: 20 fev.2008.

OLMSTED, R. A.; LANGLEY, R.; ROELKE, M. E.; GOEKEN, R. M.; ADGERJOHNSON, J.; GOFF, J. P.; ALBERT, C.; PACKER, M. K.; LAURENSON,T. M.; CARO, L.; SCHEEPERS, D. E.; WILDT, M.; BUSH, M.; MARTENSON, J. S.; O'BRIEN, S. J. Worldwide prevalence of lentivirus infection in wild feline species: Epidemiologic and phylogenetic aspects. Journal of Virology, v. 66, p. 608-618, 1992.

OSTFELD, R.S.; KEESING, F. Biodiversity and disease risk: the case of Lyme disease. Conservation Biology, v. 14, p. 722-728, 2000.

OSTROWSKI, S.; VAN VUUREN, M.; LENAIN, D. M.; DURAND, A. A. serologic survey of wild felids from Central West Saudi Arabia. Journal of Wildlife Diseases, v. 39, p. 696-701, 2003.

PEET, R.K. The Measurement of diversity. Annual Review of Ecology and Systematics, n. 5, p. 285-307, 1974.

PAULIN, L. M.; FERREIRA NETO, J. S. O combate a brucelose bovina: situação brasileira. Jaboticabal: Funep, 2003.154 p.

PESSUTI, C.; SANTIAGO, M. E. B. Protocolo de manejo para o lobo Guará (Chrysocyon brachyurus) e resposta ao segundo questionário biológico, veterinário e ambiental. Sorocaba: Sociedade dos Zoológicos do Brasil, 1994.

PNUD. Relatórios de desenvolvimento humano RDHS 2006. New York, New York, USA . 2006, p. 65.

RAMOS SILVA, J.; ADANIA, C. H. Carnivora- Felidae (Onça Suçuarana, Jaguatirica, Gato- do- mato). In: CUBAS, Z. S.; SILVA, J.; CATÃO DIAS, J. Tratado de animais selvagens medicina veterinária. São Paulo: Ed Roca, 2007. p.533.

RAMSAY, E. C. Ursidae and hyaenidae. In: FOWLER, M. E.; MILLER, R. E. Zoo and wild animal medicine. 5. ed. Philadelphia: W.B. Saunders, 2003. cap. 51, p. 523-534. 
REED, D. H. Extinction risk in fragmented habitats. Animal Conservation, v.7, p. 181-191, 2004.

REGO DA SILVA, A. A. M. ; MATUSHIMA, E.R.; PINTO, C.M.; BIASI, I. Distemper in Brazilian wild canidae and mustelidae: Case report. Brazilian Journal of Veterinary Animal Science, São Paulo, v. 34, n. 3., p. 156-158, 1997.

REJMÁNKOVÁ, E.; GRIECO, J. ; ACHEE, N.; MASUOKA, P.;POPE, K.;ROBERTS, D.;HIGASHI, R. Freshwater community interacions and malaria. In: COLINGE, S.K.; RAY, C. Disease Ecology: community structure and pathogen dynamics, New York: Oxford University Press, 2006. p. 90-103.

ROELKE-PARKER, M.E.; MUNSON, L. ; PACKER, C.; KOCK, R.; CLEAVELAND, S.; CARPENTER, M.; O'BRIEN, S.J.; POSPISCHIL, A.; HOFMANN-LEHMANN, R.; LUTZ, H.; MWAMENGELE,G.; MGASA; M.N.; MACHANGE, G. A.; SUMMERS, B.A.; APPEL, M. J. G. A canine distemper virus epidemic in Serengeti lions (Panthera leo). Nature v. 379, p. 441-445, 1996.

ROJKO, J. L.; HARDY, W. D. Feline leukemia virus and other retroviruses. In: SHERDING, R.G, (Ed). The Cat: Diseases and Clinical Management. New York: Churchill Livingstone; 1994; p. 263-432.

RUPPRECHT, C. E.; SMITH, J. S.; FEKADU, M.; CHILDS, J. E. The ascension of wildlife rabies: a cause for public health concern or intervention? Emerging Infectious Disease, v. 1, p. 107-114, 1995.

SANTA ROSA, C.A.; SULZER, C.R.; YANAGUITA, R.M.; SILVA, A.S. Leptospirosis in wildlife in Brazil: isolation of serovars canicola, pyrogenes and grippotyphosa. International Journal of Zoonoses, 7. p. 40-43, 1980.

SAUNDERS, D. A.; HOOBS, R. J.; MARGULES, C. R. Biological consequences of ecossystem fragmentation: a review. Conservation Biology, v. 5. p. 18-32,1991.

SCHLOEGEL, L. M.; DASZAK, P.; NAVA, A. Conservation Medicine: tackling the root causes of emerging infectious diseases and seeking practical solutions. Natureza \& Conservação, v. 3, n. 2, p. 135-146, 2005.

SMART, D. L.; TRAINER, D. O.; YUILL, T. M. Serologic evidence of Venezuelan Equine Encephalitis in some wild and domestic populations of Southern Texas. Journal of Wildlife Diseases, v. 11, p. 195-200, 1975. 
SOWLS, L.K., Na introduction to peccaries. In: Javelinas and other peccaries, their Biology, management and use. Texas $\overline{A \& M}$ University Press,1996. p. 4-15.

STANTON, B.J.; BROWN, C. C.; POET, S.; LIPSCOMB, M.; SALIKI, J.;FRASCA JR, $S$. Retrospective differentiation of canine distemper virus in phocids. Journal of Wildlife Diseases, v. 40, n. 1, p. 53-59, 2004.

STIRLING, G.; WISLEY, B. Empirical Relationships between Species Richness, Evenness, and Proportional Diversity .The American Naturalist, v. 158, n. 3, p. 268299, 2001.

SZABÓ, MATIAS P. J. ; LABRUNA, MARCELO B. ; CASTAGNOLLI, KARINA C. , GARCIA MARCOS V.; PINTER, ADRIANO, VERONEZ, VIVIANE A.; MAGALHÃES, GEÓRGIA M.; CASTRO, MÁRCIO B.; VOGLIOTTI, ALEXANDRE. Ticks (Acari:

Ixodidae) parasitizing humans in an Atlantic rainforest reserve of Southeastern Brazil with notes on host suitability . Experimental and Applied Acarology Journal. v. 39, n. 3-4, p. 34, 2006.

TABOR, G. M. In: Defining Conservation Medicine. In: AGUIRRE, A.A.; OSTFELD, R. S.; TABOR, G.M.; HOUSE, C.; PEARL, M. C. Conservation Medicine: ecological health in practice. New York: Oxford University Press, 2002. p. 14-20.

TERBORGH, J. Preservation of natural diversity: the problem of extinction prone species. BioScience, v. 24, p. 715-722, 1974.

TERBORGH, J. The big things that run the world - a sequel to E.O. Wilson. Conservation Biology, v. 2, p. 402-403, 1988.

TERBORGH, J. The role of felid predators in Neotropical forests. Neotropical, v. 2, n.2, p. 3-5, 1990.

TERBORGH, J.; LOPEZ, L.; NUÑEZ, P.; RAO, M.; SHAHABUDDINM, G.; ORIHUELA, G.; RIVEROS, M.; ASCANIO, R.; ADLER, G. H.; LAMBERT, T. D.;

BALBAS, L. Ecological meltdown in predator-free forest fragments. Science, v. 294, p. 1923-1926, 2001.

THIERMANN, A. B. Isolation of leptospiras in diagnosis of leptospirosis. Modern Veterinary Practice, v. 65, n. 758, 1984. 
TRAVASSOS J; VALEJO-FREIRE J. A criação artificial de Amblyomma cajennense para o preparo de vacina contra a febre maculosa. Memórias Instituto Butantan, v. 18 , p. $145-235,1944$

VASCONCELLOS, S.A.; ITO,F.H.; CÔRTES,J.A. Bases para a prevenção da brucelose animal. Comunicação Científica da Faculdade de Medicina Veterinária e Zootecnia da Universidade de São Paulo, São Paulo, v. 11, n. 1, p. 25-36, 1987.

VICENTE J.J.; RODRIGUES, H, O; GOMES, D. C; PINTO, R, M. Nematódeos do Brasil. Parte V: Nematódeos de Mamíferos. Revista Brasileira de Zoologia v.14 p. 1-452, 1977. Suplemento 1.

VINETZ, J. M.; WILCOX, B.A.; AGUIRRE, A.; GOLLIN, L. X.; KATZ, A. R.; FUJIOKA, R. S.; MALY, K.; HORWITZ, P.; CHANG, H. Beyond Disciplinary Boundaries: Leptospirosis as a model of Incorporating Transdisciplinary Approaches to Understand Infectious Disease Emergence. EcoHealth, v. 2, p. 291-306, 2005.

WEBSTER, J. P.; ELLIS, W. A.; MACDONALD, D. W. Prevalence of Leptospira spp in Wild Brown-Rats (Rattus- Norvegicus) on Uk Farms. Epidemiology and Infection, v.11, n .4, p. 195-201,1995.

WHITTAKER, R. H. 1965. Dominance and diversity in land plant communities. Science, v.147, p. 250-260, 1965.

WILCOX, B. A.; GUBLER, D.; Disease ecology and the global emergence of zoonotic pathogens. Journal of Environmental and Health \& Preventive Medicine, v.10, p. 263-272, 2005.

WILLIANS, E.S. Canine distemper. In: WILLIANS, E. S.; BARKER, I. K. Infectious diseases of wild mammals. 3. ed. Ames: lowa State University Press, 2001. cap. 2, p. 50-58.

WILLIANS, E. S.; THORNE, E. T.; APPEL, M.J.G.; BRLITSKY, D. W. Canine distemper in black-footed ferrets (Mustela nigripes) from Wyoming. Journal of Wildlife diseases. v. 24, n. 3, p. 385-398, 1988.

WILSON, E. O. The diversity of life. Cambridge, MA: Harvard University Press,. 1992. 
WOODROFFE, R. Managing disease threats to wild mammals. The Zoological Society of London Natural Conservation, v. 2 , p. 185-193, 1999.

WOODS, G. G.;DONALDS, B.R.; SNYDER, W. A.; HANSON, L. E. Serology of New Mexico javelin ( Pecari angulatus) for evidence of some zoonotic infections. Bulletin Wildlife Disease Association. v. 4, p. 139, 1968.

WOORLEY, M. Retrovirus infections. In: WILLIANS, E.S.; BARKER, I.K. Infectious Diseases of wild mammals. 3. ed., lowa, lowa State University Press, 2001. p .213222.

ZAMKE,L. R.; SALIKI, J.T.; ALASTAIR,P.M.;BREW, S.D.; DAWSON, C.E; VER HOEF, J.M.;FROST, K.J; SMALL, R.J. Serologic survey for brucella spp.,phocid herspesvirus-1, phocid herspesvirus-2, and phocine distemper virus in harbor seals from alaska, 1976-1999. Journal of Wildlife Diseases, v. 42, n. 2, p. 290-300, 2006. 
ANEXO A- Técnicas de diagnóstico: Sorologia

Soroneutralização lenta: A técnica empregada para diagnóstico da cinomose está descrita abaixo:

-Inativar o soro a ser testado em "banho-maria" a $56^{\circ} \mathrm{C}$ por 30 minutos

-Em uma microplaca de 96 orifícios vazia (sem cultura de células), colocar $50 \mu \mathrm{l}$ do soro a ser testado nos dois primeiros orifícios de uma fileira e nos dois primeiros orifícios da fileira ao lado (duplicata). Serão utilizadas 10 colunas da microplaca, totalizando 5 amostras.

-Colocar nos dois primeiros orifícios da $11^{\text {a }}$ fileira $50 \mu \mathrm{l}$ de soro positivo com titulação de anticorpos para cinomose conhecido (controle positivo).

-Colocar $150 \mu \mathrm{l}$ de meio 209 com gentamicina nos orifícios contendo as amostras de soro, resultado da diluição 1:4. Após, colocar $100 \mu \mathrm{l}$ de meio 209 com gentamicina nos orifícios restantes das onze colunas utilizadas.

-Transferir $100 \mu \mathrm{l}$ dos orifícios da segunda fileira para os da terceira e, após homogeneizar devidamente a mistura, transferir para os orifícios da fileira seguinte. Repetir o procedimento até a última fileira. Desprezar os $100 \mu \mathrm{l}$ que sobrarem dos orifícios desta.

- Adicionar aos orifícios contendo o soro diluído, $100 \mu$ da suspensão viral contendo $100 \mathrm{TCID}_{50}$, com exceção dos orifícios da primeira fileira, que serão utilizados como controle do soro.

- Agitar cuidadosamente para homogeneizar a mistura vírus-soro e colocar a placa em estufa úmida a $37^{\circ} \mathrm{C}$, com 3 a $5 \%$ de $\mathrm{CO}_{2}$, por uma hora.

- Aspirar o meio da microplaca contendo cultura de células FEG com 24 horas de crescimento.

- Transferir o conteúdo da microplaca com a mistura soro-vírus para aquela que contém a cultura de células e colocar $200 \mu$ de meio 209 nos primeiros orifícios da última coluna (controle de células).

- Colocar $100 \mu \mathrm{l}$ de meio 209 e $100 \mu \mathrm{l}$ da suspensão viral contendo 100 TCID $_{50}$ nos 4 orifícios restantes da última coluna (controle do antígeno).

- Incubar a placa em estufa úmida a $37^{\circ} \mathrm{C}$, com 3 a $5 \%$ de $\mathrm{CO}_{2}$, por 5 dias.

- Proceder à leitura da placa em microscópio invertido. Deve-se verificar a presença ou ausência de efeito citopático. Sua presença indica a ausência de anticorpos em 
títulos suficientes para neutralizar o antígeno. Desta forma, o título de anticorpos para o vírus da cinomose na amostra testada será definido como diluição que determina completa proteção do tapete celular.

Soroaglutinação microscópica: Os soros testados foram diluídos, através de diluições seriadas, em microplaca de fundo plano. O mesmo volume de antígeno foi adicionado a cada poço e misturado por agitação. As placas são incubadas sem agitação, numa temperatura de $28-30^{\circ} \mathrm{C}$ por $2-4$ horas, tomando-se o cuidado para que não ocorra evaporação.

A suspensão de cada poço foi examinada ao microscópio com uma objetiva de longo alcance em campo escuro para a observação da aglutinação. A aglutinação foi examinada pela observação de agrupamentos e pela densidade residual das leptospiras não-agrupadas. A titulação é identificada pela maior diluição no poço na qual $50 \%$ de aglutinação foi detectada. O ponto de corte adotado foi título 100.

\section{card test, soroaglutinação lenta e 2-mercaptoetanol:}

O card test é uma prova qualitativa, de aglutinação macroscópica, que é realizado apenas com uma diluição e detecta, principalmente, as IgGs. Emprega-se um antígeno corado com Rosa Bengala, tamponado com um pH de 3,65 numa concentração celular de $8 \%$. As amostras são classificadas como positivas ou negativas, não existindo amostra suspeita. Uma reação positiva nesta prova indica que existe uma alta probabilidade de isolar brucela das secreções ou tecidos destes animais e que o animal é um potencial excretor e, portanto perigoso para a saúde do rebanho.

A prova de soroaglutinação lenta é realizada em tubos onde os soros são diluídos a 1:25, 1:50, 1:100 e 1:200 e é utilizado um antígeno padronizado na concentração celular de $0,045 \%$ suspendido numa solução fisiológica a $0,85 \%$ fenolada a $0,5 \%$. As amostras são lidas para a presença de aglutinação ou não, após terem sido incubadas por $48 \mathrm{~h}$ à $37^{\circ} \mathrm{C}$. Esta prova detecta a presença de anticorpos da classe $\lg M$ e $\lg G$, sendo que as $\lg M$ se aglutinam mais fortemente.

O teste de 2-mercaptoetanol é uma prova confirmatória que detecta somente a presença das IgGs. Baseia-se que na presença de radicais tiol, como o 2mercaptoetanol, as moléculas de IgM se degradam em cinco subunidades 
semelhantes e perdem a capacidade de aglutinação e de precipitação.Esta prova deve ser realizada sempre com a prova de soroaglutinação lenta. A prova de 2mercaptoetanol é nterpretada pelas diferenças de títulos entre o soro sem tratamento (soroaglutinação lenta) e com o soro tratado. Se na prova de soroaglutinação, as amostras, por exemplo, tiveram um título 100 e na de 2mercapto etanol negativas, se tem a indicação de que a classe de imunoglobunas presentes é a de $\operatorname{lgM}$ que pode significar infecção recente ou ainda, reações inespecíficas. Se as duas provas confirmarem o título, é indicativo da presença de IgG, o que sugere um diagnóstico presuntivo de infecção, se houver uma redução parcial do título a níveis baixos da prova de soroaglutinação frente a de 2mercaptoetanol, se aconselha colher nova amostra após um intervalo mínimo de 30 dias. 
ANEXO B - Técnicas de isolamento para leptospirose e brucelose 1

Técnica de isolamento para leptospirose: após colheita da urina, diluir a amostra na proporção 1:10, 1:100, e 1:1000 de solução salina de Soerensen. Cada diluição deve ser efetuada em tubo com antibiótico e meio de cultura Fletcher ou EMJH ágar. Após 24 horas passar para um meio sem antibiótico. As observações serão feitas durante 6 semanas para detectar se houve crescimento, chegando ao título mais provável. Para colheita de fragmento de órgão de animais de apreensão será realizado o mesmo procedimento acima com exceção do uso de antibiótico na cultura com este tipo de amostra (THIERMANN, 1984).

Técnica de isolamento para brucelose: $\mathrm{Na}$ tentativa de isolamento para brucelose o material pode ser sangue total, swab vaginal e órgãos (linfonodo, baço, fígado e órgãos reprodutivos). Na colheita de sangue total o material deve ser diluído em citrato de sódio. Semear em meio de cultura líquido (caldo brucela ou triptose). Incubar em anaerobiose e microaerofilia até 30 dias. A cada 7 dias será realizado o repique em placa e procede a observação. Na colheita através de swab vaginal o material deve ser colocado em meio líquido com antibiótico e realizado PCR de primer gênero específico (detecta Brucella $s p$ ). Se positivo, identificar com primer específico. Na tentativa de isolamento através de fragmentos de órgãos, as amostras de eleição são linfonodos, baço, fígado, órgãos reprodutivos e rim. Nesta metodologia, os fragmentos de órgão vão diretamente para a placa com meio de cultura caldo brucela ou triptose (GREINER et al., 2000) . 
APÊNDICE A- Catetos (Tayassu tajacu) capturados no Parque Estadual Morro do Diabo e fragmentos florestais do Pontal do Paranapanema:

\begin{tabular}{|c|c|c|c|c|c|}
\hline $\begin{array}{l}\text { Código } \\
\text { do } \\
\text { animal }\end{array}$ & Sexo & $\begin{array}{c}\text { Massa } \\
\text { Corporal } \\
\text { (Kg) }\end{array}$ & $\begin{array}{l}\text { Condição } \\
\text { Corporal }\end{array}$ & Faixa Etária & $\begin{array}{l}\text { Local de } \\
\text { captura }\end{array}$ \\
\hline 2 & $M$ & 19 & Proporcional & Adulto & PEMD* \\
\hline 3 & $\mathrm{~F}$ & 9,5 & Proporcional & Filhote 2 & PEMD* \\
\hline 4 & $\mathrm{~F}$ & 21 & Proporcional & Sub adulto & PEMD* \\
\hline 5 & $\mathrm{M}$ & 10 & Proporcional & Filhote 2 & PEMD* \\
\hline 6 & $\mathrm{~F}$ & 22 & Proporcional & Adulto & PEMD* \\
\hline 7 & $\mathrm{M}$ & 19 & Proporcional & Sub adulto & PEMD* \\
\hline 23 & M & 20 & Proporcional & Adulto & PEMD* \\
\hline 24 & $\mathrm{~F}$ & 9 & Proporcional & Filhote 2 & PEMD* \\
\hline 25 & $\mathrm{~F}$ & 22 & Proporcional & Adulto & PEMD* \\
\hline 1 & $\mathrm{~F}$ & 19 & Proporcional & Adulto & Ponte Branca \\
\hline 29 & $\mathrm{M}$ & 13 & Proporcional & Sub adulto & Ponte Branca \\
\hline 32 & $M$ & 9 & Proporcional & Sub adulto & Ponte Branca \\
\hline 33 & $\mathrm{~F}$ & 19 & Proporcional & Adulto & Ponte Branca \\
\hline 34 & $\mathrm{M}$ & 6 & Proporcional & Filhote 2 & Ponte Branca \\
\hline 35 & $\mathrm{~F}$ & 18,5 & Proporcional & Adulto & Ponte Branca \\
\hline 36 & $\mathrm{M}$ & 8,5 & Proporcional & Sub adulto & Ponte Branca \\
\hline 37 & $\mathrm{M}$ & 15 & Proporcional & Adulto & Ponte Branca \\
\hline 151 & $\mathrm{M}$ & 6 & Proporcional & Filhote 1 & Ponte Branca \\
\hline 152 & $\mathrm{~F}$ & 14 & Proporcional & Adulto & Ponte Branca \\
\hline 153 & $\mathrm{~F}$ & 8,5 & Proporcional & Adulto & Ponte Branca \\
\hline 155 & $\mathrm{~F}$ & 17 & Proporcional & Adulto & Ponte Branca \\
\hline- & $\mathrm{F}$ & 8 & Proporcional & Filhote 1 & Ribeirão Bonito \\
\hline 26 & $\mathrm{~F}$ & 10 & Proporcional & Filhote 2 & Ribeirão Bonito \\
\hline 27 & $\mathrm{~F}$ & 19 & Proporcional & Adulto & Ribeirão Bonito \\
\hline 154 & M & 18 & Proporcional & Adulto & Ribeirão Bonito \\
\hline 156 & $\mathrm{M}$ & 8 & Proporcional & Sub adulto & Ribeirão Bonito \\
\hline
\end{tabular}




\begin{tabular}{|c|c|c|c|c|c|}
\hline Brinco & Sexo & $\begin{array}{c}\text { Massa } \\
\text { Corporal } \\
\mathbf{( K g )}\end{array}$ & $\begin{array}{c}\text { Condição } \\
\text { Corporal }\end{array}$ & Faixa Etária & $\begin{array}{c}\text { Local de } \\
\text { captura }\end{array}$ \\
\hline 157 & F & 10 & Proporcional & juvenil & Ribeirão Bonito \\
\hline 158 & M & 11 & Proporcional & Adulto & Ribeirão Bonito \\
\hline 159 & F & 20 & Proporcional & Adulto & Ribeirão Bonito \\
\hline- & F & 4 & Magro & Filhote 1 & Tucano \\
\hline 28 & M & 14 & Proporcional & Adulto & Tucano \\
\hline 30 & M & 10 & Proporcional & Juvenil & Tucano \\
\hline 31 & M & 15 & Proporcional & Adulto & Tucano \\
\hline 160 & M & 7 & Proporcional & juvenil & Tucano \\
\hline 161 & F & 13 & Proporcional & Adulto & Tucano \\
\hline 171 & F & 19,5 & Proporcional & Adulto & Tucano \\
\hline 173 & F & 10 & Proporcional & Filhote 2 & Tucano \\
\hline 172 & M & 22 & Proporcional & Adulto & Santa Zélia \\
\hline 174 & F & 21 & Proporcional & Adulto & Santa Zélia \\
\hline
\end{tabular}


APÊNDICE B- Queixadas (Tayassu peccari) capturados no Parque Estadual Morro do Diabo e Fragmentos florestais:

\begin{tabular}{|c|c|c|c|c|c|}
\hline $\begin{array}{l}\text { Código } \\
\text { do animal }\end{array}$ & Sexo & $\begin{array}{l}\text { Massa } \\
\text { Corporal } \\
(\mathrm{Kg})\end{array}$ & $\begin{array}{l}\text { Condição } \\
\text { Corporal }\end{array}$ & $\begin{array}{l}\text { Faixa } \\
\text { Etária }\end{array}$ & $\begin{array}{l}\text { Local de } \\
\text { captura }\end{array}$ \\
\hline 8 & $\mathrm{~F}$ & 26 & Proporcional & Sub adulto & PEMD* \\
\hline 9 & $F$ & 34 & Proporcional & Adulto & PEMD* \\
\hline 10 & $\mathrm{~F}$ & 26 & Proporcional & Adulto & PEMD* \\
\hline 11 & $\mathrm{~F}$ & 34 & Proporcional & Adulto & PEMD* \\
\hline 12 & $\mathrm{M}$ & 32 & Proporcional & Sub adulto & PEMD* \\
\hline 13 & $\mathrm{M}$ & 30 & Proporcional & Adulto & PEMD* \\
\hline 14 & $\mathrm{M}$ & 31 & Proporcional & Adulto & PEMD* \\
\hline 15 & $\mathrm{~F}$ & 33 & Proporcional & Adulto & PEMD* \\
\hline 16 & $\mathrm{~F}$ & 34 & Proporcional & Adulto & PEMD* \\
\hline 17 & $\mathrm{M}$ & 37 & Proporcional & Adulto & PEMD* \\
\hline 18 & $\mathrm{~F}$ & 26.5 & Proporcional & Adulto & PEMD $^{*}$ \\
\hline 19 & $\mathrm{~F}$ & 29.5 & Proporcional & Adulto & PEMD* \\
\hline 20 & $\mathrm{~F}$ & 30 & Proporcional & Adulto & PEMD* \\
\hline 21 & $\mathrm{~F}$ & 26.5 & Proporcional & Sub adulto & PEMD* \\
\hline 22 & $\mathrm{~F}$ & 26 & Proporcional & Adulto & PEMD* \\
\hline 38 & $\mathrm{~F}$ & 33 & Proporcional & Adulto & PEMD* \\
\hline 39 & $\mathrm{~F}$ & 35 & Proporcional & Adulto & PEMD* \\
\hline 40 & $\mathrm{M}$ & 36 & Proporcional & Adulto & PEMD* \\
\hline 41 & $\mathrm{~F}$ & 39 & Proporcional & Adulto & PEMD* \\
\hline 42 & $\mathrm{~F}$ & 31 & Proporcional & Adulto & PEMD* \\
\hline 43 & $\mathrm{~F}$ & 24 & Proporcional & Sub adulto & PEMD* \\
\hline 44 & $\mathrm{M}$ & 27 & Proporcional & Sub adulto & PEMD* \\
\hline 45 & $\mathrm{~F}$ & 27 & Proporcional & Adulto & PEMD* \\
\hline 46 & $\mathrm{M}$ & 20 & Proporcional & Sub adulto & PEMD* \\
\hline 47 & $\mathrm{~F}$ & 33.5 & Proporcional & Adulto & PEMD* \\
\hline 48 & $\mathrm{~F}$ & 31 & Proporcional & Adulto & PEMD* \\
\hline 49 & $\mathrm{~F}$ & 31 & Proporcional & Adulto & PEMD* $^{*}$ \\
\hline
\end{tabular}




\begin{tabular}{|c|c|c|c|c|c|}
\hline $\begin{array}{l}\text { Código } \\
\text { do animal }\end{array}$ & Sexo & $\begin{array}{l}\text { Massa } \\
\text { Corporal } \\
(\mathrm{Kg})\end{array}$ & $\begin{array}{l}\text { Condição } \\
\text { Corporal }\end{array}$ & $\begin{array}{l}\text { Faixa } \\
\text { Etária }\end{array}$ & $\begin{array}{l}\text { Local de } \\
\text { captura }\end{array}$ \\
\hline 50 & $\mathrm{~F}$ & 28 & Proporcional & Adulto & PEMD* \\
\hline 162 & $M$ & 39 & Proporcional & Adulto & Ponte Branca \\
\hline 163 & $\mathrm{~F}$ & 44 & Proporcional & Adulto & Ponte Branca \\
\hline 165 & $\mathrm{~F}$ & 20 & Proporcional & Sub adulto & Ponte Branca \\
\hline 166 & $\mathrm{~F}$ & 12 & Proporcional & Filhote 2 & Ponte Branca \\
\hline 167 & $\mathrm{~F}$ & 23 & Proporcional & Sub adulto & Ponte Branca \\
\hline 168 & $\mathrm{~F}$ & 20 & Proporcional & Sub adulto & Ponte Branca \\
\hline 169 & $\mathrm{~F}$ & 40 & Proporcional & Adulto & Ponte Branca \\
\hline 170 & $\mathrm{~F}$ & 21 & Proporcional & Adulto & Ponte Branca \\
\hline 175 & $\mathrm{~F}$ & 36 & Proporcional & Adulto & Ponte Branca \\
\hline 281 & M & 22 & Proporcional & Juvenil & Ponte Branca \\
\hline 282 & $\mathrm{~F}$ & 40 & Proporcional & Adulto & Ponte Branca \\
\hline 283 & $M$ & 33 & Proporcional & Adulto & Ponte Branca \\
\hline F1 & $\mathrm{F}$ & 4 & Proporcional & Filhote 1 & Ponte Branca \\
\hline F2 & $\mathrm{F}$ & 4 & Proporcional & Filhote 1 & Ponte Branca \\
\hline 164 & $\mathrm{~F}$ & 40 & OBESO & Adulto & Ponte Branca \\
\hline 288 & $\mathrm{~F}$ & 34 & Proporcional & Adulto & Santa Monica \\
\hline 289 & $\mathrm{M}$ & 34 & Proporcional & Adulto & Santa Monica \\
\hline 290 & $\mathrm{~F}$ & 37 & Proporcional & Adulto & Santa Monica \\
\hline 285 & $\mathrm{M}$ & 19 & Proporcional & Juvenil & Santa Monica \\
\hline 293 & $\mathrm{~F}$ & 29 & Proporcional & Adulto & Santa Monica \\
\hline 284 & $\mathrm{~F}$ & 35 & Proporcional & Adulto & Santa Monica \\
\hline 292 & $\mathrm{M}$ & 39 & Proporcional & Adulto & Santa Monica \\
\hline 286 & M & 20 & Proporcional & subadulto & Santa Monica \\
\hline 291 & $\mathrm{M}$ & 14 & Proporcional & subadulto & Santa Monica \\
\hline Filhote A & $\mathrm{F}$ & 4 & Proporcional & Filhote 1 & Santa Monica \\
\hline Filhote B & $\mathrm{M}$ & 4 & Proporcional & Filhote 1 & Santa Monica \\
\hline Filhote C & $\mathrm{M}$ & 4.5 & Proporcional & Filhote 1 & Santa Monica \\
\hline Filhote D & $\mathrm{F}$ & 7 & Proporcional & Filhote 2 & Santa Monica \\
\hline Filhote E & $\mathrm{M}$ & 6 & Proporcional & Filhote 1 & Santa Monica \\
\hline
\end{tabular}




\begin{tabular}{|l|l|l|l|l|l|}
\hline $\begin{array}{l}\text { Código } \\
\text { do animal }\end{array}$ & Sexo & $\begin{array}{l}\text { Massa } \\
\text { Corporal } \\
\mathbf{( K g )}\end{array}$ & $\begin{array}{l}\text { Condição } \\
\text { Corporal }\end{array}$ & $\begin{array}{l}\text { Faixa } \\
\text { Etária }\end{array}$ & $\begin{array}{l}\text { Local de } \\
\text { captura }\end{array}$ \\
\hline Filhote F & M & 7 & Proporcional & Filhote 1 & Santa Monica \\
\hline 296 & $\mathrm{M}$ & 20 & Proporcional & Filhote 2 & Santa Monica \\
\hline 294 & $\mathrm{M}$ & 15 & Proporcional & Filhote 2 & Santa Monica \\
\hline 287 recap & $\mathrm{F}$ & 32 & Proporcional & Adulto & Santa Monica \\
\hline
\end{tabular}


APÊNDICE C- Ectoparasitas encontrados em catetos (Tayassu tajacu) capturados no Parque Estadual Morro do Diabo e fragmentos florestais do Pontal do Paranapanema:

\begin{tabular}{|c|c|c|c|}
\hline $\begin{array}{l}\text { Código } \\
\text { do animal }\end{array}$ & Ectoparasitas & Faixa Etária & Local de Captura \\
\hline 02 & 0 & Adulto & PEMD* \\
\hline 03 & 0 & Filhote 2 & PEMD* \\
\hline 04 & 0 & Sub adulto & PEMD* \\
\hline 05 & 0 & Filhote 2 & PEMD* \\
\hline 06 & 0 & Adulto & PEMD* \\
\hline 07 & 0 & Sub adulto & PEMD* \\
\hline 23 & $\begin{array}{c}\text { 1M de Amblyomma } \\
\text { cajennense } \\
1 \mathrm{~F} \text { de Amblyomma } \\
\text { naponense } \\
3 \mathrm{~N} \text { de Amblyomma sp }\end{array}$ & Adulto & PEMD* \\
\hline 24 & 0 & Filhote 2 & PEMD* \\
\hline 25 & 0 & Adulto & PEMD* \\
\hline 1 & $\begin{array}{l}\text { 2F de Amblyomma } \\
\text { cajennense } \\
\text { Pnt Branca } 1 \mathrm{M} \text { e } 1 \mathrm{~F} \text { de } \\
\text { Amblyomma naponense }\end{array}$ & Adulto & Ponte Branca \\
\hline 29 & $\begin{array}{l}\text { 4M e 1F de Amblyomma } \\
\text { cajennense } \\
\text { 1F e } 1 \mathrm{M} \text { de Amblyomma } \\
\text { cajennense } \\
\text { 1F e } 1 \mathrm{M} \text { de Amblyomma } \\
\text { naponense } \\
3 \mathrm{~N} \text { de Amblyomma sp }\end{array}$ & Sub adulto & Ponte Branca \\
\hline 32 & $\begin{array}{c}\text { 1F de Amblyomma } \\
\text { cajennense } \\
\text { 3M e 2F de Amblyomma } \\
\text { cajennense }\end{array}$ & Filhote 1 & Ponte Branca \\
\hline
\end{tabular}




\begin{tabular}{|c|c|c|c|}
\hline & 2N de Amblyomma sp & & \\
\hline 33 & $\begin{array}{c}\text { 1F e 1M de Amblyomma } \\
\text { cajennense } \\
\text { 1F de Amblyomma } \\
\text { naponense } \\
\text { 1L de Amblyomma sp }\end{array}$ & Adulto & Ponte Branca \\
\hline 34 & $\begin{array}{c}\text { 1M de Amblyomma } \\
\text { cajennense } \\
\text { Pnt Branca 1F de } \\
\text { Amblyomma naponense }\end{array}$ & Filhote 2 & Ponte Branca \\
\hline 35 & $\begin{array}{c}\text { 5F e 2M de Amblyomma } \\
\text { cajennense } \\
\text { 1F de Amblyomma } \\
\text { naponense }\end{array}$ & Adulto & Ponte Branca \\
\hline 36 & $\begin{array}{c}\text { 1F e 1M de Amblyomma } \\
\text { cajennense }\end{array}$ & Sub adulto & Ponte Branca \\
\hline 37 & $\begin{array}{c}\text { 1M e 1F de Amblyomma } \\
\text { cajennense } \\
\text { 1F de Amblyomma } \\
\text { naponense } \\
\text { 1N de Amblyomma } \\
\text { coelebs }\end{array}$ & Adulto & Ponte Branca \\
\hline 151 & $\begin{array}{c}1 \mathrm{Ne} 1 \mathrm{~F} \text { de Amblyomma } \\
\text { cajennense }\end{array}$ & Filhote 1 & Ponte Branca \\
\hline 152 & $\begin{array}{c}\text { 4F de Amblyomma } \\
\text { cajennense }\end{array}$ & Adulto & Ponte Branca \\
\hline 153 & $5 \mathrm{~N}$ de $A m b l y o m m a \mathrm{sp}$ & Adulto & Ponte Branca \\
\hline 155 & $3 \mathrm{~N}$ e $2 \mathrm{~L}$ de Amblyomma sp & Adulto & Ponte Branca \\
\hline - & $\begin{array}{c}2 \mathrm{~F} \mathrm{e} 1 \mathrm{~N} \text { de Amblyomma } \\
\text { naponense }\end{array}$ & Filhote 1 & Ribeirão Bonito \\
\hline 26 & 0 & Filhote 2 & Ribeirão Bonito \\
\hline 27 & 0 & Adulto & Ribeirão Bonito \\
\hline 154 & 0 & Adulto & Ribeirão Bonito \\
\hline
\end{tabular}




\begin{tabular}{|c|c|c|c|}
\hline 156 & 0 & Sub adulto & Ribeirão Bonito \\
\hline 157 & 0 & juvenil & Ribeirão Bonito \\
\hline 158 & 0 & Adulto & Ribeirão Bonito \\
\hline 159 & 0 & Adulto & Ribeirão Bonito \\
\hline- & $\begin{array}{l}\text { 1F e1M de Amblyomma } \\
\text { naponense } \\
2 \mathrm{~N} \text { de Amblyomma sp }\end{array}$ & Filhote 1 & Tucano \\
\hline 28 & $\begin{array}{c}\text { 1F de Amblyomma } \\
\text { naponense } \\
\text { 1M de Amblyomma } \\
\text { cajennense }\end{array}$ & Adulto & Tucano \\
\hline 30 & $\begin{array}{c}\text { 2M e } 2 \mathrm{~F} \text { de Amblyomma } \\
\text { naponense } \\
\text { 1F de Amblyomma } \\
\text { cajennense } \\
1 \mathrm{~N} \text { e } 1 \mathrm{~L} \text { de Amblyomma sp }\end{array}$ & Juvenil & Tucano \\
\hline 31 & $\begin{array}{c}\text { 4F de Amblyomma } \\
\text { naponense }\end{array}$ & Adulto & Tucano \\
\hline 160 & 2N e $1 \mathrm{~L}$ de Amblyomma sp & Filhote 2 & Tucano \\
\hline 161 & $1 \mathrm{~N}$ de Amblyomma sp & Adulto & Tucano \\
\hline 171 & 0 & Adulto & Tucano \\
\hline 173 & 0 & Filhote 2 & Tucano \\
\hline 172 & 0 & Adulto & Santa Zélia \\
\hline 174 & 0 & Adulto & Santa Zélia \\
\hline
\end{tabular}


APÊNDICE D- Ectoparasitas encontrados em queixadas (Tayassu pecari) capturados no Parque Estadual Morro do Diabo e fragmentos florestais do Pontal do Paranapanema:

\begin{tabular}{|c|c|c|c|}
\hline $\begin{array}{l}\text { Código do } \\
\text { animal }\end{array}$ & Ectoparasita & Faixa Etária & Local de captura \\
\hline 008 & 0 & Sub adulto & PEMD* \\
\hline 009 & 0 & Adulto & PEMD* \\
\hline 010 & 0 & Adulto & PEMD* \\
\hline 011 & 0 & Adulto & PEMD* \\
\hline 012 & 0 & Sub adulto & PEMD* \\
\hline 013 & 0 & Adulto & PEMD* \\
\hline 014 & 0 & Adulto & PEMD* \\
\hline 015 & 0 & Adulto & PEMD* \\
\hline 016 & 0 & Adulto & PEMD* \\
\hline 017 & 0 & Adulto & PEMD* \\
\hline 018 & 0 & Adulto & PEMD* \\
\hline 019 & 0 & Adulto & PEMD* \\
\hline 020 & 0 & Adulto & PEMD* \\
\hline 021 & 0 & Sub adulto & PEMD* \\
\hline 022 & 0 & Adulto & PEMD* \\
\hline 038 & $\begin{array}{l}4 \quad \text { ninfas de } \\
\text { Amblyomma } \\
\text { cajennense }\end{array}$ & Adulto & PEMD* \\
\hline 039 & $\begin{array}{l}1 \text { fêmea de } \\
\text { Amblyomma } \\
\text { naponense }\end{array}$ & Adulto & PEMD* \\
\hline 040 & $\begin{array}{l}2 \text { fêmeas de } \\
\text { Amblyomma } \\
\text { naponense }\end{array}$ & Adulto & PEMD* \\
\hline 041 & $\begin{array}{l}1 \text { macho de } \\
\text { Amblyomma } \\
\text { naponense }\end{array}$ & Adulto & PEMD* \\
\hline
\end{tabular}




\begin{tabular}{|c|c|c|c|}
\hline & $\begin{array}{l}4 \text { ninfas de } \\
\text { Amblyomma } \\
\text { cajenense }\end{array}$ & & \\
\hline 042 & $\begin{array}{l}1 \text { fêmea de } \\
\text { Amblyomma } \\
\text { naponense }\end{array}$ & Adulto & PEMD* \\
\hline 043 & $\begin{array}{l}1 \text { macho e } 1 \\
\text { ninfa de de } \\
\text { Amblyomma } \\
\text { cajennense }\end{array}$ & Sub adulto & PEMD \\
\hline 044 & $\begin{array}{l}3 \text { fêmeas de } \\
\text { Amblyomma } \\
\text { naponense }\end{array}$ & Sub adulto & PEMD* \\
\hline 045 & $\begin{array}{l}5 \quad \text { ninfas de } \\
\text { Amblyomma } \\
\text { cajennense } \\
1\end{array}$ & Adulto & PEMD* \\
\hline 046 & 0 & Sub adulto & PEMD* \\
\hline 047 & 0 & Adulto & PEMD* \\
\hline 048 & 0 & Adulto & PEMD* \\
\hline 049 & 0 & Adulto & PEMD* \\
\hline 050 & 0 & Adulto & PEMD* \\
\hline 162 & 0 & Adulto & Ponte Branca \\
\hline 163 & 0 & Adulto & Ponte Branca \\
\hline 165 & 0 & Sub adulto & Ponte Branca \\
\hline 166 & 0 & Filhote 2 & Ponte Branca \\
\hline 167 & 0 & Sub adulto & Ponte Branca \\
\hline 168 & 0 & Sub adulto & Ponte Branca \\
\hline 169 & 0 & Adulto & Ponte Branca \\
\hline 170 & 0 & Adulto & Ponte Branca \\
\hline 175 & 0 & Adulto & Ponte Branca \\
\hline 281 & 0 & Juvenil & Ponte Branca \\
\hline 282 & 0 & Adulto & Ponte Branca \\
\hline
\end{tabular}




\begin{tabular}{|c|c|c|c|}
\hline 283 & 0 & Adulto & Ponte Branca \\
\hline F1 & 0 & Filhote 1 & Ponte Branca \\
\hline $\mathrm{F} 2$ & 0 & Filhote 1 & Ponte Branca \\
\hline 164 & 0 & Adulto & Ponte Branca \\
\hline 287 & 0 & Adulto & Santa Monica \\
\hline 288 & 0 & Adulto & Santa Monica \\
\hline 289 & 0 & Adulto & Santa Monica \\
\hline 290 & 0 & Adulto & Santa Monica \\
\hline 285 & 0 & Adulto & Santa Monica \\
\hline 293 & 0 & Adulto & Santa Monica \\
\hline 284 & 0 & Adulto & Santa Monica \\
\hline 292 & 0 & Adulto & Santa Monica \\
\hline 286 & 0 & subadulto & Santa Monica \\
\hline 291 & 0 & subadulto & Santa Monica \\
\hline Filhote A & 0 & Filhote 1 & Santa Monica \\
\hline Filhote B & 0 & Filhote 1 & Santa Monica \\
\hline Filhote C & 0 & Filhote 1 & Santa Monica \\
\hline Filhote D & 0 & Filhote 1 & Santa Monica \\
\hline Filhote E & 0 & Filhote 1 & Santa Monica \\
\hline Filhote F & 0 & Filhote 1 & Santa Monica \\
\hline 296 & 0 & Filhote 2 & Santa Monica \\
\hline 294 & 0 & Filhote 2 & Santa Monica \\
\hline 287recap & 0 & Adulto & Santa Monica \\
\hline
\end{tabular}


APÊNDICE E - Propriedades amostradas no estudo:

\begin{tabular}{|c|c|c|}
\hline Fragmento vizinho & Nome da propriedade & Proprietário \\
\hline $\begin{array}{l}\text { Estação Ecológica Mico Leão Preto } \\
\text { (fragmento Água Sumida) }\end{array}$ & Água Sumida & 1 \\
\hline $\begin{array}{l}\text { Estação Ecológica Mico Leão Preto } \\
\text { (fragmento Água Sumida) }\end{array}$ & Água Sumida & 2 \\
\hline $\begin{array}{l}\text { Estação Ecológica Mico Leão Preto } \\
\text { (fragmento Água Sumida) }\end{array}$ & Água Sumida & 3 \\
\hline $\begin{array}{l}\text { Estação Ecológica Mico Leão Preto } \\
\text { (fragmento Água Sumida) }\end{array}$ & Água Sumida & 4 \\
\hline $\begin{array}{l}\text { Estação Ecológica Mico Leão Preto } \\
\text { (fragmento Água Sumida) }\end{array}$ & Água Sumida & 5 \\
\hline $\begin{array}{l}\text { Estação Ecológica Mico Leão Preto } \\
\text { (fragmento Água Sumida) }\end{array}$ & Água Sumida & 6 \\
\hline $\begin{array}{l}\text { Estação Ecológica Mico Leão Preto } \\
\text { (fragmento Água Sumida) }\end{array}$ & Água Sumida & 7 \\
\hline $\begin{array}{l}\text { Estação Ecológica Mico Leão Preto } \\
\text { (fragmento Água Sumida) }\end{array}$ & Água Sumida & 8 \\
\hline $\begin{array}{l}\text { Estação Ecológica Mico Leão Preto } \\
\text { (fragmento Ponte Branca) }\end{array}$ & Fazenda Ponte Branca & 9 \\
\hline $\begin{array}{l}\text { Estação Ecológica Mico Leão Preto } \\
\text { (fragmento Tucano) }\end{array}$ & Tucano & 10 \\
\hline $\begin{array}{l}\text { Estação Ecológica Mico Leão Preto } \\
\text { (fragmento Tucano) }\end{array}$ & Tucano & 11 \\
\hline $\begin{array}{l}\text { Estação Ecológica Mico Leão Preto } \\
\text { (fragmento Tucano) }\end{array}$ & Tucano & 12 \\
\hline $\begin{array}{l}\text { Estação Ecológica Mico Leão Preto } \\
\text { (fragmento Tucano) }\end{array}$ & Tucano & 13 \\
\hline $\begin{array}{l}\text { Estação Ecológica Mico Leão Preto } \\
\text { (fragmento Tucano) }\end{array}$ & Tucano & 14 \\
\hline Estação Ecológica Mico Leão Preto & Tucano & 15 \\
\hline
\end{tabular}




\begin{tabular}{|c|c|c|}
\hline (fragmento Tucano) & & \\
\hline $\begin{array}{l}\text { Estação Ecológica Mico Leão Preto } \\
\text { (fragmento Tucano) }\end{array}$ & Tucano & 16 \\
\hline $\begin{array}{l}\text { Estação Ecológica Mico Leão Preto } \\
\text { (fragmento Tucano) }\end{array}$ & Tucano & 17 \\
\hline $\begin{array}{l}\text { Estação Ecológica Mico Leão Preto } \\
\text { (fragmento Tucano) }\end{array}$ & Tucano & 18 \\
\hline $\begin{array}{l}\text { Estação Ecológica Mico Leão Preto } \\
\text { (fragmento Tucano) }\end{array}$ & Tucano & 19 \\
\hline $\begin{array}{l}\text { Estação Ecológica Mico Leão Preto } \\
\text { (fragmento Tucano) }\end{array}$ & Tucano & 20 \\
\hline $\begin{array}{l}\text { Estação Ecológica Mico Leão Preto } \\
\text { (fragmento Tucano) }\end{array}$ & Tucano & 21 \\
\hline $\begin{array}{l}\text { Estação Ecológica Mico Leão Preto } \\
\text { (fragmento Tucano) }\end{array}$ & Tucano & 22 \\
\hline $\begin{array}{l}\text { Estação Ecológica Mico Leão Preto } \\
\text { (fragmento Tucano) }\end{array}$ & Tucano & 23 \\
\hline $\begin{array}{l}\text { Estação Ecológica Mico Leão Preto } \\
\text { (fragmento Tucano) }\end{array}$ & Tucano & 24 \\
\hline $\begin{array}{l}\text { Estação Ecológica Mico Leão Preto } \\
\text { (fragmento Tucano) }\end{array}$ & Tucano & 25 \\
\hline $\begin{array}{l}\text { Estação Ecológica Mico Leão Preto } \\
\text { (fragmento Santa Maria) }\end{array}$ & Santa Maria & 26 \\
\hline $\begin{array}{l}\text { Estação Ecológica Mico Leão Preto } \\
\text { (fragmento Santa Maria) }\end{array}$ & Santa Maria & 27 \\
\hline $\begin{array}{l}\text { Estação Ecológica Mico Leão Preto } \\
\text { (fragmento Santa Maria) }\end{array}$ & Santa Maria & 28 \\
\hline $\begin{array}{l}\text { Estação Ecológica Mico Leão Preto } \\
\text { (fragmento Santa Maria) }\end{array}$ & Santa Maria & 29 \\
\hline $\begin{array}{l}\text { Estação Ecológica Mico Leão Preto } \\
\text { (fragmento Santa Maria) }\end{array}$ & Santa Maria & 30 \\
\hline $\begin{array}{l}\text { Estação Ecológica Mico Leão Preto } \\
\text { (fragmento Santa Maria) }\end{array}$ & Santa Maria & 31 \\
\hline
\end{tabular}




\begin{tabular}{|c|c|c|}
\hline $\begin{array}{l}\text { Estação Ecológica Mico Leão Preto } \\
\text { (fragmento Santa Maria) }\end{array}$ & Santa Maria & 32 \\
\hline $\begin{array}{l}\text { Estação Ecológica Mico Leão Preto } \\
\text { (fragmento Santa Maria) }\end{array}$ & Santa Maria & 33 \\
\hline $\begin{array}{l}\text { Estação Ecológica Mico Leão Preto } \\
\text { (fragmento Santa Maria) }\end{array}$ & Santa Maria & 34 \\
\hline $\begin{array}{l}\text { Estação Ecológica Mico Leão Preto } \\
\text { (fragmento Santa Maria) }\end{array}$ & Santa Maria & 35 \\
\hline $\begin{array}{l}\text { Estação Ecológica Mico Leão Preto } \\
\text { (fragmento Santa Maria) }\end{array}$ & Santa Maria & 36 \\
\hline $\begin{array}{l}\text { Estação Ecológica Mico Leão Preto } \\
\text { (fragmento Santa Maria) }\end{array}$ & Santa Maria & 37 \\
\hline $\begin{array}{l}\text { Estação Ecológica Mico Leão Preto } \\
\text { (fragmento Santa Maria) }\end{array}$ & Santa Maria & 38 \\
\hline $\begin{array}{l}\text { Estação Ecológica Mico Leão Preto } \\
\text { (fragmento Santa Maria) }\end{array}$ & Santa Maria & 39 \\
\hline $\begin{array}{l}\text { Estação Ecológica Mico Leão Preto } \\
\text { (fragmento Santa Maria) }\end{array}$ & Santa Maria & 40 \\
\hline $\begin{array}{l}\text { Estação Ecológica Mico Leão Preto } \\
\text { (fragmento Santa Maria) }\end{array}$ & Santa Maria & 41 \\
\hline $\begin{array}{l}\text { Estação Ecológica Mico Leão Preto } \\
\text { (fragmento Santa Maria) }\end{array}$ & Santa Maria & 42 \\
\hline PEMD (Parque Estadual Morro do Diabo) & Sitio São Pedro & 43 \\
\hline PEMD (Parque Estadual Morro do Diabo) & Chácara Boca da Noite & 44 \\
\hline PEMD (Parque Estadual Morro do Diabo) & Sítio Alvorada & 45 \\
\hline PEMD (Parque Estadual Morro do Diabo) & Lusitana & 46 \\
\hline PEMD (Parque Estadual Morro do Diabo) & s/nome & 47 \\
\hline PEMD (Parque Estadual Morro do Diabo) & s/nome & 48 \\
\hline PEMD (Parque Estadual Morro do Diabo) & Estância N.S ${ }^{a}$ Aparecida & 49 \\
\hline PEMD (Parque Estadual Morro do Diabo) & Sitio & 50 \\
\hline PEMD (Parque Estadual Morro do Diabo) & Sitio Primavera & 51 \\
\hline PEMD (Parque Estadual Morro do Diabo) & Sitio & 52 \\
\hline PEMD (Parque Estadual Morro do Diabo) & Herling & 53 \\
\hline
\end{tabular}




\begin{tabular}{|c|c|c|}
\hline PEMD (Parque Estadual Morro do Diabo) & $\begin{array}{l}\text { Chacara Um Sonho a } \\
\text { Mais }\end{array}$ & 54 \\
\hline PEMD (Parque Estadual Morro do Diabo) & Fazenda São Sebastião & 55 \\
\hline PEMD (Parque Estadual Morro do Diabo) & Fazenda & 56 \\
\hline PEMD (Parque Estadual Morro do Diabo) & Sitio Maravilha & 57 \\
\hline PEMD (Parque Estadual Morro do Diabo) & Fazenda Cacique & 58 \\
\hline PEMD (Parque Estadual Morro do Diabo) & Fazenda Cachoeira & 59 \\
\hline PEMD (Parque Estadual Morro do Diabo) & $\begin{array}{l}\text { Fazenda Nossa } \\
\text { Aparecida }\end{array}$ & 60 \\
\hline PEMD (Parque Estadual Morro do Diabo) & Fazenda Vasconcelos & 61 \\
\hline PEMD (Parque Estadual Morro do Diabo) & Sítio Mihama & 62 \\
\hline PEMD (Parque Estadual Morro do Diabo) & 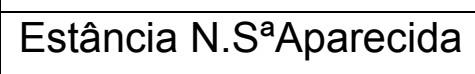 & 63 \\
\hline PEMD (Parque Estadual Morro do Diabo) & Chacara & 64 \\
\hline PEMD (Parque Estadual Morro do Diabo) & $\begin{array}{l}\text { Fazenda Sta Rita de } \\
\text { Cassia }\end{array}$ & 65 \\
\hline PEMD (Parque Estadual Morro do Diabo) & Ribeirão Bonito & 66 \\
\hline PEMD (Parque Estadual Morro do Diabo) & Ribeirão Bonito & 67 \\
\hline PEMD (Parque Estadual Morro do Diabo) & Ribeirão Bonito & 68 \\
\hline PEMD (Parque Estadual Morro do Diabo) & Ribeirão Bonito & 69 \\
\hline PEMD (Parque Estadual Morro do Diabo) & Ribeirão Bonito & 70 \\
\hline PEMD (Parque Estadual Morro do Diabo) & Ribeirão Bonito & 71 \\
\hline PEMD (Parque Estadual Morro do Diabo) & Ribeirão Bonito & 72 \\
\hline PEMD (Parque Estadual Morro do Diabo) & Ribeirão Bonito & 73 \\
\hline PEMD (Parque Estadual Morro do Diabo) & Ribeirão Bonito & 74 \\
\hline PEMD (Parque Estadual Morro do Diabo) & Ribeirão Bonito & 75 \\
\hline PEMD (Parque Estadual Morro do Diabo) & Ribeirão Bonito & 76 \\
\hline PEMD (Parque Estadual Morro do Diabo) & Ribeirão Bonito & 77 \\
\hline PEMD (Parque Estadual Morro do Diabo) & Ribeirão Bonito & 78 \\
\hline PEMD (Parque Estadual Morro do Diabo) & Ribeirão Bonito & 79 \\
\hline PEMD (Parque Estadual Morro do Diabo) & Ribeirão Bonito & 80 \\
\hline PEMD (Parque Estadual Morro do Diabo) & Ribeirão Bonito & 81 \\
\hline PEMD (Parque Estadual Morro do Diabo) & Ribeirão Bonito & 82 \\
\hline PEMD (Parque Estadual Morro do Diabo) & Ribeirão Bonito & 83 \\
\hline
\end{tabular}




\begin{tabular}{|l|l|c|}
\hline PEMD (Parque Estadual Morro do Diabo) & Ribeirão Bonito & 84 \\
\hline PEMD (Parque Estadual Morro do Diabo) & Ribeirão Bonito & 85 \\
\hline PEMD (Parque Estadual Morro do Diabo) & Ribeirão Bonito & 86 \\
\hline PEMD (Parque Estadual Morro do Diabo) & Ribeirão Bonito & 87 \\
\hline PEMD (Parque Estadual Morro do Diabo) & Ribeirão Bonito & 88 \\
\hline PEMD (Parque Estadual Morro do Diabo) & Ribeirão Bonito & 89 \\
\hline Ribeirão & Ribeirão Bonito & 90 \\
\hline Ribeirão & Ribeirão Bonito & 91 \\
\hline Ribeirão & Ribeirão Bonito & 92 \\
\hline Ribeirão & Ribeirão Bonito & 93 \\
\hline Ribeirão & Ribeirão Bonito & 94 \\
\hline Ribeirão & Ribeirão Bonito & 95 \\
\hline Ribeirão & Ribeirão Bonito & 96 \\
\hline Ribeirão & Ribeirão Bonito & 97 \\
\hline Ribeirão & Ribeirão Bonito & 98 \\
\hline Ribeirão & Ribeirão Bonito & 99 \\
\hline Ribeirão & Ribeirão Bonito & 100 \\
\hline Ribeirão & Ribeirão Bonito & 101 \\
\hline Ribeirão & Ribeirão Bonito & 102 \\
\hline Ribeirão & Ribeirão Bonito & 103 \\
\hline Ribeirão & Ribeirão Bonito & 104 \\
\hline Ribeirão & Ribeirão Bonito & 105 \\
\hline Ribeirão & Ribeirão Bonito & 106 \\
\hline Ribeirão & Ribeirão Bonito & 107 \\
\hline Ribeirão & Ribeirão Bonito & 108 \\
\hline Ribeirão & Ribeirão Bonito & 109 \\
\hline Santa Mônica & Fazenda Santa Mônica & 200 \\
\hline Santa Zelia & Santa Zelia & 201 \\
\hline Santa Zelia & Santa Zelia & 202 \\
\hline Santa Zelia & Santa Zelia & 203 \\
\hline Santa Zelia & 205 \\
\hline Santa Zelia & Selia & \\
\hline
\end{tabular}




\begin{tabular}{|l|l|c|}
\hline Santa Zelia & Santa Zelia & 206 \\
\hline Santa Zelia & Santa Zelia & 207 \\
\hline Santa Zelia & Santa Zelia & 208 \\
\hline Santa Zelia & Santa Zelia & 209 \\
\hline Santa Zelia & Santa Zelia & 210 \\
\hline Santa Zelia & Santa Zelia & 211 \\
\hline Santa Zelia & Santa Zelia & 212 \\
\hline Santa Zelia & Santa Zelia & 213 \\
\hline Santa Zelia & Santa Zelia & 214 \\
\hline
\end{tabular}

